\title{
Sequence stratigraphy of the Jurassic of the Danish Central Graben
}

\author{
Jan Andsbjerg and Karen Dybkjær
}

A sequence stratigraphic framework is established for the Jurassic of the Danish Central Graben based primarily on petrophysical log data, core sedimentology and biostratigraphic data from about 50 wells. Regional seismic lines are used to assist in the correlation of some wells and in the construction of isochore maps. In the Lower Jurassic (Hettangian-Pliensbachian) succession, five sequences have been identified. The Middle Jurassic is subdivided into four sequences that together span the uppermost Aalenian/lowermost Bajocian to the Callovian. In the Upper Jurassic, better well coverage permits greater stratigraphic resolution, and 11 sequences are identified and mapped.

On the basis of the sequence stratigraphic correlation and the construction of isochore maps for individual sequences, the Jurassic basin history of the Danish Central Graben can be subdivided into seven discrete phases: (1) Shallow marine and offshore sediments deposited in a prerift basin extending from the North Sea to the Fennoscandian Border Zone (Hettangian-Pliensbachian). (2) Uplift and erosion in association with a Toarcian-Aalenian North Sea doming event. A major hiatus represents this phase in the study area. (3) Terrestrial and marginal marine sedimentation during initial rifting (latest Aalenian/earliest Bajocian - Late Callovian). (4) Early Oxfordian - Early Kimmeridgian transgression during and after a rift pulse. The sedimentary environment changed from coastal plain and marginal marine to fully marine. (5) Regression associated with a cessation or slowing of subsidence during a structural rearrangement that took place in the Late Kimmeridgian during a break in the main rift climax. Shallow to marginal marine sandstones were deposited above an erosion surface of regional extent. (6) Deep-water mudstones deposited in a composite graben with high subsidence rates related to rift pulses (latest Late Kimmeridgian middle Middle Volgian). (7) Deposition of organic-rich mudstones and turbidite sandstones during the late Middle Volgian - Early Ryazanian. The main basin shallowed, became more symmetrical and experienced a decreasing rate of subsidence, recording the onset of the post-rift stage.

A relative sea-level curve is constructed for the Middle-Late Jurassic. It shows close similarity to published eustatic (global) and relative (North Atlantic area) sea-level curves in the latest Bathonian - late Early Kimmeridgian, but differs in the Late Kimmeridgian - Middle Volgian interval, probably due to the high rate of subsidence in the study area.

Keywords: Danish Central Graben, Jurassic, sequence stratigraphy, palaeogeography, basin evolution, sea-level changes

Geological Survey of Denmark and Greenland, Geocenter Copenhagen, Øster Voldgade 10, DK-1350 Copenhagen K, Denmark. E-mail: ja@geus.dk

The Jurassic deposits in the Danish Central Graben are of particular interest in relation to hydrocarbon exploration, as they include units of reservoir sandstones as well as oil- and gas-producing source rocks (Fig. 1).
Hydrocarbon discoveries have been made in both Middle and Upper Jurassic sandstones, and the Middle Jurassic Harald Field is under production. The distribution of both reservoirs and source rocks reflects the complex 
tectonic evolution of the area and a depositional history strongly influenced by relative sea-level changes.

Data from a large number of wells in the study area have been released in recent years, contributing impor- tant new information to this study. The aim of this paper is to present a sequence stratigraphic model for the Jurassic deposits of the Danish Central Graben.

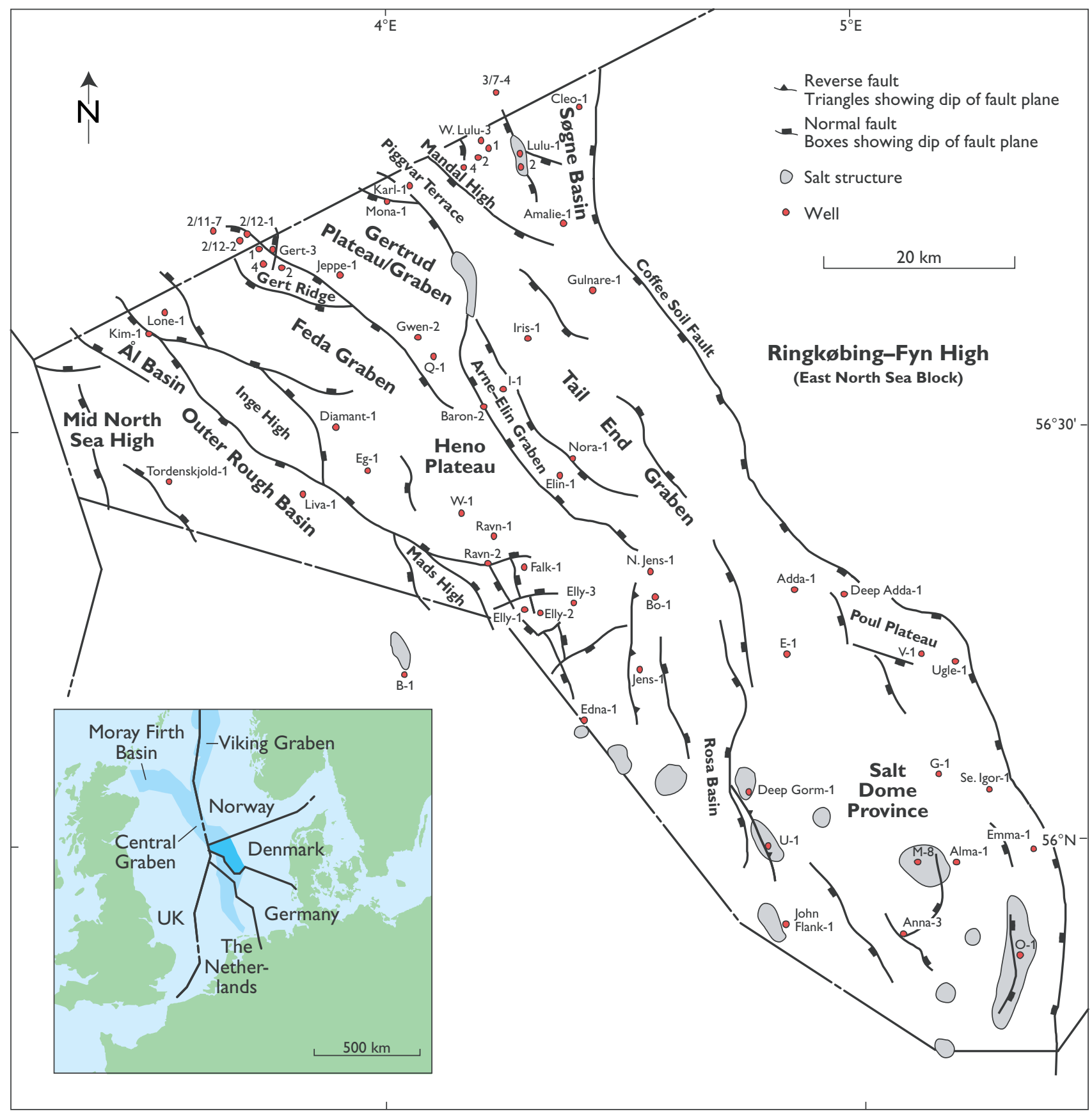

Fig. 1. Maps showing the location of the study area (dark blue) within the Jurassic North Sea rift system, the Jurassic structural elements in the Danish Central Graben and the position of the wells incorporated in the study; note that all wells forming the database for the isochore and palaeogeographic maps are indicated, although some are not specifically mentioned in the text or illustrated. The Middle Jurassic Harald Field is delimited by the location of the West Lulu-1, -2 and -3 wells; note that the structural feature denoted the Gertrud Plateau/Graben is so indicated to reflect the structural evolution of this region in the Late Jurassic, from a positive plateau in the early Late Jurassic to an actively subsiding graben from the Early Volgian. 


\section{Regional geology}

The Central Graben forms the southern part of the North Sea rift system. Active rifting took place in this area both in the Triassic and in the late Middle Jurassic - Late Jurassic (Roberts et al. 1990; Ziegler 1990). The $500 \mathrm{~km}$ long Central Graben, approximately $150 \mathrm{~km}$ of which are situated in the Danish North Sea sector, consists of a NNW-SSE-trending complex of half-grabens, and a subordinate $\mathrm{N}-\mathrm{S}$-trending segment to the south extending into the German and Dutch sectors. The main bounding fault in the Danish sector is the Coffee Soil Fault, which forms the eastern margin of the Danish Central Graben (Fig. 1).

The Early Jurassic was characterised by a slow relative sea-level rise and deposition of marine muds of the Fjerritslev Formation, probably over most of the Danish area (Fig. 2; Larsen 1966; Michelsen 1978, 1989; Pedersen 1986; Michelsen et al. 1987).

In latest Early Jurassic - earliest Middle Jurassic times, the whole area was uplifted and most of the Lower Jurassic section was removed by erosion (Hallam \&
Sellwood 1976; Ziegler 1982, 1990; Underhill \& Partington 1993). The uplift may have occurred in response to the development of a rift dome extending $700 \mathrm{~km}$ in a north-south direction and $1000 \mathrm{~km}$ east-west across the central North Sea (Whiteman et al. 1975; Eynon 1981; Ziegler 1990; Underhill \& Partington 1993). Domal uplift appears to have been accompanied by the development of a volcanic complex at the triple junction between the Viking Graben, the Central Graben and the Moray Firth Basin (Ziegler 1990). Sedimentation resumed in the Danish part of the Central Graben during the Middle Jurassic, with deposition of the sandstone-dominated Bryne and Lulu Formations and the mudstonedominated Middle Graben Formation (Michelsen et al. 2003, this volume). These sediments are restricted to the Søgne Basin, the Tail End Graben and the Salt Dome Province (Vollset \& Doré 1984; Jensen et al. 1986). The first marine transgression in the Danish Central Graben occurred during the Callovian-Oxfordian, probably reflecting the onset of domal collapse combined with eustatic sea-level rise (Ziegler 1990; Underhill \& Partington 1993).
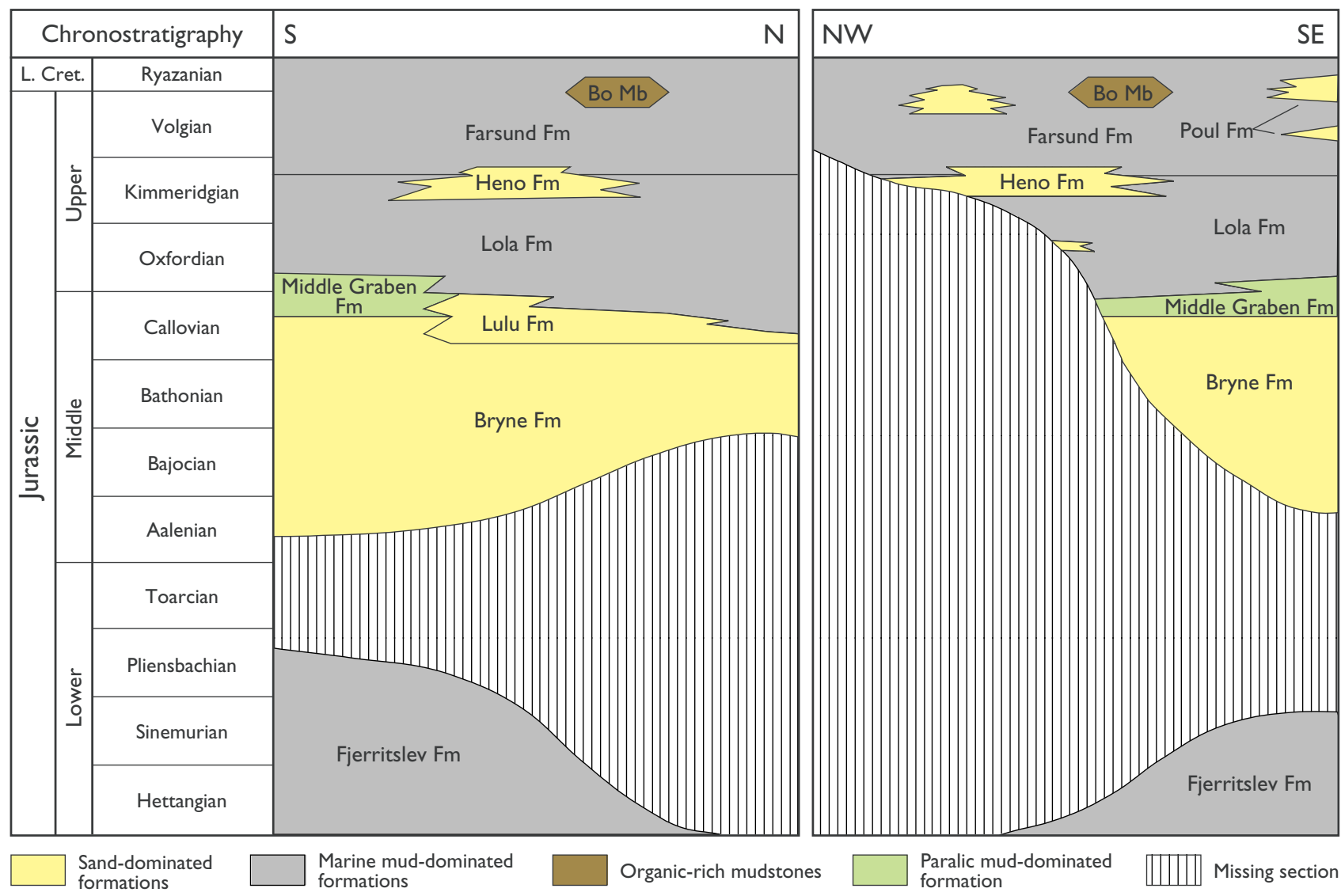

Fig. 2. Jurassic lithostratigraphy of the Danish Central Graben, based on Jensen et al. (1986) and Michelsen et al. (2003, this volume). L. Cret., Lower Cretaceous. 
During Late Jurassic time, the Feda Graben, the Heno Plateau and the Gertrud Graben became actively subsiding depositional basins, and the depositional area was later extended to the Outer Rough and Ål Basins (Fig. 1). Deep-water conditions were established in the Danish Central Graben during the Oxfordian-Kimmeridgian, when the marine mudstones of the Lola Formation were deposited. During the Late Kimmeridgian, shallow marine sandstones of the Heno Formation were deposited on plateau areas. The transgression culminated during the Volgian with deposition of the deep marine mudstones of the Farsund Formation (Vollset \& Doré 1984; Jensen et al. 1986). The Early Cretaceous saw a change to more passive thermal subsidence (Roberts et al. 1990).

In addition to rift tectonics, basin development in the Central Graben was also strongly influenced by the presence of mobile Zechstein salt. Salt movements had a profound influence on the development of depocentres in the Søgne Basin, the Tail End Graben and the Salt Dome Province (Korstgaard et al. 1993; Sundsbø \& Megson 1993).

\section{Stratigraphic methods}

The stratigraphic analysis is based on data from about 50 wells that penetrate Jurassic deposits in the Danish Central Graben, and a few wells from the Norwegian North Sea sector located near the boundary (Fig. 1). Well logs, including gamma-ray, sonic, neutron/density and resistivity logs, sedimentological core logs, lithology logs, and biostratigraphic data were used in the study. Furthermore, a number of interpreted regional seismic lines were included to support the generation of isochore maps.

\section{Biostratigraphy}

The biostratigraphic data used in this study are confined to palynomorphs because information from other groups of microfossils is too scarce in most wells to be useful for detailed correlation. The biostratigraphic correlations are based on events rather than recognition of biozones. The events used in our study are mainly last occurrence datums (i.e. first downhole appearance) of dinoflagellate cyst species (Fig. 3). The biostratigraphic information utilised in the study includes published data (Birkelund et al. 1983; Hoelstad 1986; Poulsen 1986, 1991; Heilmann-Clausen 1987; Johannessen et al. 1996), unpublished reports of the Geological Survey of
Denmark and Greenland and of industrial service companies, and the results of new analyses made specifically for this study.

Due to poor core coverage, being generally restricted to sandy successions of relatively few wells, most data were derived from cuttings samples. Although sample quality in the Lower Jurassic succession was variable, it was possible to establish a palynostratigraphic framework based on a small number of events and stratigraphically diagnostic palyno-assemblages (Fig. 3A). A detailed palynostratigraphical subdivision of the Middle Jurassic succession is precluded by the sparse occurrence of age-diagnostic palynomorphs (Fig. 3B); although scanty, the available records made it possible to give an approximate age for the sequences and major events in the Middle Jurassic. In the Upper Jurassic, the large sediment thicknesses, the somewhat better data quality, the favourable environment, and the higher diversity of dinoflagellate cyst species probably all contribute to a higher biostratigraphic resolution (Fig. 3C).

\section{Sequence stratigraphy}

The sequence stratigraphic terminology applied is that introduced by the Exxon group (Posamentier et al. 1988; Posamentier \& Vail 1988; Van Wagoner et al. 1988, 1990). Sequences are subdivided into lowstand, transgressive and highstand systems tracts. A four-fold subdivision with the addition of the forced regressive systems tract (Hunt \& Tucker 1992, 1995) is not attempted due to the scale of the study and the nature of the data.

Construction of the sequence stratigraphic framework is based on correlation of well log patterns, combined with biostratigraphic datings. The most conspicuous log patterns, supported by the most important biostratigraphic events, were used to produce a coarse grid, within which more detailed correlations were made. Most commonly the gamma-ray logs were used for high-resolution correlations but resistivity logs formed the primary tool in some organic-rich mudstone units. Distinct sonic log markers were occasionally used for correlation. Maximum flooding surfaces (MFS) are considered the most reliable correlation surfaces in successions dominated by marine mudstones, whereas sequence boundaries (SB), and occasionally flooding surfaces (FS), are of primary importance in silty and sandy units. Both SB and MFS key surfaces can normally be traced through most of the basin. In sections dominated by marine mudstones and siltstones, the SB is usually picked at the turnaround point between a coars- 
A

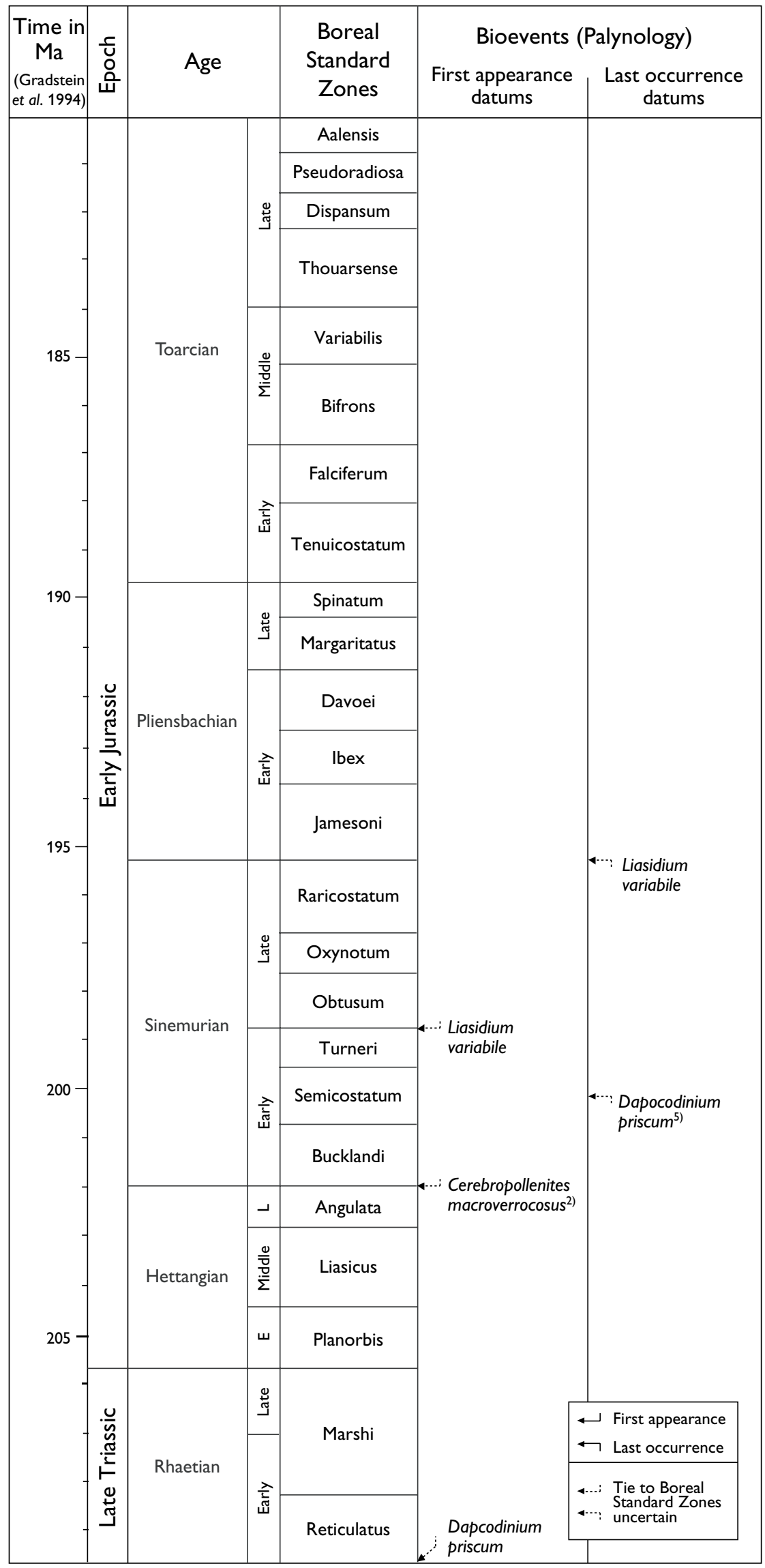

Fig. 3. Bioevents used for dating the sequences in the Lower Jurassic (A), Middle Jurassic (B) and Upper Jurassic - lowermost Cretaceous (C) of the Danish Central Graben. The tie to Boreal Standard Zones are according to Riding \& Thomas (1992), unless otherwise indicated: 1, Fenton \& Riding (1987); 2, Dybkjær (1991); 3, Poulsen (1991); 4, Costa \& Davey (1992); 5, Poulsen (1992); 6, Poulsen \& Riding (2003, this volume).

Note in Fig. 3C: (1) The species indicated with an asterisk (Muderongia simplex) was previously referred to Muderongia sp. A Davey 1979; see further discussion in Poulsen (1996).

(2) Although the LOD is indicated at the base of the Kerberus Zone, the species Senoniasphaera jurassica (double asterisk) may occur sporadically up to the Anguiformis Zone. E, Early; L, Late. 


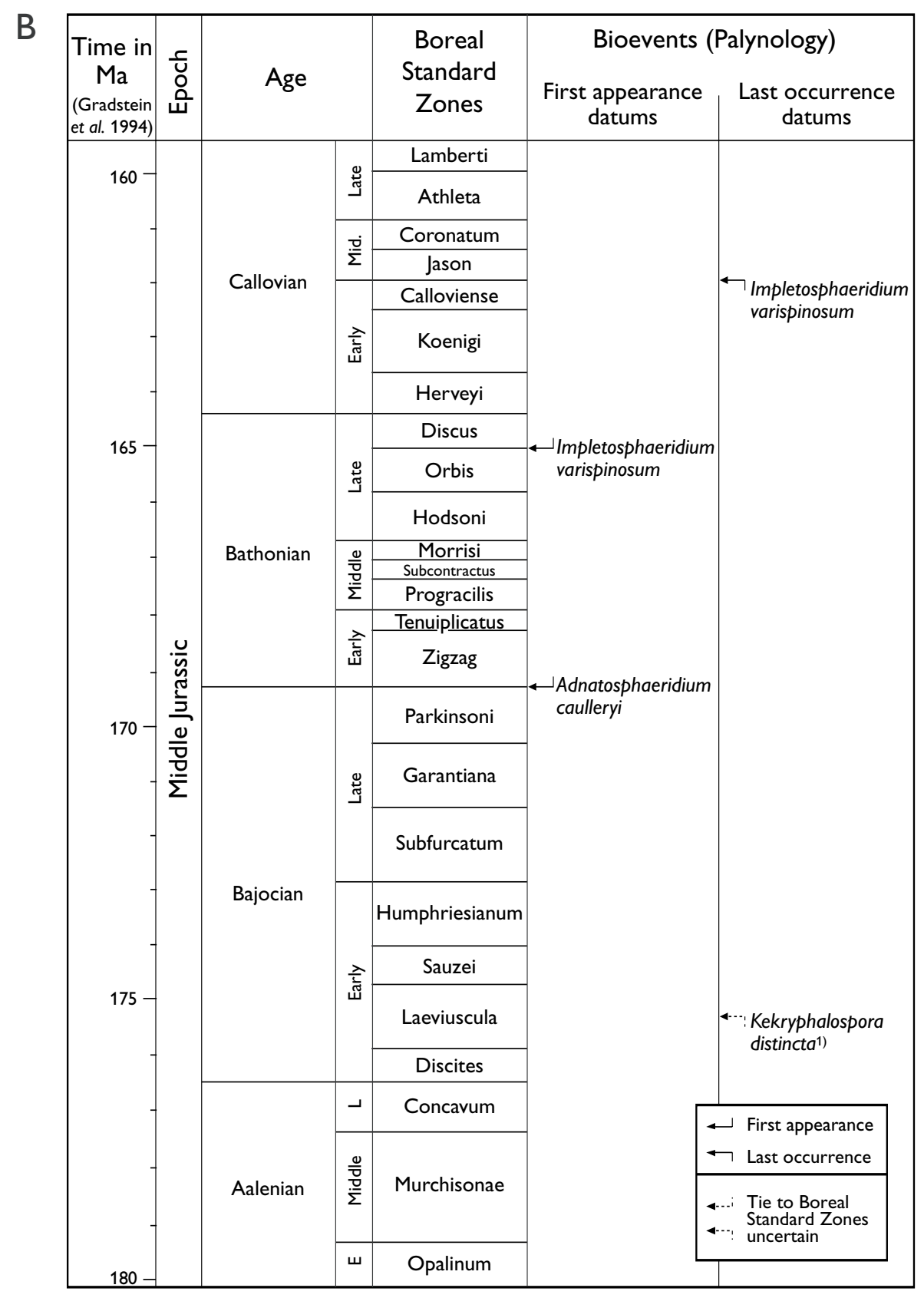

ening-upwards unit and a fining-upwards unit, or at the sharp base of a relatively coarse-grained bed occupying the position of the turnaround point.

Well logs form the primary tool for the identification of lithologies, sedimentary facies and sedimentary successions, and thus for the identification of key surfaces and systems tracts. The cored sections have been the subject of more detailed sedimentological facies analysis and palynofacies investigations (Hoelstad 1986; Johannessen \& Andsbjerg 1993; Johannessen et al. 1996; Andsbjerg 2003, this volume; Ineson et al. 2003, this volume; Johannessen 2003, this volume); these results have been used to support the sequence stratigraphic subdivision.
The Lower Jurassic succession shows laterally consistent log patterns and, where a unit has not been removed by erosion, correlation of key surfaces is possible over wide areas. In the Middle Jurassic section, only two or three key surfaces can be correlated from one subbasin to another. A more detailed, four-fold sequence subdivision of the Middle Jurassic deposits within the Søgne Basin is presented by Andsbjerg (2003, this volume). The laterally uniform log patterns of most of the Upper Jurassic succession allow detailed well correlations. In addition to the gamma-ray log, the resistivity logs proved to be a robust tool for high-resolution correlations in the Lower Volgian succession of the 


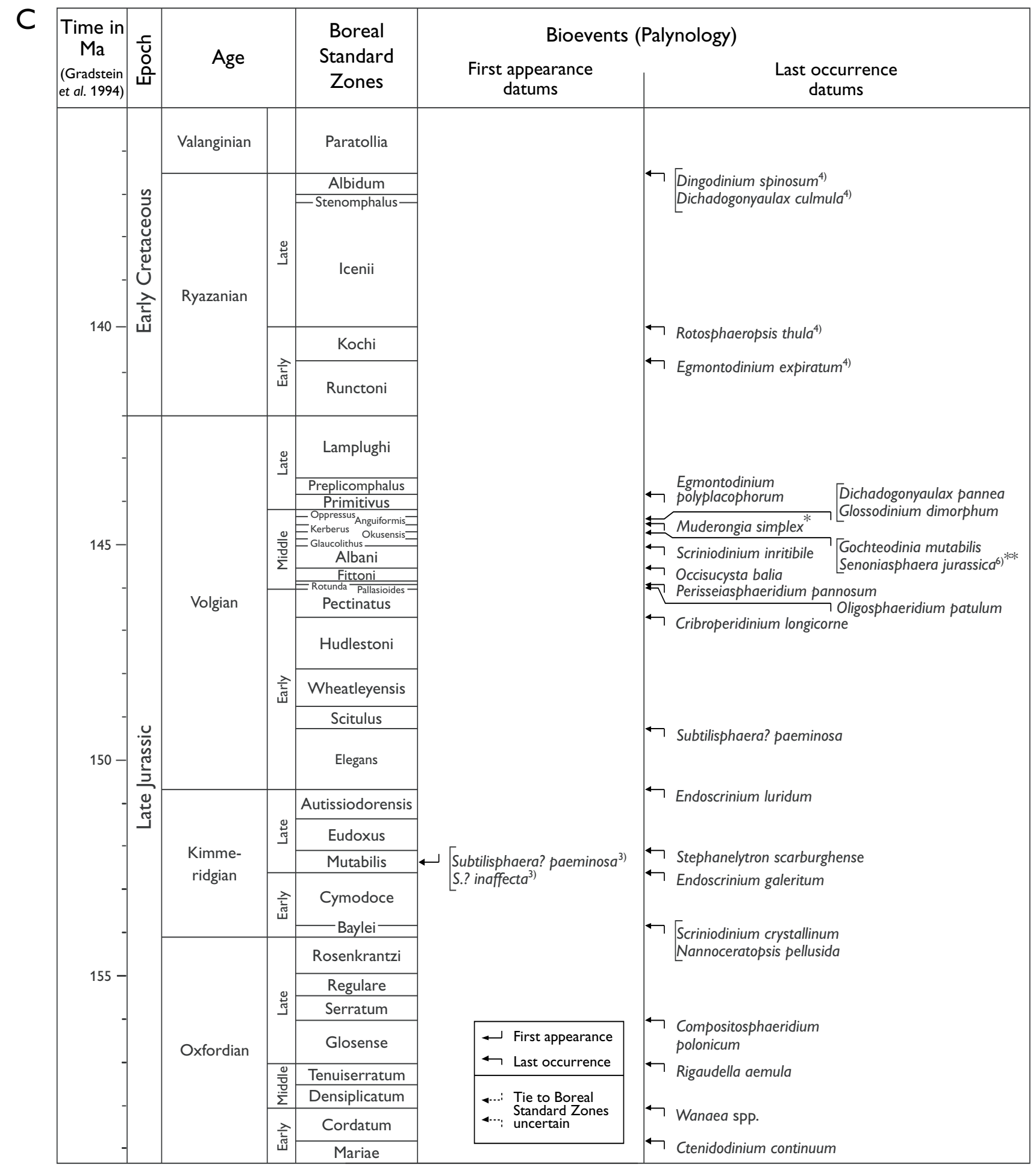

southern Feda Graben and the northernmost Heno Plateau. Most key surfaces in the Upper Jurassic succession are picked in marine mudstones and siltstones. Of these key surfaces, only one sequence boundary (the base Kimm-2 SB) shows any sign of significant erosion.

Unusually high organic contents in the Upper Volgian - Ryazanian mudstones of the Bo Member (Michelsen et al. 2003, this volume) probably influence log responses and impede sequence stratigraphic interpretation (Ineson et al. 2003, this volume). In the uppermost sequence of this study, Ryaz-1, a maximum flooding surface is not identified. It might have been picked at the highest gamma-ray peak in accordance with conventional sequence stratigraphic concepts, but in this case all of 
the Bo Member may form part of the transgressive systems tract as suggested for this type of deposits by Posamentier \& James (1993). This level marks the top of the studied succession. In those wells where the uppermost part of the Farsund Formation is preserved, it is dated as Late Ryazanian.

\section{Sequence stratigraphic subdivision and basin history}

The Jurassic succession in the Danish Central Graben is subdivided into 20 sequences, referred to according to their age (i.e. Hettangian sequences: Hett-1, Hett-2). The main characteristics of each sequence - log expression of sequence boundaries, lithology, thickness, age - are summarised and illustrated below. The lower boundary is described for each sequence, the upper boundary being described under the succeeding sequence. Lithologies in the sequence descriptions have been interpreted primarily on the basis of gamma-ray logs, supported by other log types and by core data when available. In the sandstone-dominated intervals, increasing gamma-ray values are interpreted to reflect finingupwards grain-size trends, and decreasing values to reflect coarsening-upwards trends. In the mudstone successions, changing gamma-ray values are interpreted to reflect changes in clay content; increasing gammaray values are thus interpreted to record increasing clay content and decreasing gamma-ray values to record decreasing clay content. Thin carbonate beds are represented by low-value gamma-ray spikes. Mudstone intervals with exceptionally high gamma-ray values are interpreted as being particularly rich in organic matter. Based on these inferred relationships between gammaray values and lithologies, increasing-upwards gammaray patterns are generally interpreted to be characteristic of the transgressive systems tract (TST) and decreasingupwards gamma-ray patterns of the highstand systems tract (HST). The maximum flooding surface (MFS) is picked at the turnaround point where gamma-ray values are at a maximum between the increasing gammaray values of the TST below and decreasing gamma-ray values of the HST unit above.

The identified sequences are of approximately the same order of thickness. Due to variations in subsidence rate, the duration of the sequences recognised in the Lower and Middle Jurassic is somewhat longer than for the Upper Jurassic sequences. All sequences, however, probably correspond to 3rd order sequences as defined by Vail et al. (1977) and Van Wagoner et al. (1990).
The evolution of the Danish Central Graben can be considered in terms of seven depositional phases on the basis of the subdivision of the Jurassic deposits into sequences and systems tracts. The significant influence of tectonics on depositional patterns in rift settings has been demonstrated by a number of studies (Surlyk \& Clemmensen 1983; Rosendahl 1987; Gabrielsen et al. 1990; Prosser 1993; Nøttvedt et al. 1995). However, we have attempted to relate the development of the depositional phases to the effects of both tectonics and eustasy.

The nomenclature and subdivision of rifting phases introduced by Prosser (1993) and adapted by Nøttvedt et al. (1995) are used in an attempt to relate the depositional phases of the present study to rifting stages. The proto-rift stage is characterised by flexural subsidence and interrupted by domal uplift. The subsequent rift stage is subdivided into rift initiation and rift climax: rift initiation is associated with fault block compartmentalisation and weak tilting whereas the rift climax is characterised by the maximum rate of fault displacement and strong tilting. The early post-rift stage is marked by the cessation of significant activity at the main faults and a declining rate of regional subsidence. It should be appreciated, however, that the three stage model of Nøttvedt et al. (1995) refers to the evolution of rift basins in general. In the present study, the model has been applied to minor basins in a large rift structure and the evolution of these basins may not be representative of the rift structure as a whole. This is emphasised by the diachronous onset of subsidence in neighbouring basins, as described below.

In the present study, several pulses of active faulting are inferred to have taken place between the initiation of the Middle Jurassic rift stage and the Early Cretaceous early post-rift stage. We have followed Surlyk (1978, 1989) and Blair \& Bilodeau (1988) in correlating overall fining-upwards successions in rift basins with periods of active tectonic subsidence, and large-scale coarsening-upwards successions with periods of relative tectonic quiescence.

\section{Phase 1. Pre-rift shallow marine deposition (Hettangian-Pliensbachian)}

\section{Sequence definitions}

\section{Hett-1 sequence}

The Hett- 1 sequence is present only in the Deep Gorm-1, M- 8 and U-1 wells; it consists of marine mudstones. The lower sequence 
boundary is located at the change from the low gamma-ray values of the underlying Triassic deposits to the high gamma-ray values, characteristic of the mudstones of the Hett-1 sequence (Figs 4, 5). The boundary may be abrupt or gradational. The thickness of the sequence attains a maximum of $23 \mathrm{~m}$ in $\mathrm{M}-8$.

Stratigraphically useful bioevents have not been recorded from this unit. The sequence is thought to be of Hettangian age due to its stratigraphic position in the lowermost part of the Fjerritslev Formation, unconformably overlying Upper Triassic deposits.

\section{Hett-2 sequence}

The marine mudstones of the Hett- 2 sequence have only been found in six wells but are considered to extend throughout the Salt Dome Province. The boundary between the Hett- 1 and Hett-2 sequences is located at a shift to mudstones characterised by somewhat lower clay contents (Figs 4, 5). In wells where the Hett-2 sequence directly overlies pre-Jurassic sediments (e.g. Edna-1; Fig. 5), the lower sequence boundary is marked by an abrupt lithological shift. The thickness of the sequence shows very little variation, attaining a maximum of $64 \mathrm{~m}$ in Edna-1.

The abundance of bisaccate pollen of Pinuspollenites minimus within this sequence in the Edna-1, John Flank-1 and O-1 wells indicates the presence of the Pinuspollenites-Trachysporites Zone of Lund (1977). This zone is known from the Danish Basin, Skåne and northern Germany and is referred to the Hettangian (Lund 1977; Dybkjær 1991). A Hettangian age is further supported by the occurrence of the dinocyst species Dapcodinium priscum in the wells mentioned above and the absence of the pollen species Cerebropollenites macrovermcosus (Fig. 3A).

\section{Sin-1 sequence}

The marine mudstones of this sequence probably extend throughout the Salt Dome Province. The lower sequence boundary is typically located at a marked shift to mudstones with higher clay contents (Figs 4, 5). The thickness of the sequence attains a maximum of $63 \mathrm{~m}$ in Deep Gorm-1.

The last occurrence datum (LOD) of Dapcodinium priscum in the lower part of the sequence in the O-1 well, and the first appearance datum (FAD) of Cerebropollenites macroverrucosus in core samples from the middle part of the sequence in the Deep Gorm-1 well, indicate a latest Hettangian - Early Sinemurian age for the lower part of the sequence. In combination with the LOD of Liasidium variabile close to the upper boundary of this sequence in $\mathrm{O}-1$, this indicates a latest Hettangian - Sinemurian age for the sequence (Fig. 3A).

\section{Pliens-1 sequence}

This sequence is only present in the Deep Gorm-1 and Edna-1 wells situated in the north-western part of the Salt Dome Province. In both wells, it is represented by marine mudstones. The lower sequence boundary is located at the top of the well-defined coarsening-upwards
HST of the Sin-1 sequence (Figs 4, 5). The thickness of the sequence attains a maximum of $63 \mathrm{~m}$ in Edna-1.

The common occurrence (in sidewall cores) of pollen referred to the genus Chasmasporites indicates the presence of the Chasmasporites Zone (Koppelhus \& Nielsen 1994), defined in the Korsodde section, Bornholm, Denmark. The Chasmasporites Zone is referred to the Pliensbachian, an age assignment supported by the stratigraphic position of this sequence immediately above the LOD of Liasidium variabile. The acme of the small, spherical pollen referred to the genus Spheripollenites, characteristic of the uppermost Pliensbachian - Lower Toarcian deposits in the Danish Basin and known from many other locations in Northwest Europe (Dybkjær 1991), has not been reported from the Danish Central Graben. This may indicate that deposits of latest Pliensbachian - Toarcian age are absent in the study area.

\section{Pliens-2 sequence}

The marine mudstones of this sequence have only been recognised in the Deep Gorm-1 and Edna-1 wells (Fig. 4). The sequence boundary is positioned where the lithology changes abruptly from silty mudstones of the Pliens-1 HST to more clay-rich mudstones (Fig. 5). In the Deep Gorm-1 well, the sequence is represented by less than $10 \mathrm{~m}$ of clay-rich mudstone; in Edna-1, the sequence attains a thickness of $62 \mathrm{~m}$

The common occurrence (in sidewall cores) of Chasmasporites sp. pollen in Edna-1 and the absence of a Spheripollenites sp. acme and of other Toarcian bioevents (such as the FAD of the spore genera Leptolepidites, Ischyosporites, Manumia or Staplinisporites), indicate a Pliensbachian age for this sequence.

\section{Basin evolution}

The Early Jurassic was a tectonically quiescent period between phases of active rifting in the Triassic and in the Middle-Late Jurassic (Cartwright 1991; Nøttvedt et al. 1995). A eustatic rise in sea level during the Early Jurassic was proposed by Hallam (1981) and Haq et al. (1988), compatible with observations from the Danish Basin (Michelsen 1978, 1989; Pedersen 1986; Dybkjær 1988, 1991). Uniform lithologies, dominated by shelf mudstones, indicate that marine conditions existed across a major North Sea basin and extended into the Danish Basin (Michelsen 1978, 1982, 1989; Michelsen et al. 1987; Pedersen 1985; Nielsen 2003, this volume).

The Lower Jurassic marine mudstones within the study area have only been found in the Salt Dome Province. They were probably deposited over a wider area, but were removed by erosion during the regional uplift phase (phase 2) at the Early-Middle Jurassic transition (Andersen et al. 1982; Gowers \& Sæbøe 1985; Underhill \& Partington 1993). The extent of Lower 


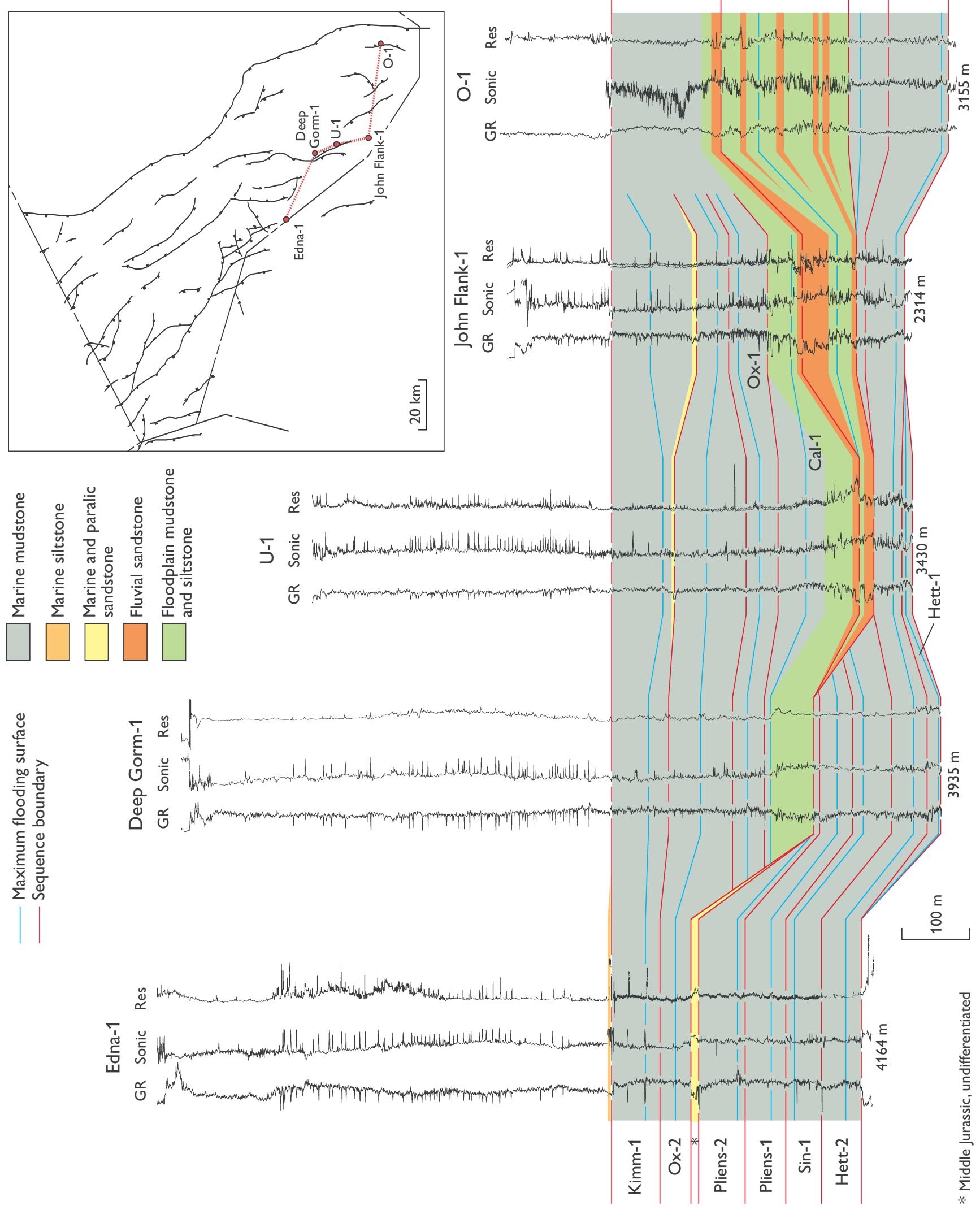



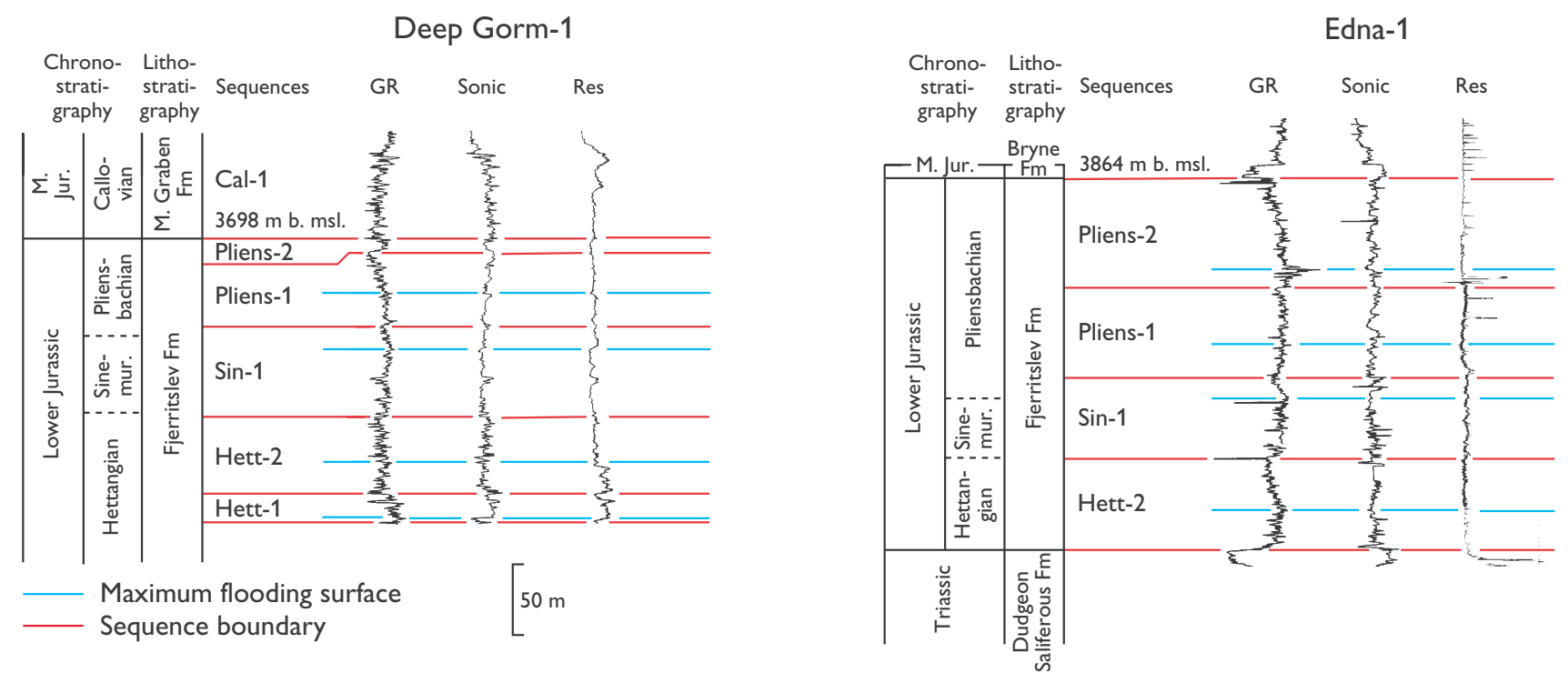

Fig. 5. Lower Jurassic sequences (Hett-1 - Pliens-1) in the Deep Gorm-1 and Edna-1 wells. For reference purposes, the depth (in metres below mean sea level) is indicated for a selected sequence boundary, typically in the upper levels of the illustrated section (see also Figs 6, 10, 12, 19, 22). Jur., Jurassic; M., Middle; Sinemur., Sinemurian.

Jurassic deposits in the deepest parts of the Tail End Graben and the Søgne Basin is unknown due to the lack of wells penetrating the base of the Middle Jurassic in these areas.

Five transgressive-regressive cycles, corresponding to the Hett-1 - Pliens-2 sequences are identified in the Lower Jurassic succession (e.g. Deep Gorm-1, Edna-1; Fig. 4). Individual sequences show a remarkable lateral consistency in thickness (Fig. 4), indicating a uniform subsidence history in the study area during most of the Early Jurassic.

\section{Facing page:}

Fig. 4. Sequence stratigraphic correlation of the Lower, Middle and lowermost Upper Jurassic in the Salt Dome Province. The Lower Jurassic succession is truncated by an unconformity at the base of the Middle Jurassic. The depth given beneath each well in this and subsequent correlation panels indicates the depth of the lowermost tieline (typically base-Jurassic section) below well reference level; for those few wells that did not penetrate the Jurassic section, the depth indicates the base of the logged section (i.e. well total depth). The log suite utilised in the study and illustrated in this and subsequent figures includes gamma-ray (GR), sonic velocity (Sonic) and resistivity (Res) logs.

\section{Phase 2. Uplift and erosion in the proto-rift phase (latest Pliensbachian - latest Aalenian)}

\section{Basin evolution}

A major unconformity separates Lower Jurassic deposits from the overlying Middle and Upper Jurassic deposits over much of the North Sea area. It has been suggested that this unconformity was caused by domal uplift in the Toarcian to Aalenian, centred at the triple junction between the Viking Graben, the Moray Firth Basin and the Central Graben (Whiteman et al. 1975; Hallam \& Sellwood 1976; Eynon 1981; Ziegler 1982; Underhill \& Partington 1993). The unconformity may therefore be an example of a proto-rift unconformity, described by Nøttvedt et al. (1995) as being typical of rift systems with thermally-induced domal uplift before or at the onset of active stretching.

As a result of the regional uplift, most of the Lower Jurassic deposits were removed. In the southern part of the Danish Central Graben, where Lower Jurassic deposits are preserved, differential erosion of the upper part of the succession may be due to local salt tectonics. Regional erosion caused a larger part of the succession to be removed over the top of the salt structures. The full Lower Jurassic succession shows thickness variations from about $60 \mathrm{~m}$ in U-1 to about $260 \mathrm{~m}$ in Edna-1 (Fig. 4).

Reworked Lower Jurassic palynomorphs recorded from the Upper Kimmeridgian sandstones of the Heno 
Formation in the northern part of the Danish Central Graben (Gwen-2; Johannessen et al. 1996) supports the assumption that Lower Jurassic deposits were significantly more extensive prior to mid-Jurassic erosion.

\section{Phase 3. Terrestrial and marginal marine deposition during the rift initiation stage (latest Aalenian/earliest Bajocian - Late Callovian)}

\section{Sequence definitions}

\section{Aalen-1 sequence}

This sequence is encountered in most wells drilled in the Søgne Basin and in the Nora-1 well in the Tail End Graben (Figs 6, 7). It lies unconformably on either pre-Jurassic or Lower Jurassic deposits. The TST dominates the sequence and consists of a number of minor, backstepping, fining-upwards sandstone intervals, interpreted as stacked fluvial channels, with subordinate floodplain or lacustrine mudstones. The MFS is a distinct gamma-ray high, situated close to the strongly erosional upper sequence boundary. The thickness of the sequence attains a maximum of $69 \mathrm{~m}$ in West Lulu-1 (Fig. 6).

No stratigraphically useful bioevents were recorded from this sequence, but the lack of Toarcian bioevents (as discussed above with respect to the Pliens-1 and Pliens-2 sequences) and the LOD of Kekryphalospora distincta in the sequence above, may be seen as indirect evidence of an Aalenian or earliest Bajocian age.

\section{Baj-1 sequence}

The Baj-1 sequence extends throughout the Søgne Basin and the Tail End Graben (Nora-1), and further south to the northern and eastern parts of the Salt Dome Province (e.g. Alma-1, O-1). It may also be present in structurally deep locations elsewhere in the Salt Dome Province. The lower sequence boundary is a pronounced erosional surface (Figs 4, 6, 7). The lower part of the sequence typically consists of two laterally extensive channel sandstones separated by a fining-upwards/coarsening-upwards fine-grained interval (e.g. Amalie-1; Fig. 6). The channel sandstone interval may be interpreted as a lowstand systems tract (LST). Overlying this interval is a fining-upwards TST (Amalie-1, West Lulu-1; Fig. 7). The HST consists of floodplain sandstones and mudstones. The thickness of the sequence attains a maximum of $99 \mathrm{~m}$ in Amalie-1.

The LOD of Kekryphalospora distincta in the upper part of this sequence in the Alma-1 well indicates an Aalenian or earliest Bajocian age for the sequence (Fig. 3B).

\section{Bat-1 sequence}

This sequence is present in all wells that encountered Middle Jurassic deposits in the Søgne Basin, the Tail End Graben, the Salt Dome Province and the southernmost Heno Plateau (Figs 6, 7). In most wells, the lower sequence boundary is located at the base of a finingupwards channel sandstone (e.g. West Lulu-1; Fig. 6). The MFS is located in a mudstone interval, several metres thick. The HST is rarely present due to erosion; where present (e.g. West Lulu-1; Fig. 6), it consists of a coarsening-upwards interval of interbedded mudstones and sandstones. The thickness of the sequence attains a maximum of $64 \mathrm{~m}$ in West Lulu-1.

The occurrence (in a core sample) of Adnatosphaeridium caulleryi in the lower part of this sequence in West Lulu-1 indicates an age no older than Bathonian (Fig. 3B). In combination with the occurrence of Impletosphaeridium varispinosum immediately above the upper boundary of the sequence in West Lulu-3, this indicates a possible age range for this sequence of latest Bajocian - earliest Callovian.

\section{Cal-1 sequence}

This sequence is present in areas where the Bat-1 sequence is also found (Fig. 8A). In most wells, the lower sequence boundary is a very distinct erosional surface (see Amalie-1; Fig. 6), which locally shows truncation of at least 10-20 m (e.g. West Lulu-3; Fig. 7). The sequence boundary is overlain by a section of fluvial to estuarine channel sandstones up to $30 \mathrm{~m}$ thick (e.g. Amalie-1), which is interpreted as the fill of an incised valley. This interval probably represents the LST and the lowermost part of the TST. In the Søgne Basin and the Tail End Graben, the remainder of the TST consists of a succession of sandstone-dominated, paralic to shallow marine deposits, overlain by fully marine mudstones (Fig. 7). The paralic deposits include a number of coal beds, up to $3 \mathrm{~m}$ thick. The HST consists of a rather indistinct coarsening-upwards interval of marine mudstones. The sequence has a depocentre in the northern part of the Tail End Graben (Fig. 8A). In the Nora-1 well, where the sequence includes a section that contains tuffaceous sediments (4986-4932 m), it attains a thickness of $288 \mathrm{~m}$. In other wells, the sequence does not exceed $100 \mathrm{~m}$ in thickness.

The LOD of Impletospaeridium varispinosum in the lower part of this sequence in West Lulu-3 combined with the LOD of Ctenidodinium continuum in the sequence above (Ox-1) in U-1 and West Lulu-1 indicate an Early Callovian to earliest Oxfordian age for this sequence. The occurrence of Wanaea acollaris and W. thysanota in the middle part of the sequence in the John Flank-1 and West Lulu-1 wells supports this age assignment (Fig. 3A).

\section{Basin evolution}

Deposition resumed in the Danish Central Graben with the accumulation of uppermost Aalenian or lowermost Bajocian terrestrial sediments after the regional uplift and possible incipient collapse of the domal structure. Subsequent Middle Jurassic deposits rest unconformably on pre-Jurassic and Lower Jurassic sediments (Fig. 4). 
The initiation of syn-rift subsidence is demonstrated by an asymmetric distribution of the sediment package in the Søgne Basin as shown by seismic evidence (Møller 1986, fig. 5; Cartwright 1987; Korstgaard et al. 1993, figs 39, 40) and well log data (Andsbjerg 2003, this volume). Salt tectonics also influenced sediment distribution and the location of local depocentres in the Søgne Basin, the Tail End Graben and the Salt Dome Province (Mogensen et al. 1992; Korstgaard et al. 1993).

Middle Jurassic deposits are preserved in the Søgne Basin, the Tail End Graben and the Salt Dome Province with a depocentre located to the east near the Coffee Soil Fault (Figs 4, 7). Sandstones and mudstones of sequences Aalen-1 - Bat-1 were deposited in a fluvially dominated environment during the early part of the Middle Jurassic (latest Aalenian/earliest Bajocian - Late Bathonian; Fig. 9A). Deeper parts of the basins were periodically inundated by lakes. Lacustrine conditions in the central parts of the basins were coeval with wet floodplain conditions in marginal locations.

The occurrence locally of rare marine palynomorphs and tidal indicators such as flaser bedding and double mud-drapes suggest that deposition took place in a coastal plain setting. However, during this period, fully marine conditions are only reported from the Dutch part of the
Central Graben (van Adrichem Boogaert \& Kouwe 1993). A coastline must therefore have been located in the southern part of the Danish sector or in the German sector of the Central Graben. The regional transport direction in the Danish Central Graben was probably towards the coastline in the south, parallel to the basin axis.

Within the Middle Jurassic succession, several levels of well-developed, erosionally-based channels, prograding deltas and splays, and lacustrine and floodplain mudstone units form correlatable units over a wide area, comprising the Søgne Basin and the Tail End Graben. This suggests a common, external control on base level, such as rift tectonics, eustatic sea-level change, climate change or a combination of these factors.

In the Søgne Basin, the northern Tail End Graben and possibly in the Salt Dome Province, the deposits of the Aalen-1 - Bat-1 sequences are cut by a significant erosion surface, the basal sequence boundary of Cal-1 (Fig. 7). The development of this surface was caused by a major fall in relative sea level. At the time of formation of this surface, the regional slope had changed from a southwards to a northwards dip (Andsbjerg 2003, this volume). The erosional surface, which is commonly developed at the base of extensive fluvial or estuarine channel sandstones, is suggested to be the bounding
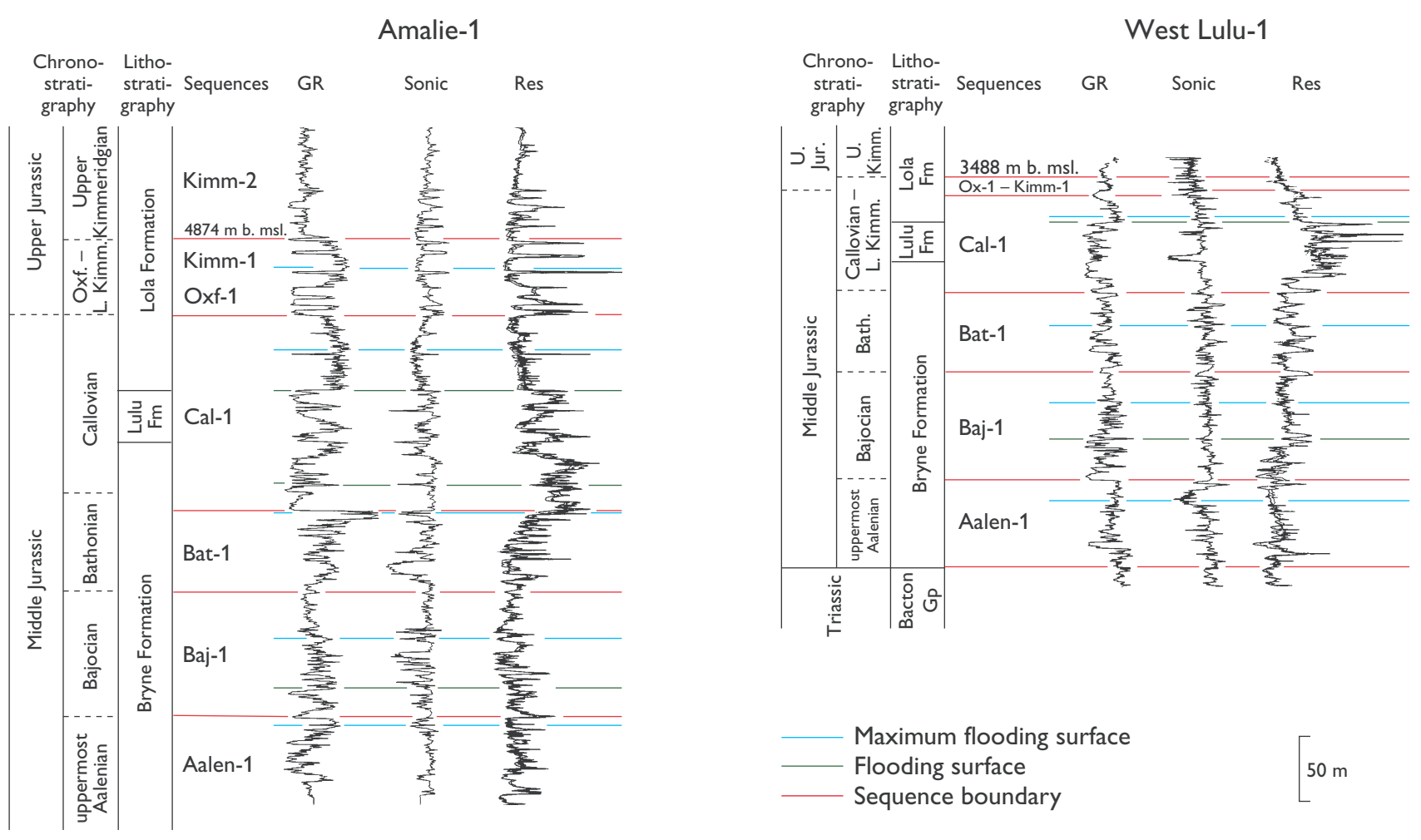

Fig. 6. Middle-Late Jurassic sequences in the Amalie-1 and West Lulu-1 wells illustrating, in particular, the characteristics of the Middle Jurassic (Aalen-1 - Cal-1) sequences. Bath., Bathonian; Jur., Jurassic; Kimm., Kimmeridgian; L., Lower; Oxf., Oxfordian; U., Upper. 


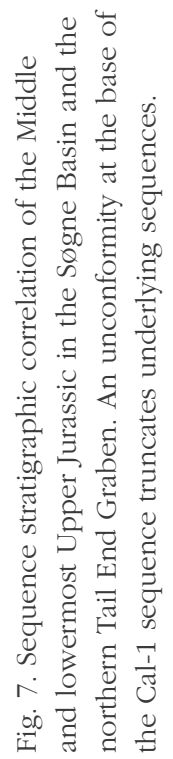
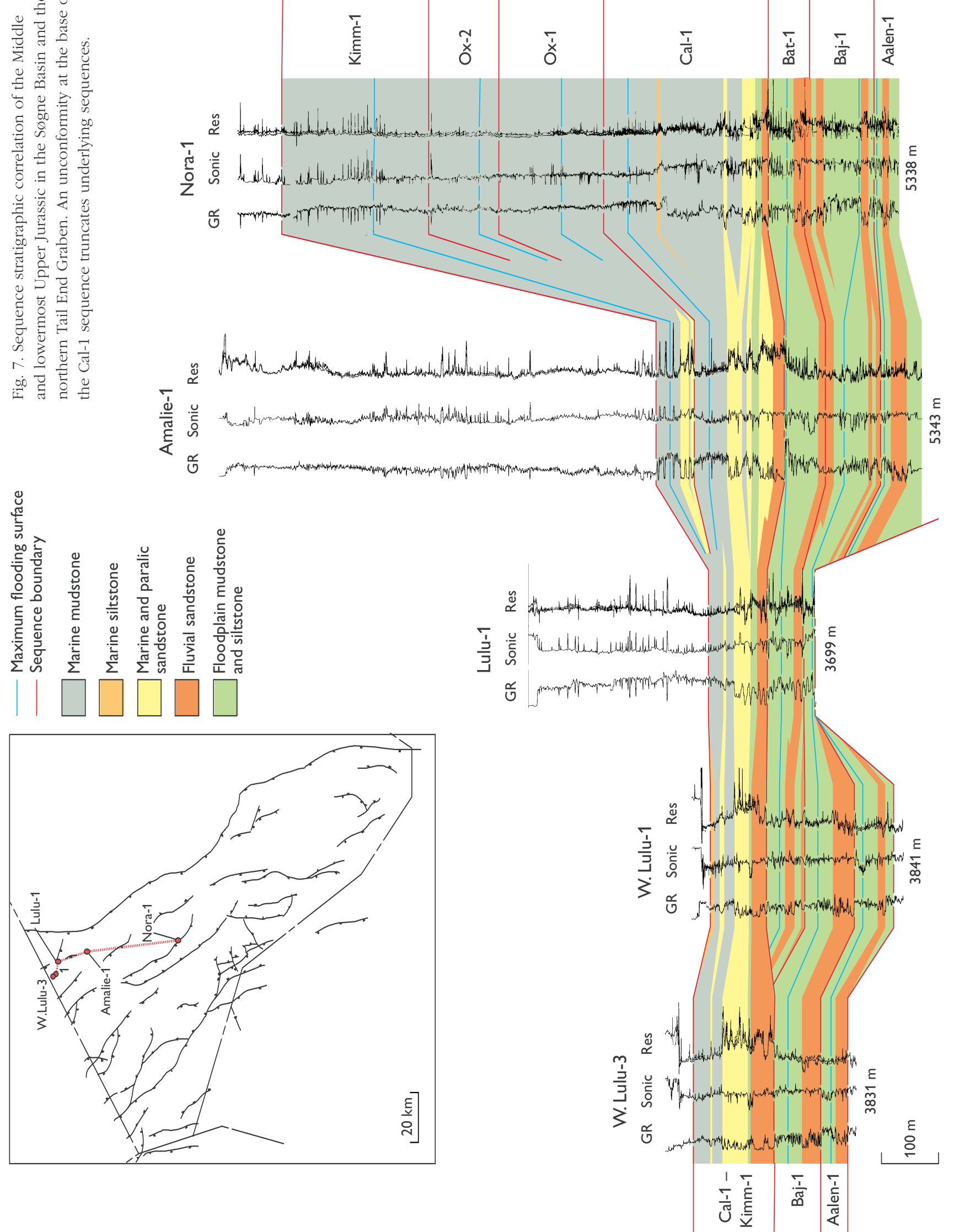

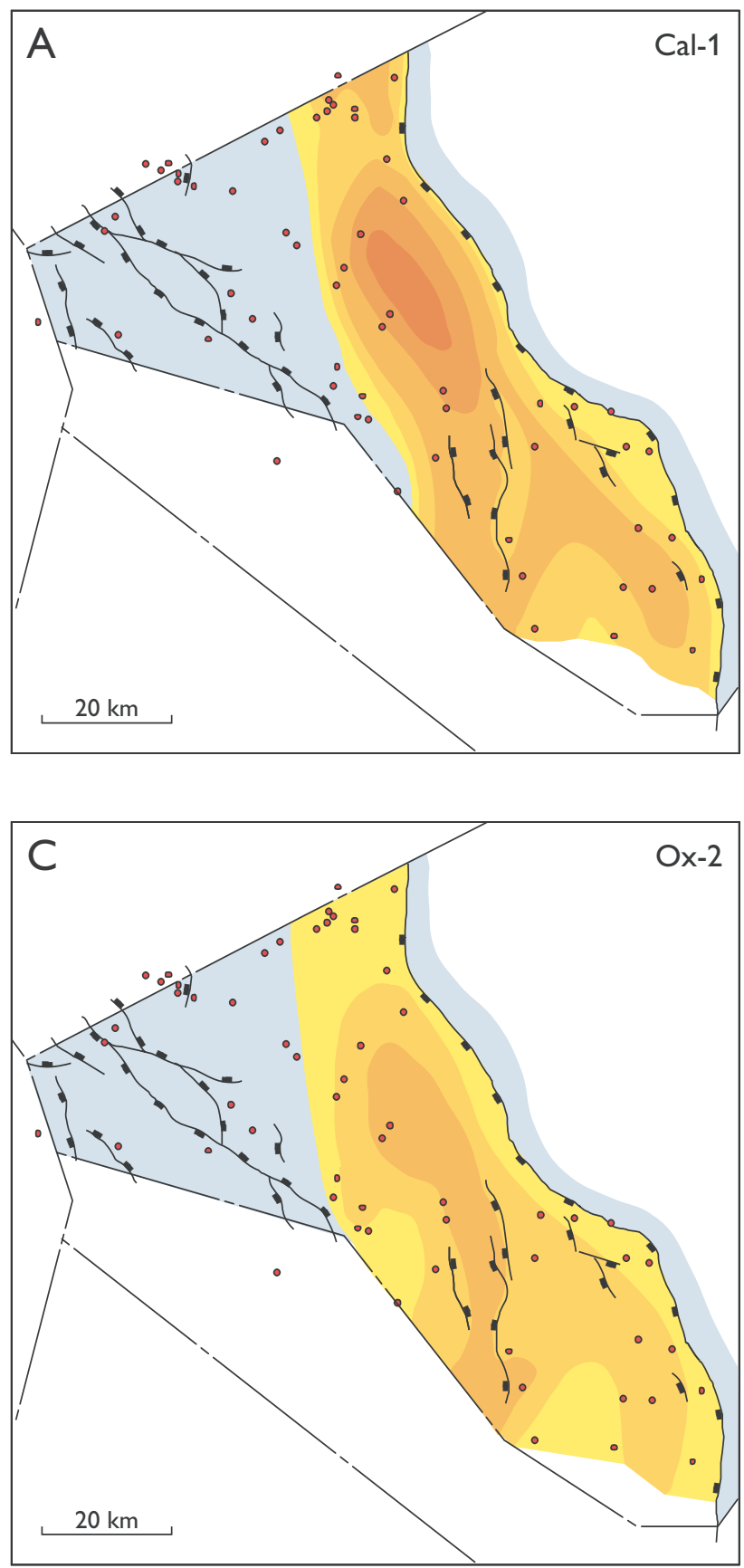

surface of an incised valley (Andsbjerg 2003, this volume). The valley-fill is dated to the latest Late Bathonian - Early Callovian. In the Søgne Basin, the channel sands were initially deposited in straight or sinuous rivers, which show an increase in tidal influence with time. In the Salt Dome Province, channel sandstones are either stacked or isolated and may show fining-upwards trends typical of sinuous channel fills or blocky gamma-ray motifs, indicating deposition in a straight or braided river (e.g. John Flank-1, U-1; Fig. 4; Koch 1983). The

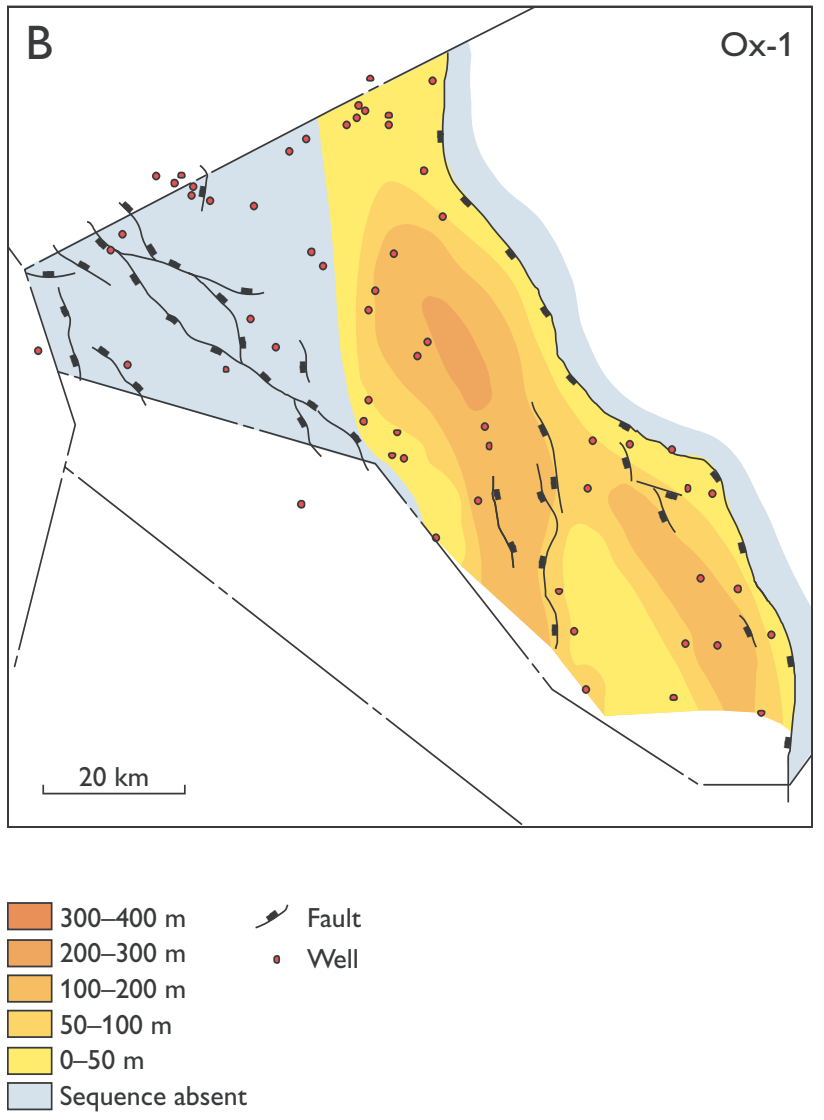

Fig. 8. Isochore maps of the Cal-1 (A), Ox-1 (B) and Ox-2 (C) sequences. The distribution of the Cal-1 and Ox-1 sequences illustrates a pronounced depocentre in the northern Tail End Graben, continuing south into the Rosa Basin. A second depocentre is present in the southern Tail End Graben eastern Salt Dome Province. The three maps chart a progressive transgression in the area of the Ravn and Elly wells (Fig. 1), in the south-eastern part of the Heno Plateau.

incised valley-fill of the Søgne Basin is capped by a coal bed up to 3 m thick.

Later in the Callovian, a low-energy coastal plain or delta plain characterised by small distributary channels, lagoons and coal swamps, was established in the southern part of the study area (Koch 1983). Contemporaneously, a barrier coast separated tidal lagoons at the margins of the Søgne Basin and the northern Tail End Graben from a wave-dominated marine bay in the central and eastern parts of these basins (Fig. 9B). 


\section{Phase 4. Rift pulse related transgression} (Early Oxfordian - Early Kimmeridgian)

\section{Sequence definitions}

\section{Ox-1 sequence}

This sequence is restricted to the Tail End Graben, the deeper parts of the Søgne Basin, the Salt Dome Province and the flanks of the Heno Plateau (Fig. 8B). The lower boundary of the sequence is located at the top of a well-developed coarsening-upwards interval (e.g. Deep Gorm-1; Nora-1; Fig. 10). At the western margin of the
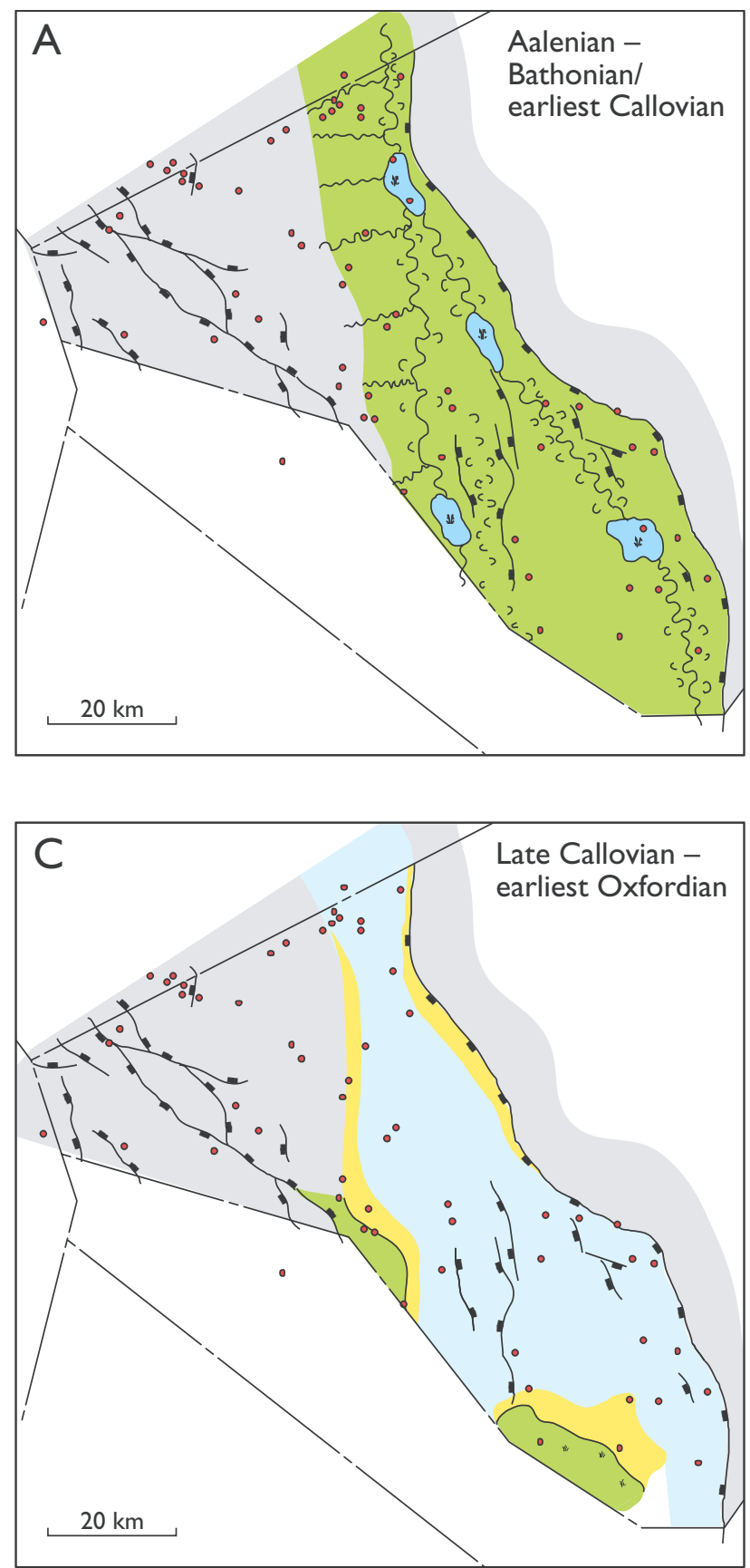

basin, a sandy LST up to $12 \mathrm{~m}$ thick may be present, erosionally overlying pre-Jurassic deposits (e.g. Elly-2; Fig. 10). In most wells, the sequence consists of marine mudstones; only in Elly-2 are sandstones a major component of the sequence. The thickness of the sequence attains a maximum of $189 \mathrm{~m}$ in Nora-1. A significant depocentre occurs in the northern part of the Tail End Graben (Fig. 8B).

The LOD of Ctenidodinium continuum in the middle part of the sequence in U-1 indicates an Early Oxfordian age for at least the lower part of the sequence. Combined with the LOD of Rigeaudella aemula close to the upper boundary in the Falk-1 well, this indicates an Early-Middle Oxfordian age for the sequence (Fig. 3C)

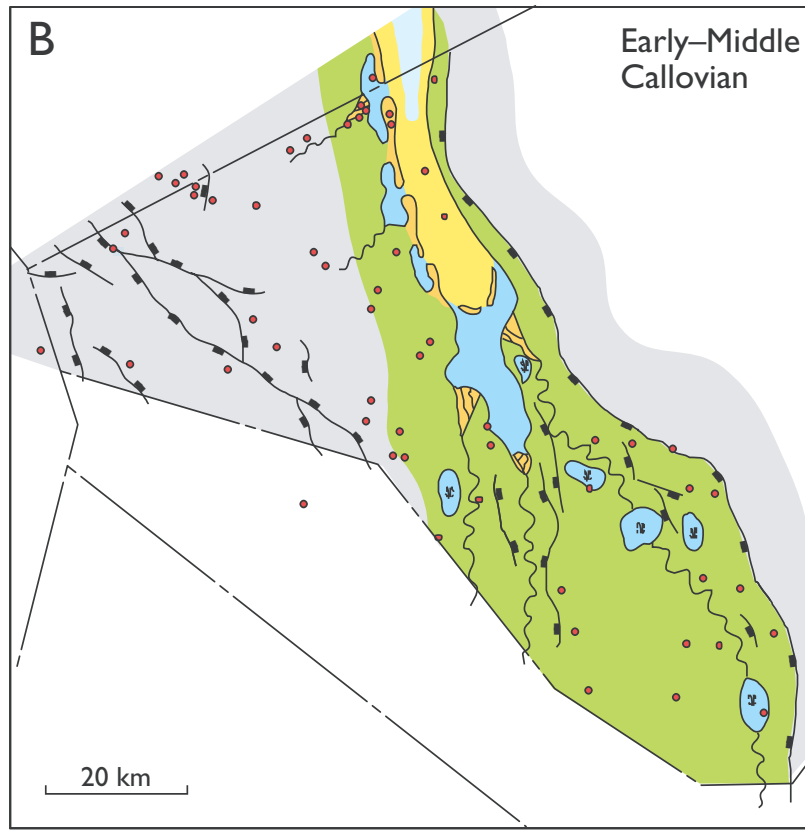

$\square$ Shelf
Shoreface/shore
Lagoon and barrier
Bayhead delta
Floodplain with river
Lake
No deposition/no preservation

Fig. 9. Palaeogeographic maps for the Middle - earliest Late Jurassic. The maps illustrate the gradual transition from a terrestrially-dominated environment (A) through a tidallyinfluenced coastal plain (B), to a fully marine environment $(\mathbf{C})$. Deposits of the lowermost part of the Middle Jurassic succession may have been present in the western part of the Danish Central Graben, and removed by erosion during hanging-wall uplift in association with early half-graben subsidence. Due to lack of data, the distribution of Middle Jurassic deposits in the Feda Graben is uncertain. 


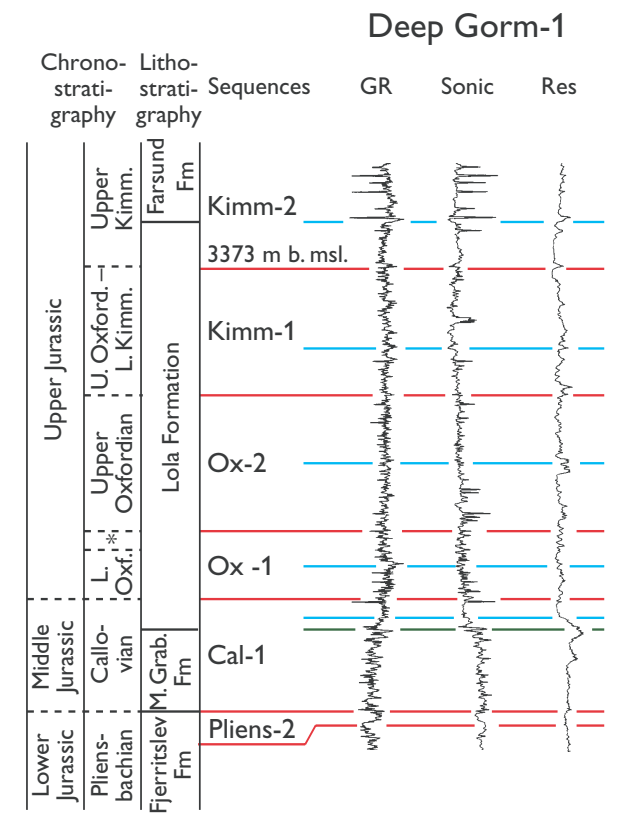

* Middle Oxfordian

Nora-1

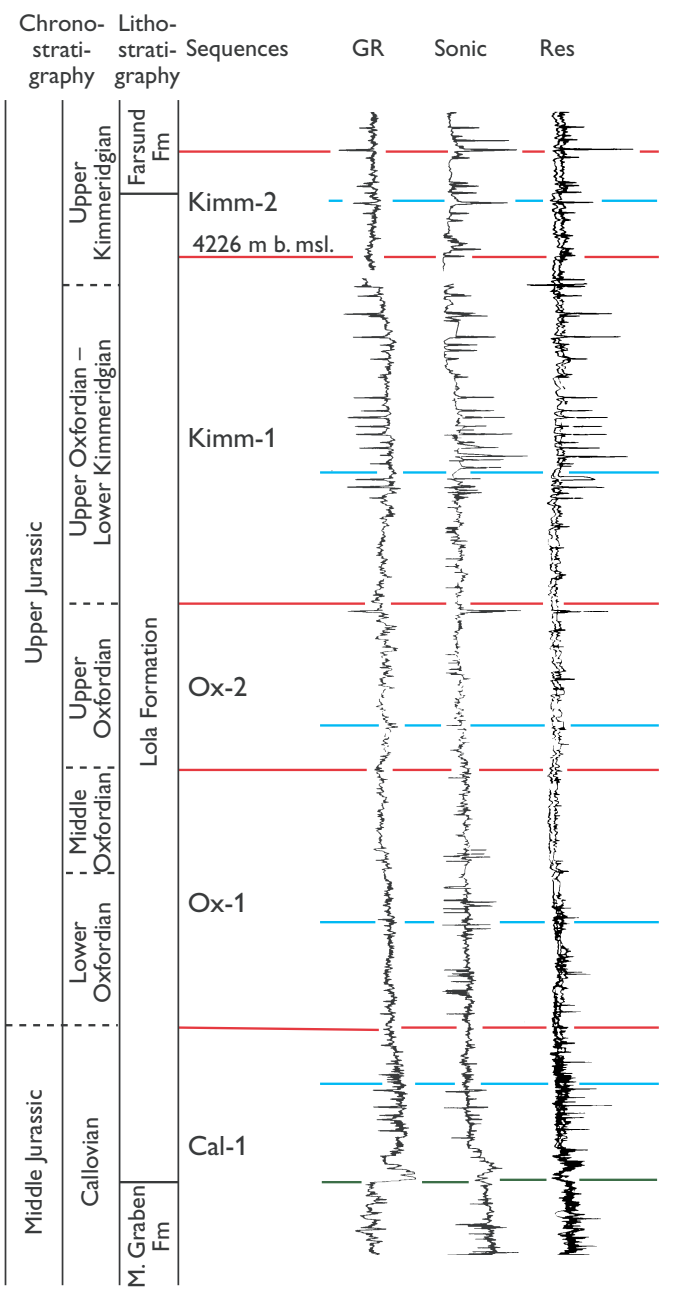

Elly-2

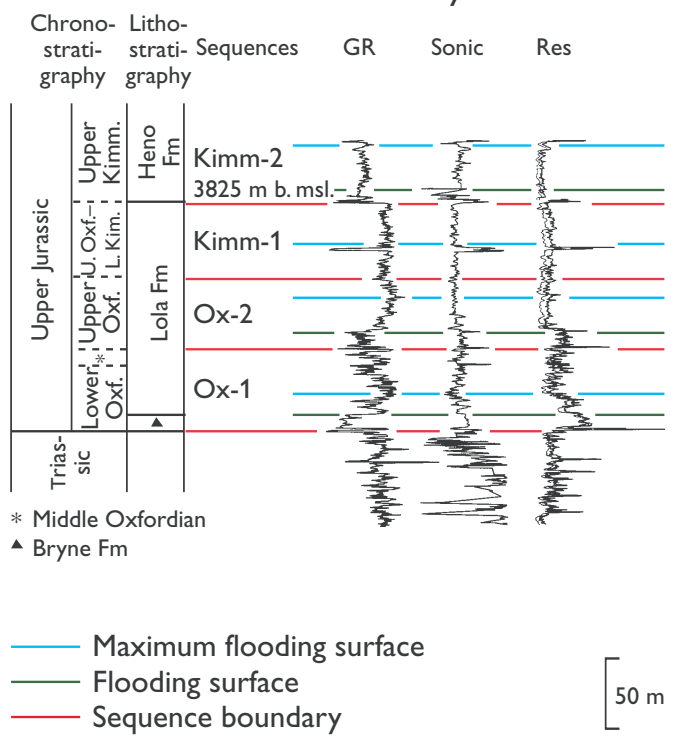

Fig. 10. Sequence stratigraphic breakdown of the lower Upper Jurassic in the Deep Gorm-1, Elly-1 and Nora-1 wells illustrating the features of the sequences Ox-1 - Kimm-1. Kim./Kimm., Kimmeridgian; L., Lower; M. Grab., Middle Graben; Oxf./Oxford., Oxfordian; U., Upper.

\section{Ox-2 sequence}

The distribution of this sequence corresponds to that of Ox-1 (Fig. $8 \mathrm{C}$ ). The lower sequence boundary is normally located at the top of a coarsening-upwards interval (e.g. Nora-1; Fig. 10). In a few wells situated at the western margin of the basin, the lower sequence boundary may be located at the sharp base of an up to $10 \mathrm{~m}$ thick sandstone unit referred to the LST (e.g. Elly-2). With the exception of these sandstones at the basin margin, the sequence consists of marine mudstones. The thickness of the sequence attains a maximum of $117 \mathrm{~m}$ in Nora-1. A depocentre for this sequence extends from the northern Tail End Graben to the Rosa Basin (Fig. 8C).

The LOD of Rigeaudella aemula immediately below the lower sequence boundary in Falk-1 combined with the LOD of Compositosphaeridium polonicum close to the upper boundary of this sequence in U-1 indicates an earliest Late Oxfordian age for this sequence (Fig. 3C).

\section{Kimm-1 sequence}

The sequence is missing from the north-western part of the study area (Fig. 11A). The lower boundary of the sequence is normally located at the top of a coarsening-upwards interval (e.g. Nora-1; Fig. 10). In the Heno Plateau area, the MFS is normally situated immediately above a marked gamma/sonic spike (e.g. Elly-2, Ravn-1; Figs 10, 12). 
The sequence consists of marine mudstone. The maximum measured thickness is $250 \mathrm{~m}$ (Nora-1). The sequence has a well-defined depocentre in the central part of the Tail End Graben (Fig. 11A).

The LOD of Compositumsphaeridium polonicum immediately below the lower boundary of this sequence in U-1 and the LOD of Scriniodinium crystallinum and of Nannoceratopsis pellucida close to the upper boundary in a number of wells (e.g. Amalie-1, Anne-3, Emma-1, John Flank-1, M-8, U-1, West Lulu-2) indicate a Late Oxfordian - Early Kimmeridgian age for this sequence (Fig. 3C).
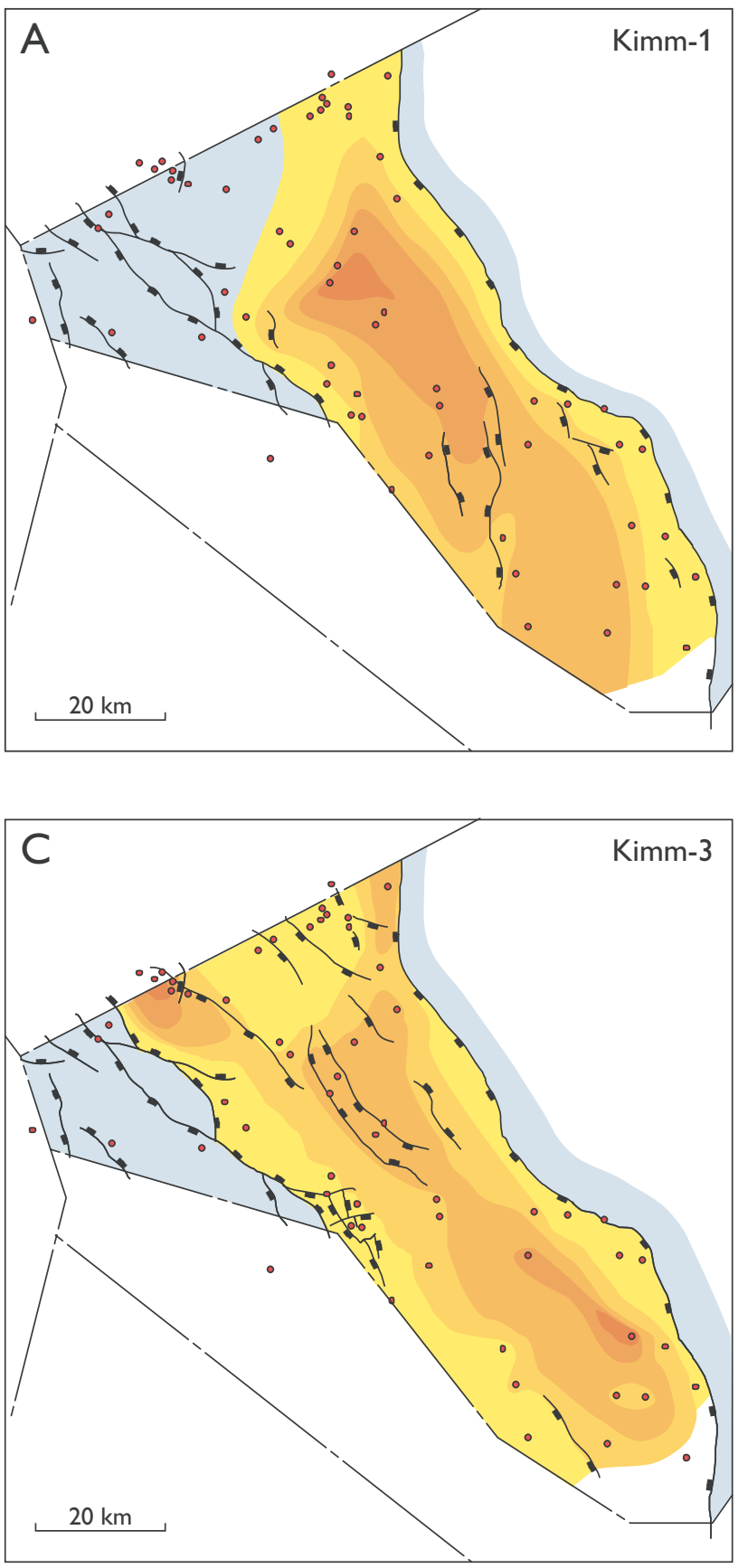

\section{Basin evolution}

In the Tail End Graben, subsidence along the Coffee Soil Fault accelerated in the Early Oxfordian resulting in a highly asymmetric distribution of the Oxfordian - Lower Kimmeridgian sediment package and in very large thicknesses of sediments in the central and eastern parts of the Tail End Graben (Figs 8A, 13; Fig. 13 faces page 294). This suggests that the Tail End Graben had entered the rift climax stage. During this phase, fault-controlled sub-

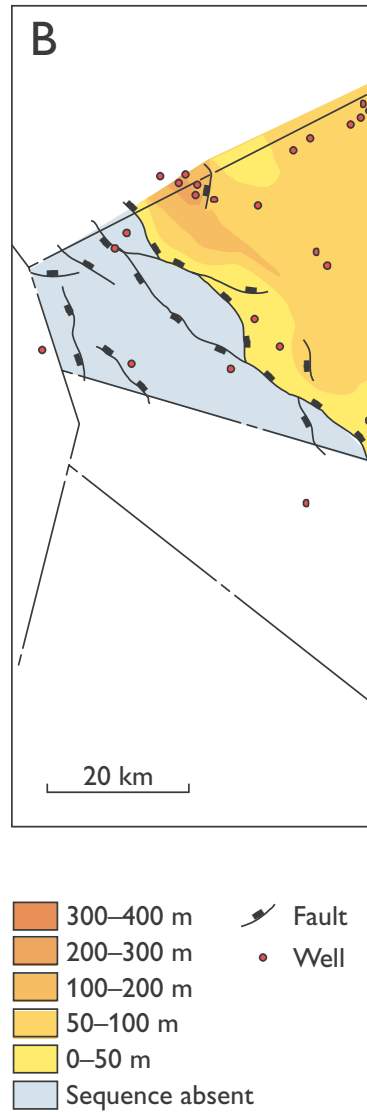

Fig. 11. Isochore maps of the Kimm-1 (A), Kimm-2 (B) and Kimm-3 (C) sequences. Comparison of A and B illustrates the progressive transgression of the northern Heno Plateau, the Gertrud Plateau and the Feda Graben area from the Late Oxfordian - earliest Late Kimmeridgian. Subsidence of the southern Feda Graben began during the latest Early - earliest Late Kimmeridgian. Note the relatively uniform distribution of sediments within the northern part of the Tail End Graben. During deposition of sequence Kimm-3 (Late Kimmeridgian), a central depocentre developed throughout the length of the Tail End Graben and the Salt Dome Province, striking roughly NW-SE. 

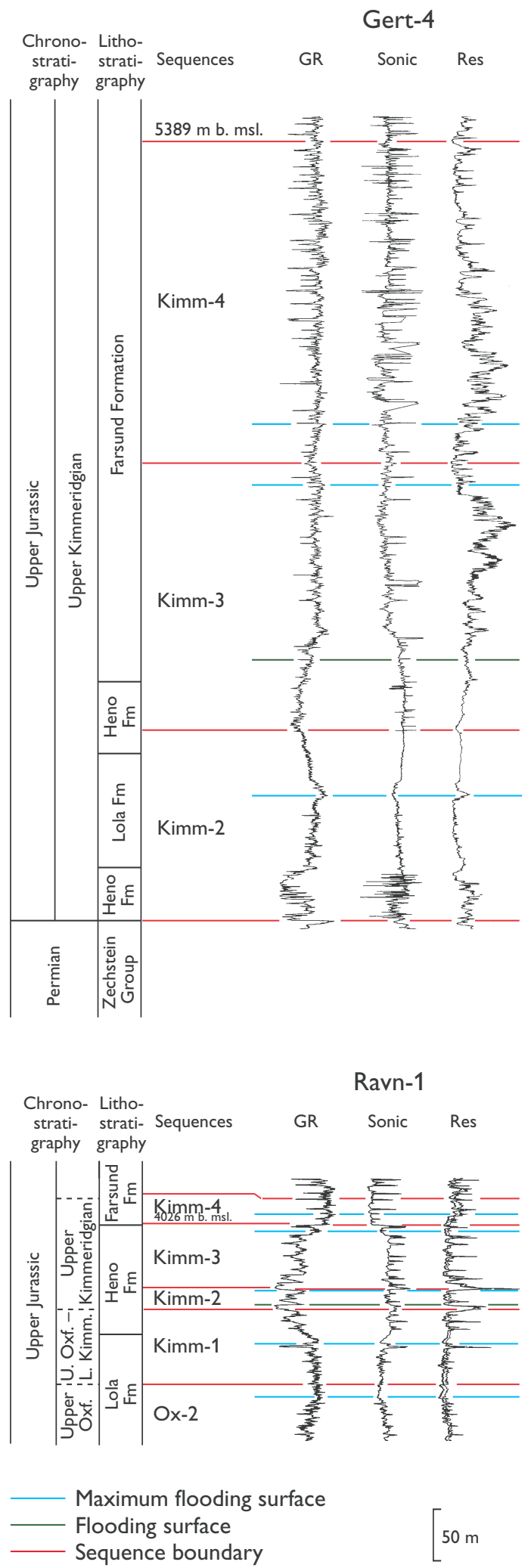

Fig. 12. Upper Jurassic stratigraphy of the Gert-4, Nora-1 and Ravn-1 wells illustrating, in particular, the characteristics of the Kimm-2 and Kimm-3 sequences. Kimm., Kimmeridgian; L., Lower; Oxf., Oxfordian; U., Upper.

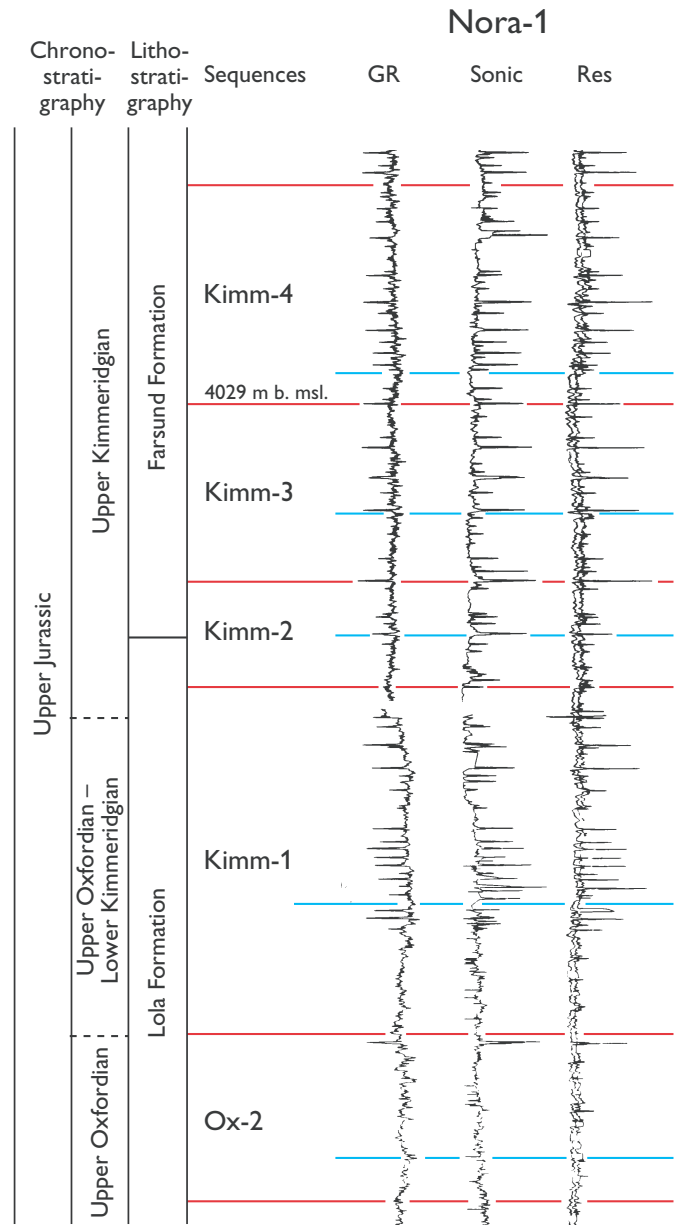

sidence in the Danish Central Graben mainly occurred along N-S-trending faults (Møller \& Rasmussen 2003, this volume).

The Lower Oxfordian - Lower Kimmeridgian succession is characterised by an overall transgressive development during which the depositional environment shifted from paralic to fully marine. The marked transgression reflects the interaction of the increased subsidence rate (see above) and a eustatic rise in sea level that has been documented from the North Sea rift system and elsewhere (Hallam 1978, 1988; Haq et al. 1988; Surlyk 1990).

Fully marine conditions were established in the Søgne Basin in latest Callovian - earliest Oxfordian times (Cal-1, TST) with the introduction of the shelf mudstones of the Lola Formation. A coastal plain environment probably still dominated parts of the Salt Dome Province to the south, indicating that the Callovian-Oxfordian transgression entered the Danish Central Graben from the north (Figs 9B, C).

During the Early Oxfordian, the Tail End Graben, the south-eastern marginal parts of the Heno Plateau, 
the Salt Dome Province, and the Rosa Basin were also transgressed (Ox-1, Ox-2; Figs 8B, C, 9C, 13). The remainder of the Heno Plateau and possibly areas further west were slowly submerged during the Late Oxfordian - Early Kimmeridgian (Kimm-1; Figs 11A, 14; Fig. 14 follows page 294). Marginal marine sandstones were deposited locally on the southern part of the Heno Plateau during this transgression (e.g. Elly-2; Fig. 14) but marine mudstones of the Lola Formation were deposited over most of the basin. A number of minor transgressive-regressive cycles can be discerned within the overall transgressive succession of marine mudstones (e.g. Nora-1; Fig. 13). The main basinal part of the study area was thus characterised by an offshore environment during this period. An inner shelf to shoreface environment developed, however, on the Gertrud Plateau and the northern part of the Heno Plateau at the end of this depositional phase (Fig. 15B).
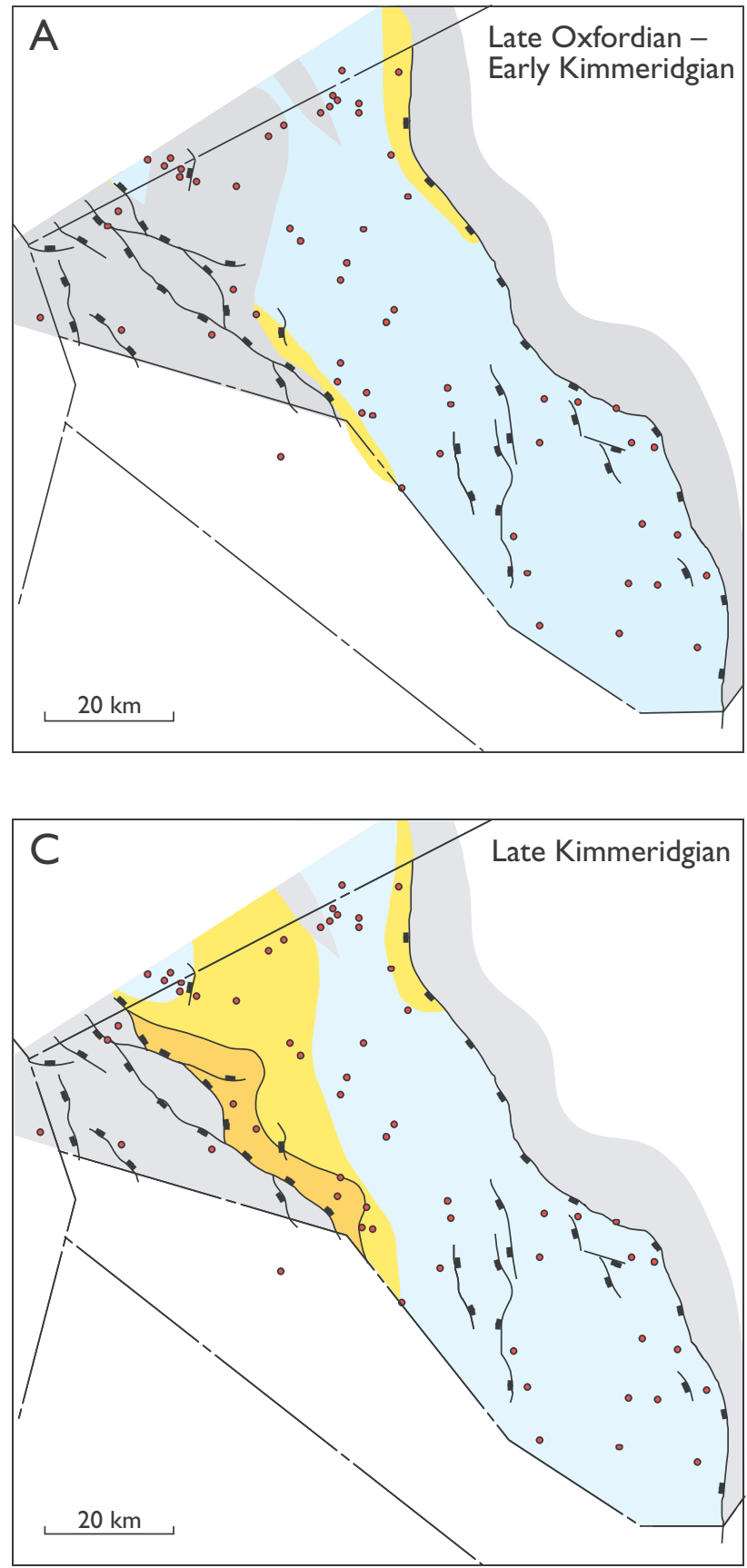
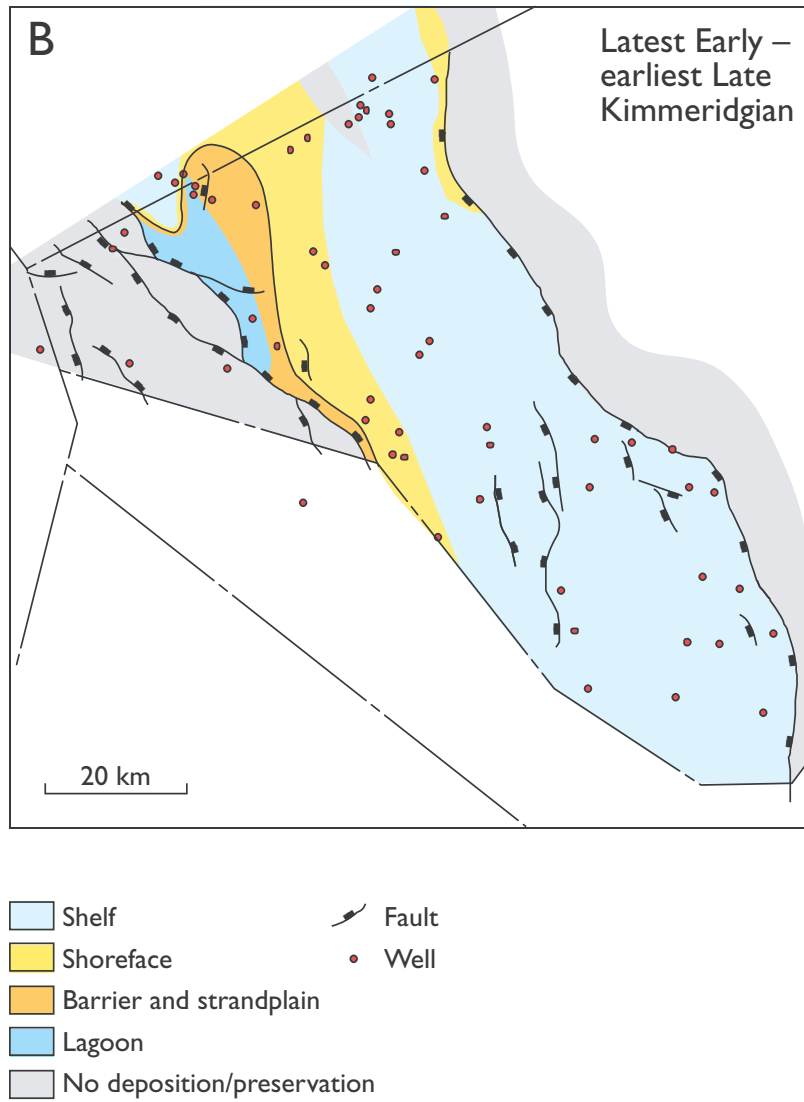

Fig. 15. Palaeogeographic maps for the Late Oxfordian - Late Kimmeridgian (Late Jurassic). During the Late Oxfordian Early Kimmeridgian (A), transgression continued across the northern Heno Plateau, the Gertrud Plateau and the Feda Graben areas (see also Fig. 9C). After a major regression (base Kimm-2 SB), marginal and shallow marine conditions dominated the plateau areas (B). Subsequently, renewed transgression resulted in a westwards shift of the coastline and extension to the west of paralic and marginal marine conditions $(\mathbf{C})$. 


\section{Phase 5. Shallow marine deposits and changing structural patterns (Late Kimmeridgian)}

\section{Sequence definitions}

\section{Kimm-2 sequence}

This sequence is found throughout the study area east of the Mads and Inge Highs (Fig. 11B). The lower boundary has been placed at a conspicuous surface that, even in the deeper parts of the basin, shows an abrupt shift from high to low gamma-ray values, probably indicating an erosion surface (Figs 10, 12). In parts of the study area, such as the Feda Graben, the northern part of the Gertrud Plateau and the northern part of the Heno Plateau, this surface coincides with the unconformity that separates the preJurassic and the Upper Jurassic deposits (e.g. Gert-4; Fig. 12).

On the Heno Plateau, the LST is thought to be represented by a unit of conglomerates and coarse-grained sandstones less than $5 \mathrm{~m}$ thick (e.g. Ravn-1; Fig. 12) although it should be noted that Johannessen (2003, this volume) refers this interval to the lowermost TST. In more distal settings, the LST is represented by a 10-15 m thick sandstone or sandy siltstone unit (e.g. Elly-2; Fig. 10). In the proximal settings of the Heno and Gertrud Plateaus and the southern Feda Graben, the TST consists of paralic and shallow marine sandstones and mudstones. In basinal settings (e.g. Nora-1), the TST is represented by a well-defined fining-upwards interval (Fig. 12). This interval consists of silty claystone, siltstone or silty sandstone, becoming coarser grained towards the Heno Plateau. In the central part of the Heno Plateau (e.g. Ravn-1), most of the HST was removed by erosion during the subsequent lowstand. On the northern Heno Plateau, the Gertrud Plateau and in the southern Feda Graben, the HST consists of a section that coarsens upwards from sandy siltstones to gravelly sandstones of shoreface origin (Johannessen et al. 1996; Johannessen 2003, this volume). In basinal settings, the HST consists of a coarsening-upwards interval of marine mudstones, siltstones and sandstones. The thickness of the sequence attains a maximum of $319 \mathrm{~m}$ in Cleo-1. Major depocentres for this sequence are located in the southern Tail End Graben - eastern Salt Dome Province, in the northern Tail End Graben - Søgne Basin and in the Feda Graben (Fig. 11B).

A latest Early Kimmeridgian to earliest Late Kimmeridgian age is indicated by the LOD of Endoscrinium galeritum in the lower part of the sequence in Edna-1 and West Lulu-1 and the FAD of Subtilisphaera? paeminosa and S.? inaffecta in the lower part of the sequence in Gert-1 combined with the LOD in the sequence above of Stephanelytron scarburghense in the Gert-2, Jeppe- 1 and Lulu-1 wells (Fig. 3C).

\section{Kimm-3 sequence}

The distribution of this sequence corresponds to that of the Kimm-2 sequence (Fig. 11C). In the central part of the Heno
Plateau (e.g. Ravn-1; Fig. 12), the lower sequence boundary is represented by an erosion surface overlain by shallow marine conglomerates or gravelly sandstones. Further north, on the Heno Plateau and in the Gertrud Plateau - Feda Graben area, the sequence boundary is marked by a thin conglomerate in several wells (Johannessen 2003, this volume). In more basinal areas, south and east of the Heno Plateau, the lower sequence boundary is located at the top of a well-defined coarsening-upwards interval (e.g. Nora-1; Fig. 12). In the Heno Plateau - northernmost Salt Dome Province area (e.g. Ravn-1), the TST is developed as a backstepping set of parasequences that consist of marine silty sandstones, siltstones and claystones. In the Feda Graben - Gertrud Plateau area, the TST consists of shallow marine sandstones and siltstones that grade upwards to marine mudstones (e.g. Gert- 4 ; Fig. 12). In some wells (e.g. Jeppe-1; Fig. 14), an abrupt change from marine sandstones to mudstones, interpreted as a flooding surface, replaces part of the coarsening-upwards section. In the Tail End Graben (e.g. Nora-1), the TST is represented by a thin fining-upwards interval of marine mudstones. The HST typically consists of marine mudstones. In the Feda Graben - Gertrud Plateau area and in the Søgne Basin, the HST terminates in a distinct coarsening-upwards interval, which includes silt- and sandstones (e.g. Gert-4; Fig. 12). The thickness of the sequence attains a maximum of $387 \mathrm{~m}$ in Cleo-1. Major depocentres are located in the Søgne Basin, the Feda Graben and the southern Tail End Graben - Salt Dome Province (Fig. 11C).

The LOD of Stephanelytron scarburghense in the lower to middle part of this sequence in Gert-2 and Jeppe- 1 and the LOD of Endoscrinium luridum in the succeeding sequence (Kimm-4) indicate a Late Kimmeridgian age for this sequence (Fig. 3C)

\section{Basin evolution}

The basin configuration changed significantly during the late Early Kimmeridgian - Late Kimmeridgian. Fault activity and fault-related subsidence waned and at the end of the period a new pattern of dominantly NNWSSE-trending faults was established (Møller \& Rasmussen 2003, this volume). This development marked a pause between two rift pulses. At this time, the Tail End Graben, including the Søgne Basin and most of the Heno Plateau, formed one major half-graben with an eastwards-dipping hanging-wall slope. Accommodation space had been created in the Feda Graben prior to this phase. The Feda Graben was separated from the Tail End Graben by a transfer zone (Fig. 11B).

The lack of rift-related subsidence, probably combined with a regional fall in sea level in the beginning of this phase, caused a significant relative sea-level fall. This sea-level fall caused the development of a distinctive 
erosional sequence boundary traceable over most of the Danish Central Graben (Figs 13,14); it can be seen on seismic sections as an onlap surface (Erik S. Rasmussen, personal communication 1997).

The succeeding transgression, caused by eustatic or regional relative sea-level rise, gave rise to a gradual flooding of the Heno Plateau, the southern part of the Feda Graben and the Gertrud Plateau area. Two higherorder sea-level cycles can be recognised during this overall transgression; the Kimm-2 sequence records the first cycle, the Kimm-3 sequence the second.

While marginal areas were characterised by deposition of sand in shallow marine to paralic environments, low-energy marine conditions prevailed in the deeper parts of the basin during the Kimm-2 cycle (Fig. 15B). Sand was deposited in a high-energy shoreface environment on the southern part of the Heno Plateau and in a back-barrier environment on the northern part of the Heno Plateau and in the area of the Gert Ridge (Johannessen et al. 1996; Johannessen 2003, this volume). The flooding of the Heno Plateau area forced the coastline back from its position near the eastern margin of the plateau at the beginning of the transgression to the western margin of the Heno Plateau or possibly further west at the time of maximum flooding. Subsequently, the shallow areas in the western part of the basin were separated from the marine basin to the east by a zone of sand-dominated prograding shoreface. The coastline was re-established in a position at the eastern edge of the Heno Plateau at the end of this cycle (Fig. 15C).

In latest Early Kimmeridgian time (lower Kimm-2 sequence), the relatively limited accommodation space in the central parts of the Heno Plateau was rapidly filled with deposits of the LST and TST, before maximum flooding was attained (e.g. Ravn-1, Falk-1; Fig. 14). A relatively thick TST was deposited in the Feda Graben due to a rapidly subsiding basin floor. After the time of maximum flooding, most remaining available accommodation space occurred in the Tail End Graben and the deeper parts of the Feda Graben where a thick HST was deposited (e.g. G-1, Gert-4; Fig. 14). By the end of the first sealevel cycle (Kimm-2), an area consisting of the southern Feda Graben and the Heno and Gertrud Plateaus was exposed or dominated by shallow-water conditions. Deep-water conditions only prevailed in the central parts of the Tail End Graben and the Søgne Basin.

The Kimm-3 sequence is characterised by a major depocentre in the Feda Graben where thick marine deposits are related to the early onset of the next phase of subsidence. A central depocentre developed through- out the length of the Tail End Graben and the Salt Dome Province, striking roughly NW-SE (Fig. 11C).

Coarse-grained conglomeratic shoreface deposits were deposited immediately above the sequence boundary (the base Kimm-3 SB) on the Heno Plateau (Johannessen 2003, this volume). These deposits were overlain by backstepping parasequences of shallow marine sand and silt (e.g. Falk-1, Ravn-1; Figs 12, 13).

The beginning of the next phase of subsidence caused a gradual change from coarse- to fine-grained shallow marine deposits in basinal settings of the Feda Graben. An abrupt shift from shallow marine sandstone to offshore mudstone can be seen in marginal areas of the Feda Graben and on the Gertrud Plateau (e.g. Gert-2, Gwen-2, Jeppe-1; Fig. 14). When fully marine conditions were established in the Feda Graben, a very high rate of subsidence in this area impeded the re-establishment of paralic conditions during the highstand part of the cycle. In the Tail End Graben and Søgne Basin, the Kimm-3 sequence consists of a thin unit of marine mudstones.

At the beginning of Kimm-3 time, accommodation space on the Heno and Gertrud Plateaus was limited by an initial sea-level fall and a low rate of subsidence. The limited accommodation space available was mainly filled by deposits of the TST (Fig. 14). In the remainder of the study area, there was sufficient accommodation space for the development of the HST (e.g. Cleo-1, G-1; Figs 16, 17, following page 294). On the southern part of the Gertrud Plateau and adjoining parts of the Heno Plateau, the remaining accommodation space was filled with shallow marine HST deposits followed by exposure and bypass (e.g. Gwen-2; Fig. 14).

\section{Phase 6. Deep-water mudstones in a composite graben: rift pulses and passive subsidence (latest Late Kimmeridgian - middle Middle Volgian)}

\section{Sequence definitions}

\section{Kimm-4 sequence}

This sequence has the same areal distribution as the Kimm-2 and Kimm-3 sequences (Fig. 18A). On the Heno Plateau, the lower sequence boundary is typically placed where the lithology changes abruptly from the sandstones and siltstones of the underlying sequences to fully marine mudstones (e.g. Ravn-1; Fig. 12). In basinal areas, the lower sequence boundary is located at the top of a coarseningupwards interval, which in the Feda Graben (e.g. Gert-4) and in the Søgne Basin (e.g. Lulu-1; Fig. 17) may be distinct. In the Feda Graben 
- Gertrud Plateau area, the TST is well-developed (e.g. Gert-2, Gwen-2; Fig. 19), whereas over much of the Heno Plateau, the Salt Dome Province and in the Tail End Graben, it often occurs in a condensed form (e.g. Nora-1; Fig. 12). In general, the HST is much thicker than the TST (e.g. Gert-2, Nora-1; Figs 12, 19); both the TST and HST consist of marine mudstones. The thickness of the sequence attains a maximum of $318 \mathrm{~m}$ in Gert-4. The sequence has an elongated depocentre in the eastern part of the Tail End Graben and a secondary depocentre in the Feda Graben (Fig. 18A).

A Late Kimmeridgian age is indicated for the sequence based on the LOD of Stephanelytron scarburghense in the sequence below com-
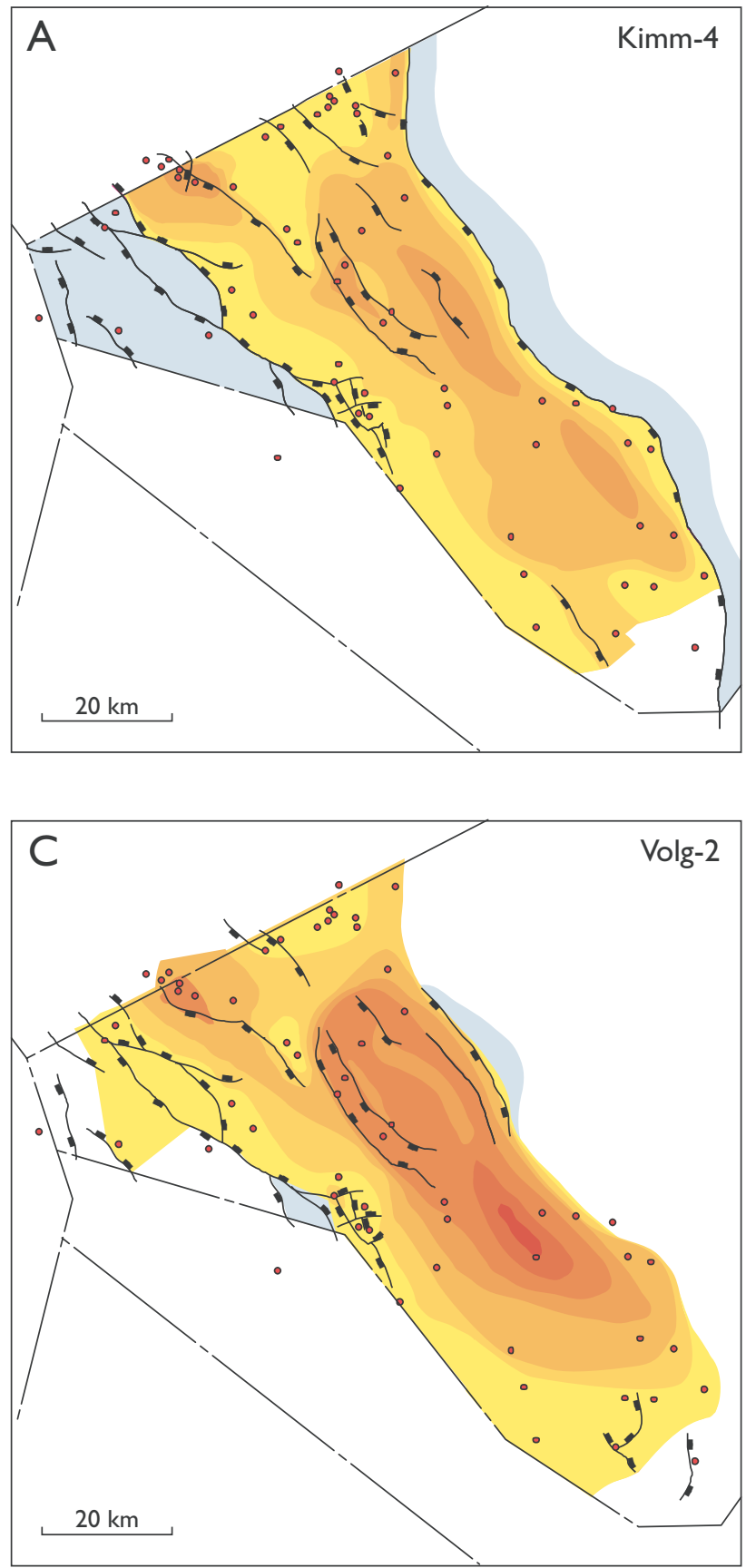

bined with the LOD of Endoscrinium luridum close to the upper sequence boundary in Amalie-1 and Cleo-1 (Fig. 3C).

\section{Volg-1 sequence}

This sequence has the same areal distribution as the previous sequences (Fig. 18B). In the Feda Graben - Gertrud Plateau area and on the Heno Plateau, the lower sequence boundary is located at the top of a thin but conspicuous coarsening-upwards interval (Fig. 19). In the more basinal settings of the Tail End Graben, the Søgne Basin, and the Salt Dome Province, the boundary is situated at the turnaround point between rather indistinct coarsening-upwards and fining-

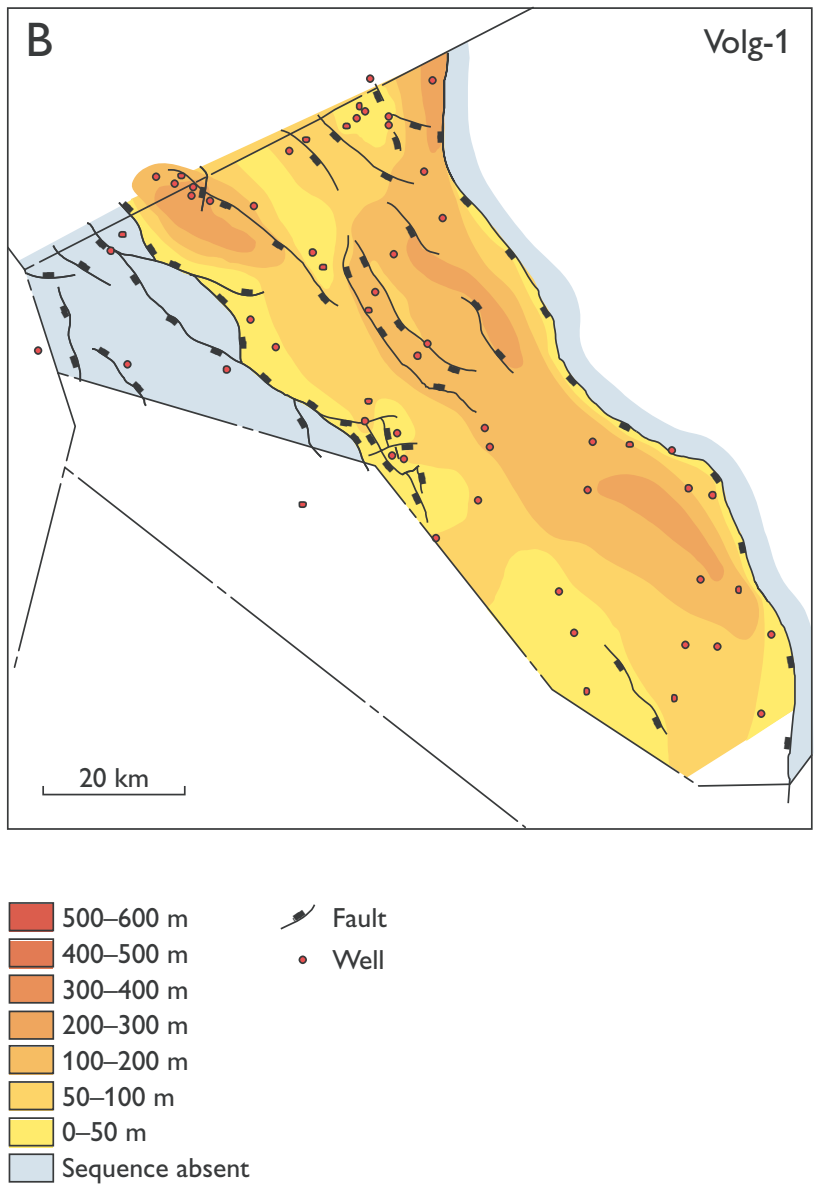

Fig. 18. Isochore maps of the Kimm-4 (A), Volg-1 (B), and Volg-2 (C) sequences. During the latest Kimmeridgian and earliest Volgian (A, B), an asymmetric basin geometry was reestablished with an elongate depocentre near the Coffee Soil Fault; a secondary depocentre developed in the eastern Søgne Basin during the earliest Early Volgian. The Outer Rough and Ål Basins were transgressed in the Early Volgian (C). 
Elin-1

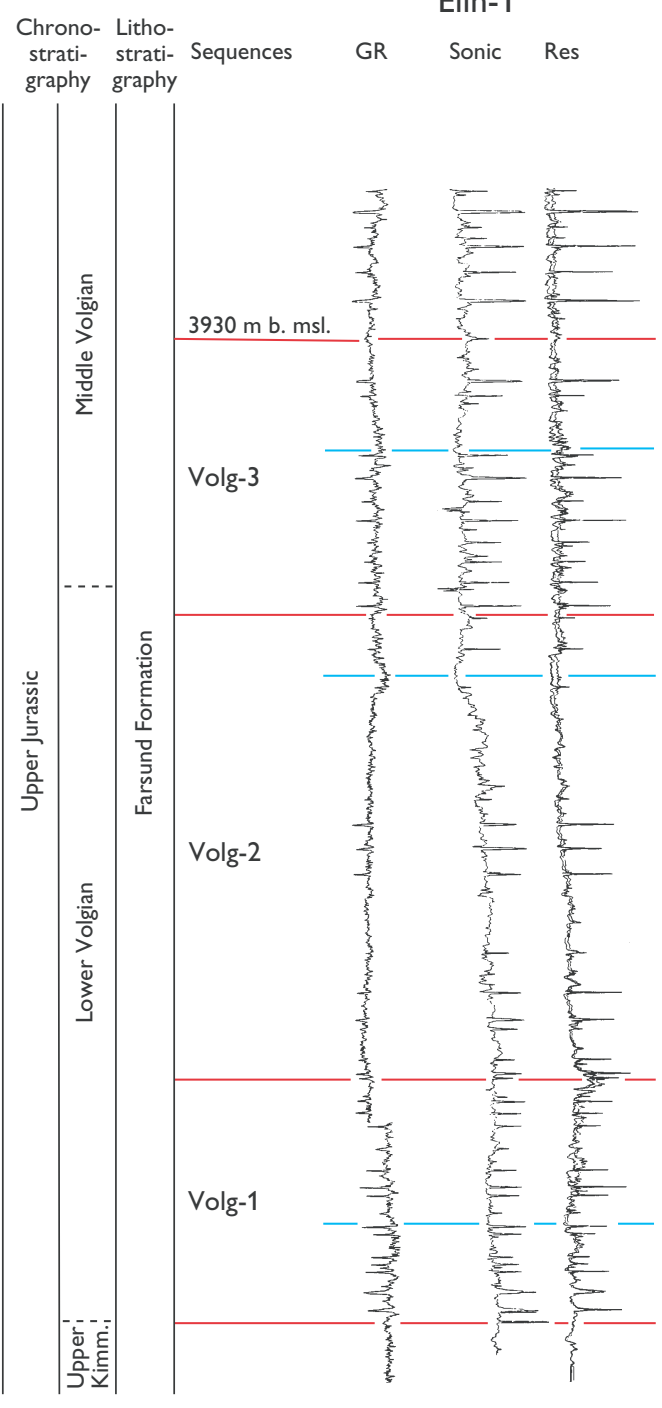

upwards units (e.g. G-1, Nora-1; Fig. 16). In several wells in the Salt Dome Province, the TST is missing and the MFS amalgamates with the underlying sequence boundary (e.g. Deep Gorm-1; Fig. 14). The MFS is marked by a conspicuous peak on the gamma-ray, sonic and resistivity logs. Both the TST and HST consist of marine mudstones. The thickness of the sequence attains a maximum of $210 \mathrm{~m}$ in Gert- 4 . The main depocentre of the sequence is in the eastern part of the Tail End Graben and in the eastern Søgne Basin. A secondary depocentre is present in the Feda Graben (Fig. 18B).

The sequence is referred to the earliest Early Volgian (Fig. 3C) based on the LOD of Endoscrinium luridum in the sequence below combined with the LOD of Subtilisphaera? paeminosa in the upper part of the sequence in a number of wells (e.g. Amalie-1, Deep Gorm-1, Gert-2, -4, Gwen-2, Ravn-2, U-1).

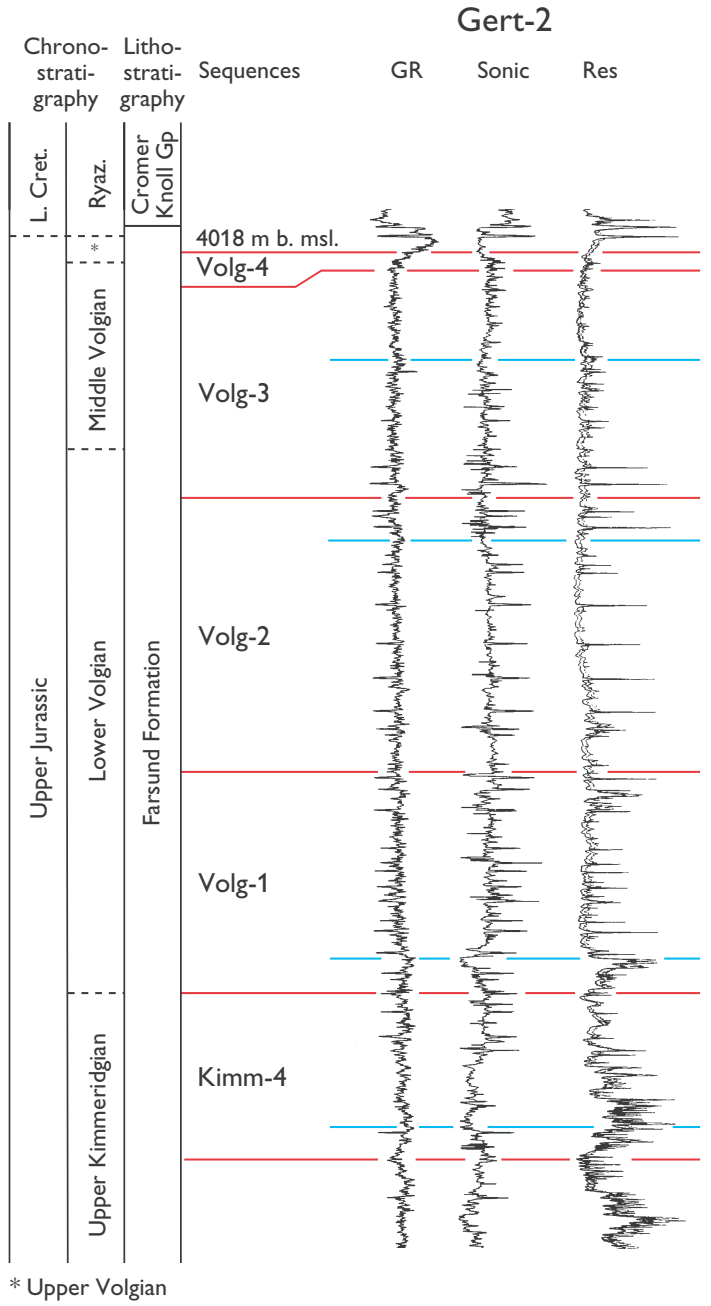

Gwen-2

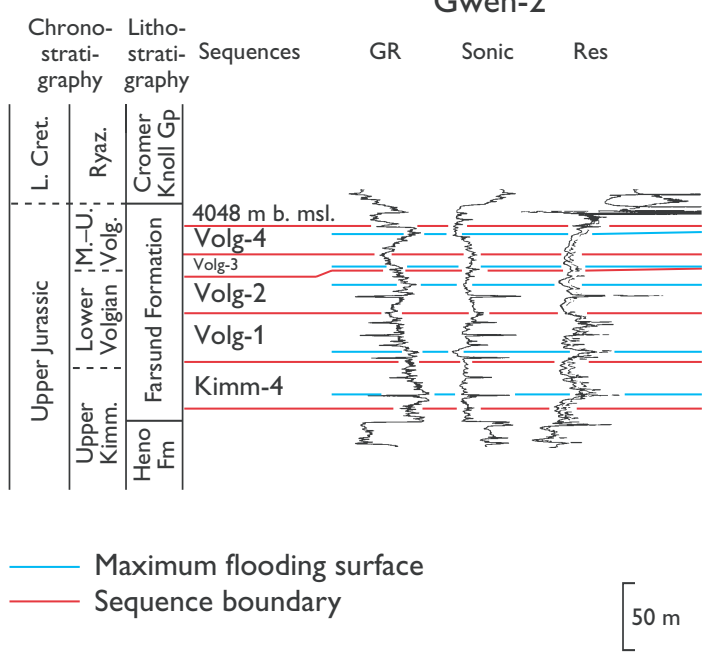

Fig. 19. Upper Kimmeridgian - Volgian sequence stratigraphy of the Elin-1, Gert-2 and Gwen-2 wells, highlighting the features of the Kimm- 4 - Volg-3 sequences. Kimm., Kimmeridgian; L. Cret., Lower Cretaceous; M.-U. Volg., Middle-Upper Volgian; Ryaz., Ryazanian. 

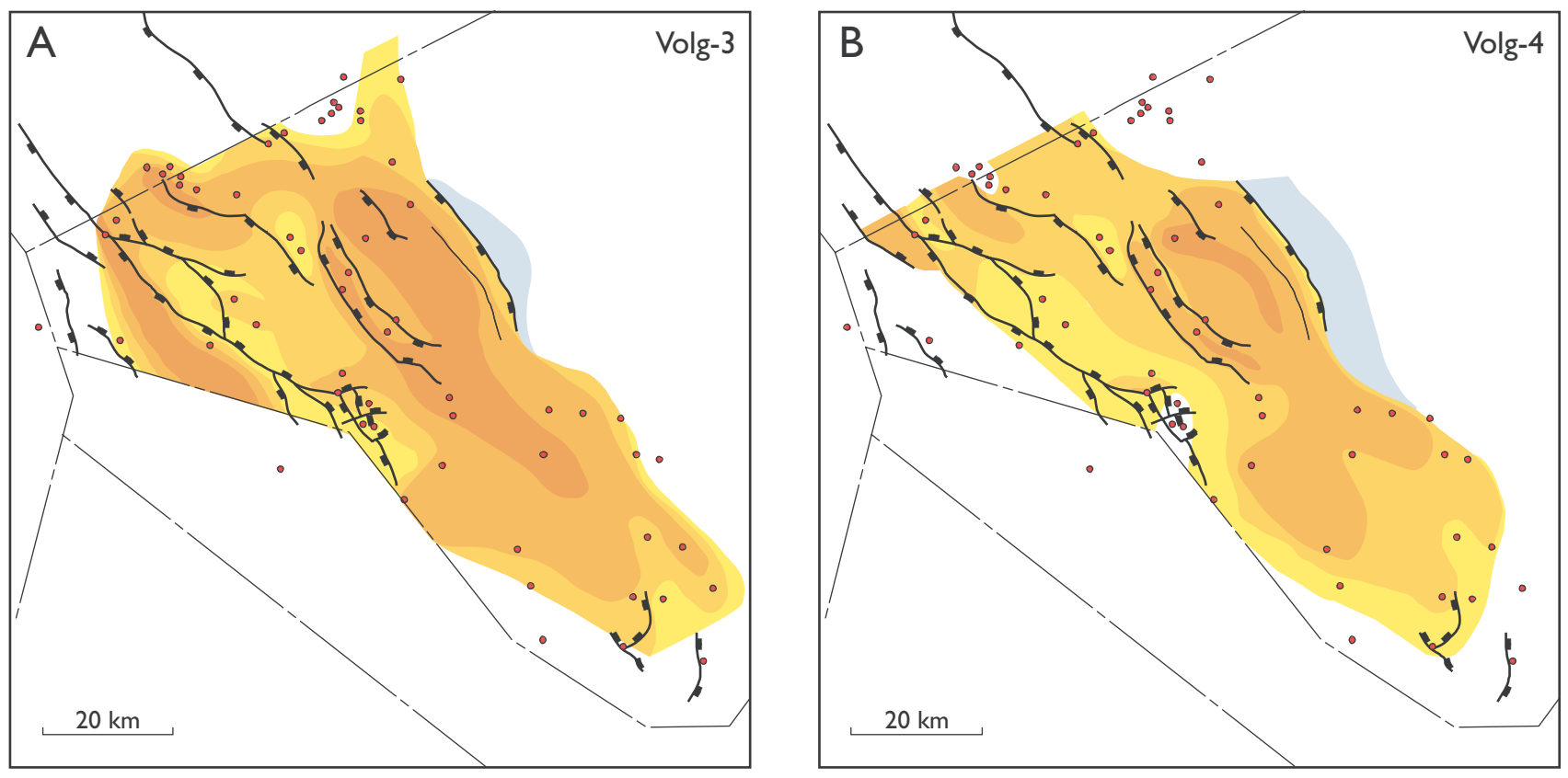

\section{$200-300 \mathrm{~m}$}

$100-200 \mathrm{~m}$

$50-100 \mathrm{~m}$

0-50 m

Sequence absent
Fig. 20. Isochore maps of the Volg-3 (A) and Volg-4 (B) sequences. In the latest Early - middle Middle Volgian (A), subordinate depocentres developed in the Arne-Elin Graben and in the Outer Rough Basin. The asymmetric half-graben geometry of the Tail End Graben became less pronounced during the Middle-Late Volgian (B).

\section{Volg-2 sequence}

Although partly or completely eroded in most wells in the Salt Dome Province, this sequence is recognised throughout the remainder of the Danish Central Graben, including the Outer Rough and Ål Basins (Fig. 18C). The lower sequence boundary of this sequence is rather indistinct in most wells, being located at the top of a weak coarsening-upwards trend within the HST of the Volg-1 sequence below (Fig. 19). In basinal settings, where the sequence is relatively thick, the TST is four to five times thicker than the HST; in settings where the sequence is relatively thin, the TST and HST are of comparable thickness. The sequence consists of marine mudstones. The maximum thickness of the sequence measured in wells is $344 \mathrm{~m}$ (E-1) although seismic data indicate thicknesses in excess of $400 \mathrm{~m}$ in the prominent Tail End Graben depocentre. A secondary depocentre is present in the Feda Graben (Fig. 18C).

The LOD of Subtilisphaera? paeminosa in the sequence below (Volg-1) and of Oligospaeridium patulum in the sequence above (Volg-3) indicate an Early Volgian age for this sequence. This is further supported by the LOD of Cribroperidinium? longicorne in the lower part of the sequence in the Eg-1 and Emma-1 wells (Fig. 3C).

\section{Volg-3 sequence}

The sequence is present over much of the study area but is missing locally in the south-western part of the Salt Dome Province and in the area around the Mandal High, probably due to erosion (Fig. 20A). The lower sequence boundary is positioned at the top of a coars- ening-upwards interval (e.g. Elin-1, Gert-2; Fig.19). In a number of wells where the section is relatively thin, the sequence boundary is placed at the base of a somewhat coarser bed (e.g. Gwen-2; Fig. 19). The Volg-3 sequence consists of marine mudstones. The thickness of the sequence attains a maximum of $259 \mathrm{~m}$ in E-1. The primary depocentre in the Tail End Graben branches into the Arne-Elin Graben. Secondary depocentres are present in the Gertrud and Feda Grabens and in the Outer Rough Basin (Fig. 20A).

The LOD of Oligosphaeridium patulum in the lower part of this sequence in a number of wells (e.g. Deep Gorm-1, Elly-2, Falk-1, Gert-2, Gert-4, I-1, M-8, U-1, V-1) combined with the LOD of Occisucysta balia in the middle to upper part of the sequence in the Bo-1, Gert-2, Gwen-2 and Ravn-2 wells indicate a latest Early Volgian - middle Middle Volgian age for this sequence. This is supported by the LOD of Perisseiasphaeridium pannosum in the upper part of the sequence in Gert-1 and Gert-2 (Fig. 3C).

\section{Basin evolution}

In this depositional phase, the occurrence of rift pulses is reflected by syn-rift successions with fining-upwards log patterns separated by successions with overall coarsening-upwards patterns, as described from the Mesozoic of East Greenland by Surlyk (1978). A rift pulse in Late Kimmeridgian time is indicated by the asymmetric sed- 
iment distribution of the Kimm- 4 deposits in the Tail End Graben (Fig. 18A). Another pulse in the earliest Early Volgian is reflected by fining-upwards log patterns in the lower part of the Volg-1 sequence (e.g. G-1, Gert-4; Fig. 14) and by seismic data from the Tail End Graben (Møller \& Rasmussen 2003, this volume). A further rift pulse in the Early Volgian is interpreted from the abrupt change from low to high gamma-ray values immediately below the Volg-2 MFS (e.g. Gert-4, Nora-1; Figs 14, 16). The latter two rift pulses are recorded on seismic data from the Tail End Graben where they resulted in a rota-
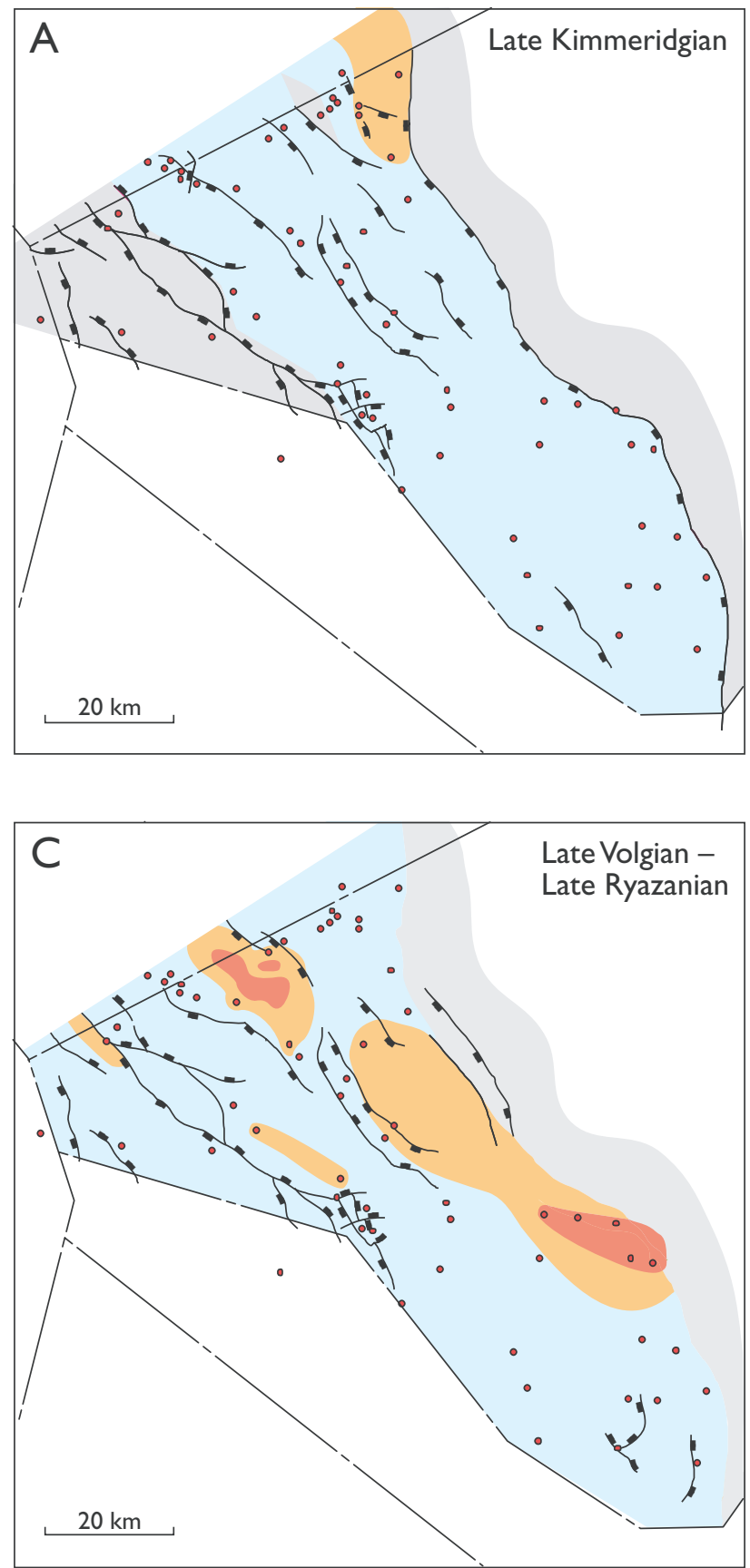

tional tilt package (Møller \& Rasmussen 2003, this volume, fig. 7).

The Tail End Graben and the Heno Plateau acted initially as one major asymmetric basin, with an elongate, NW-SE-oriented depocentre located in the Tail End Graben. During the Early Volgian, this depocentre expanded into the eastern part of the Søgne Basin, where subsidence increased significantly (Fig. 18A, B). The Feda Graben continued as an important depocentre. The Gertrud Graben and the Outer Rough and Ål Basins became actively subsiding elements at the time

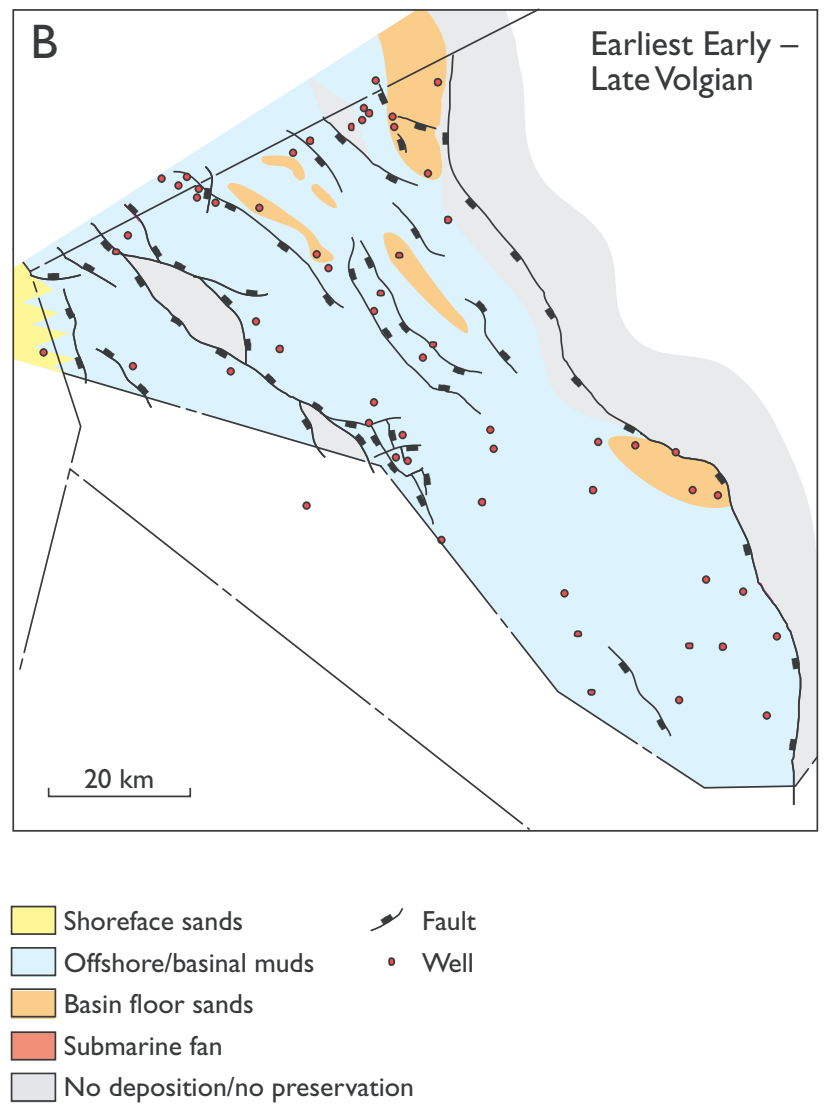

Fig. 21. Palaeogeographic maps for the Late Kimmeridgian Late Ryazanian. In the Early Volgian, the Outer Rough and Ål Basins were transgressed (compare $\mathbf{A}$ and $\mathbf{B}$ ). Fan and basin floor sandstones were deposited in deep parts of the basin during the Late Volgian - Ryazanian (C) 
of deposition of the Volg-2 sequence (Figs 17, 18C). Later during this phase, increased fault activity resulted in the generation of several minor sub-basins, for example the Arne-Elin Graben which became a distinct depocentre in the early Middle Volgian during deposition of the Volg-3 sequence (Figs 18C, 20A).

Plateau areas draped by Heno Formation sandstones were drowned and a coarsening-upwards succession of marine siltstones and mudstones of the Farsund Formation was deposited above the Kimm- 4 MFS (e.g. Ravn-1; Fig. 14). Thin storm- or gravity-derived sand layers were occasionally deposited in the Søgne Basin (Figs 17, 21A).

During the Early Volgian, the Outer Rough and Ål Basins were also transgressed, and fully marine conditions were established (Figs 17, 21B). Shoreface sands were deposited at the western margin of the Outer Rough Basin, as documented by data from the UK sector of the Central Graben (Mackertich 1996; Spathopoulos et al. 2000).

\section{Phase 7. Organic-rich mudstones and basin axis turbidites (late Middle Volgian - Early Ryazanian)}

\section{Sequence definitions}

\section{Volg-4 sequence}

This sequence has not been found in the Søgne Basin and Mandal High area; it is also missing from parts of the Outer Rough Basin and the Salt Dome Province. The sequence is present in all other parts of the study area (Fig. 20B). The lower boundary of the Volg- 4 sequence is positioned at the top of the well-defined coarseningupwards HST of the Volg-3 sequence below (e.g. Elin-1; Fig. 22). In a number of wells, the sequence boundary is further marked by the abrupt base of a slightly more silty or sandy unit (e.g. Jeppe-1).

In many wells (e.g. Iris-1, Jeppe-1), the lower part of the TST typically shows a fining-upwards/coarsening-upwards pattern; in V-1, this unit is developed as a $30 \mathrm{~m}$ thick sandstone unit (Fig. 23). In these wells, the remainder of the TST consists of a short, distinct fining-upwards mudstone section. In other wells, the TST is represented by a simple fining-upwards interval of marine mudstones (e.g. Bo-1, Elin-1; Fig. 22). The upper boundary of this sequence is commonly an erosion surface and the upper part of the HST is thus missing in many wells (e.g. Gwen-2, Jeppe-1; Figs 19, 22). Where a major part of the HST is preserved, it typically shows consistently high gammaray values (e.g. Bo-1, Elin-1). Due to the increasingly organic-rich nature of the sediments (see below), the gamma-ray log is not considered a fully reliable grain-size indicator. Despite the high gammaray readings, descriptions of the cuttings indicate the presence of sand- and siltstone in this interval. It is therefore assumed that the high gamma-ray readings are caused by the presence of organic-rich 'hot shales' and not necessarily by a lack of sand- and silt-sized material. The sequence consists of marine, organic-rich mudstone with silt- and sandstone interbeds. The thickness of the sequence attains a maximum of $189 \mathrm{~m}$ in Elin-1. The sequence shows a more even distribution than the previous sequences, but depocentres are still recognisable in the Tail End Graben, the Arne-Elin Graben, the Feda Graben and the Outer Rough Basin (Fig. 20B).

The LOD of Scriniodinium inritibile in the lower part of the sequence in Bo-1 and of Senoniasphaera jurassica in the lower to middle part of the sequence in a number of wells (e.g. Bo-1, Deep Gorm-1, Elin-1, Gwen-2, I-1, Jeppe-1, Ravn-2, W-1) indicate a middle Middle Volgian age for the lower part of the sequence. In combination with the LOD of Egmontodinium polyplacophorum in the middle to upper part of the sequence in the Bo-1, Deep Adda-1, E-1, I-1, Lone-1 and V-1 wells, this indicates a middle Middle Volgian to Late Volgian age for the sequence. This age assumption is supported by the LOD of one or more of the dinocyst species Dichadogonyaulax pannea, Glossodinium dimorphum, Muderongia simplex (the form previously referred as Muderongia sp. A; Poulsen \& Riding 2003, this volume) and Gochteodinia mutabilis within the sequence in a number of wells (e.g. Bo-1, Deep Gorm-1, E-1, Elin-1, Gwen-2, I-1, Iris-1, V-1; Fig. 3C).

\section{Ryaz-1 sequence}

The distribution of the Ryaz-1 sequence corresponds to the distribution of the Volg-4 sequence (see above). The development of the 'hot shales' of the Bo Member within this sequence and the transition to more calcareous sediments at the top of the Farsund Formation makes sequence stratigraphic analysis problematic. Neither a MFS nor an upper boundary of the sequence have been picked. The sequence is not necessarily limited to the marine mudstones of the Farsund Formation but may straddle the boundary to the overlying Cromer Knoll Group. The lower sequence boundary is normally distinct and often erosional (e.g. Bo-1, Elin-1, Jeppe-1; Fig. 22). Turbidite sandstones occur above the boundary in several wells (e.g. Iris-1, Jeppe-1; Fig. 23). In certain wells that lack such turbidite sandstones (e.g. E-1, Gert-2), the bioevents of the turbidite-bearing section are absent; this hiatus is interpreted to have resulted from erosion or sediment bypass, updip from areas in which turbidite sands accumulated (Ineson et al. 2003, this volume).

The turbidite interval may represent lowstand and possibly early transgressive deposits. In areas without active turbidite transport or deposition, this interval is characterised by a gradual upwards increase in gamma-ray values, probably representing the background sedimentation of the basin (e.g. Bo-1). This increase in the strength of the gammaray signal culminates in the highest gamma-ray values in the entire Jurassic studied section. This interval corresponds to the 'hot unit' of Jensen et al. (1986), formalised as the Bo Member (Farsund Formation) by Michelsen et al. (2003, this volume). The dominant lithology is 


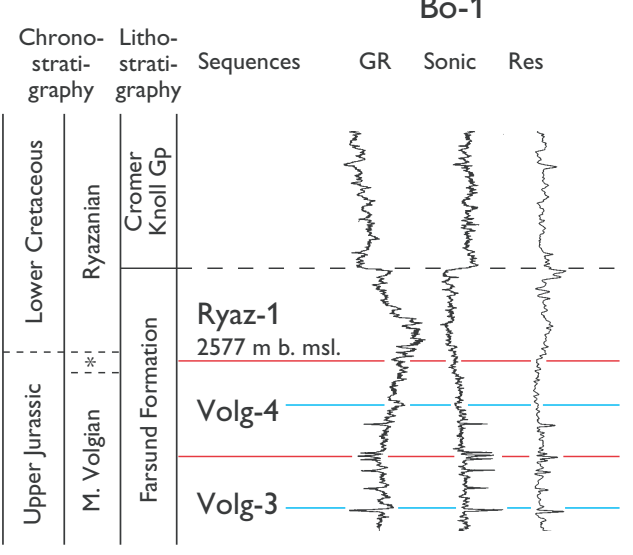

* Upper Volgian

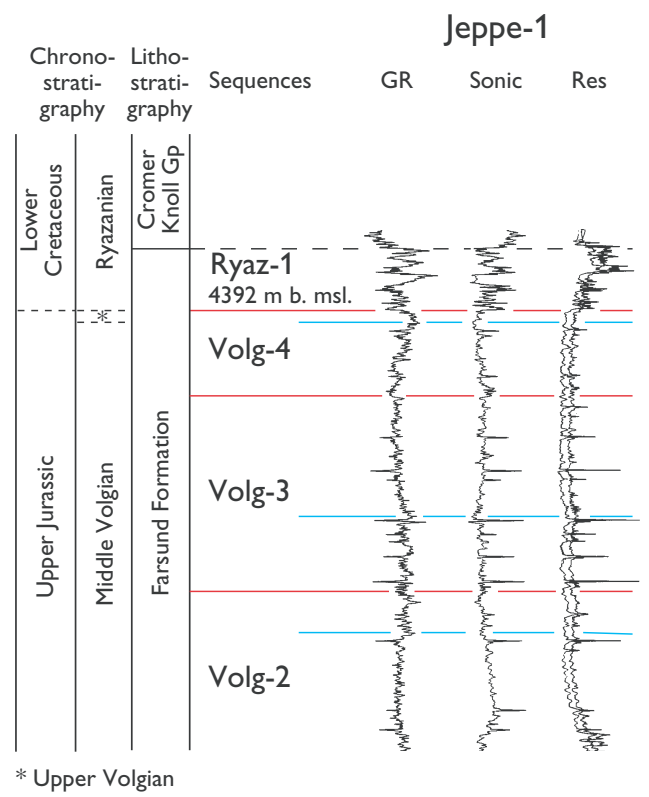

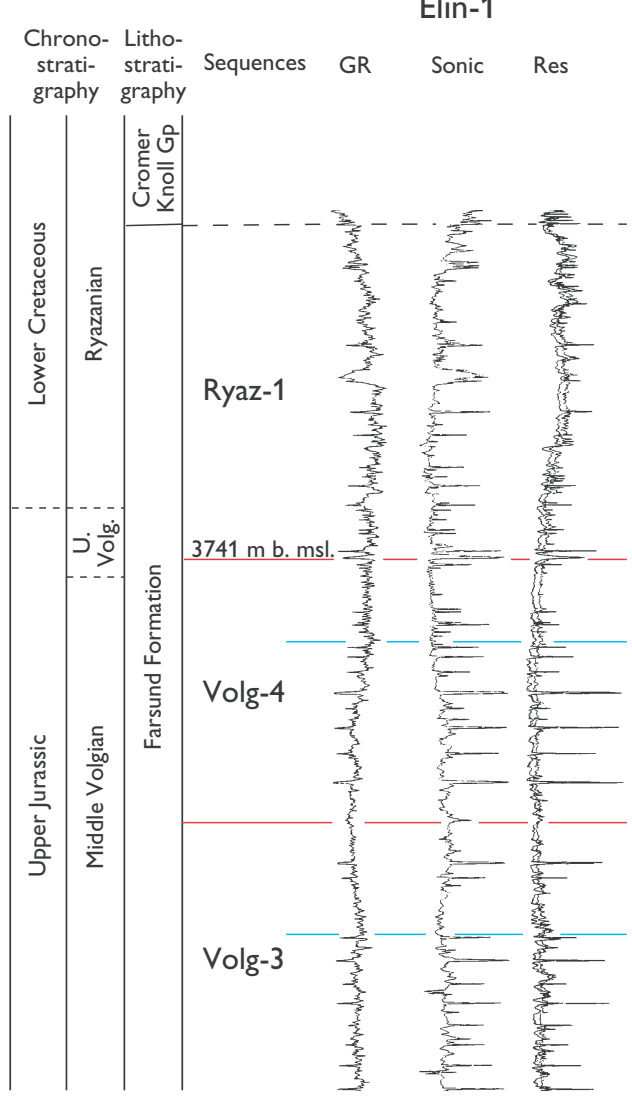

Maximum flooding surface Sequence boundary

Fig. 22. Uppermost Jurassic to lowermost Cretaceous stratigraphy of the Bo-1, Elin-1 and Jeppe-1 wells illustrating the characteristic features of the Volg-4 - Ryaz-1 sequences. M., Middle; U. Volg., Upper Volgian.

organic-rich marine mudstone; the mudstones are locally interbedded with turbidite sandstones (Ineson et al. 2003, this volume).The thickness of this interval, from the basal sequence boundary to the top of the Farsund Formation, attains a maximum of $326 \mathrm{~m}$ in Iris-1.

The LOD of Egmontodinium expiratum in the lower part of this sequence in a number of wells (e.g. Bo-1, Edna-1, Gert-2) and of Rotosphaerotopsis thula immediately above the 'hottest' part of the Bo Member (e.g. in Anne-3, Bo-1, E-1, Edna-1, Gert-2, Jeppe-1) indicate a Late Volgian - Early Ryazanian age for this part of the sequence. The uppermost part of the Farsund Formation is of Late Ryazanian age. This is indicated by the LOD of Dingodinium spinosum which coincides broadly with the upper boundary of the Farsund Formation in a number of wells (e.g. Deep Gorm-1, E-1, Edna-1, Jens-1, Jeppe-1,
Kim-1, Lone-1, V-1; Ineson et al. 2003, this volume) and by the LOD of Dichadogonyaulax culmula at the same stratigraphic level in the E-1, Edna-1 and Gert-2 wells (Fig. 3C).

\section{Basin evolution}

The rate of subsidence decreased in the Tail End Graben and the Salt Dome Province during this phase; in combination with decreased sediment supply, this resulted in stratigraphic condensation. According to the time-scale of Gradstein et al. (1994), the succession deposited during phase 7 represents a period of $c .5 .5$ million years, 


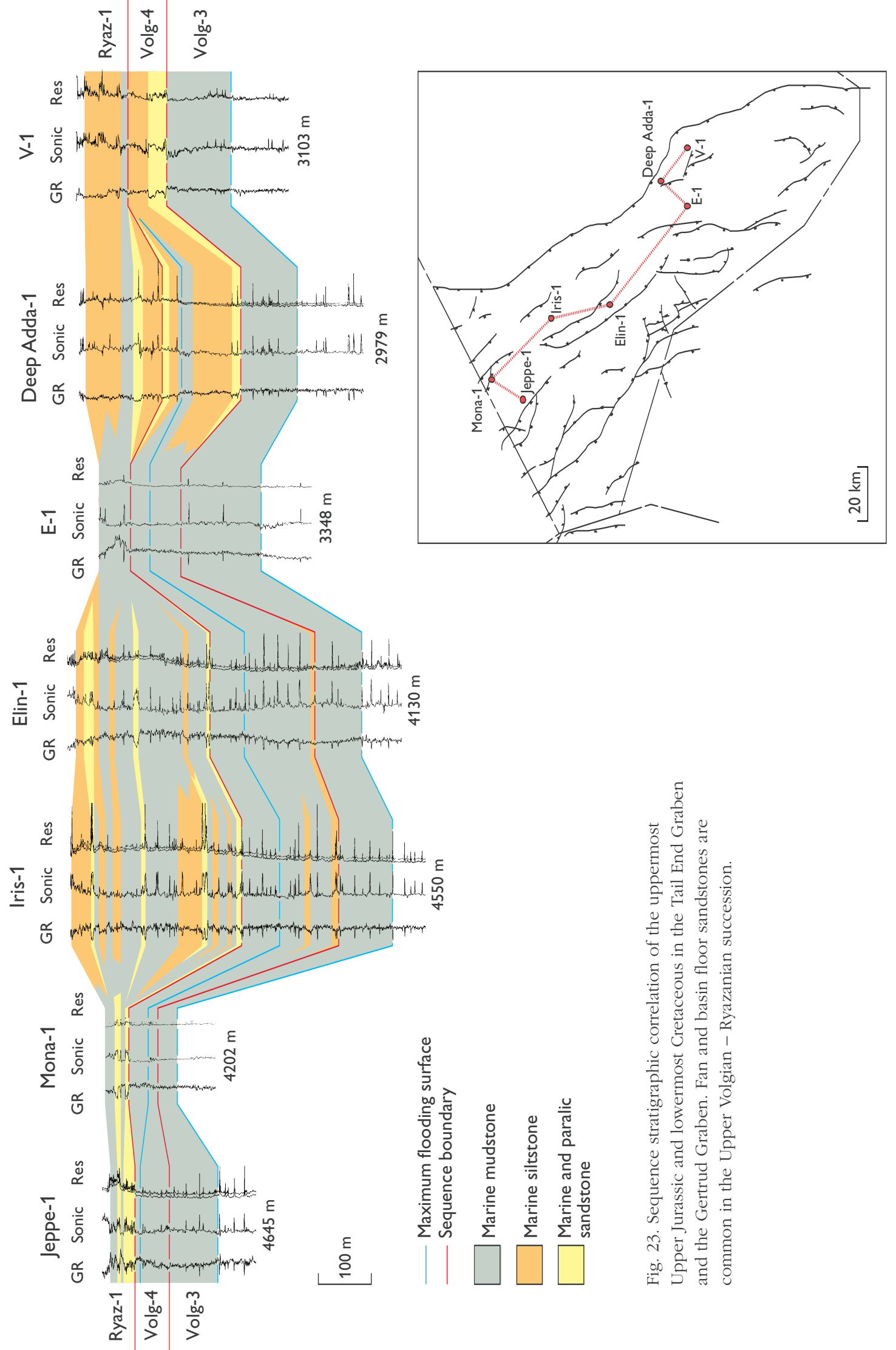


approximately equal to the time represented by the 2-10 times thicker succession of phase 6 .

Fault activity ceased along large segments of the main boundary fault (Møller \& Rasmussen 2003, this volume), and this caused the geometry of the Tail End Graben to change from an asymmetric rift to a more symmetrical saucer-like basin with a relatively uniform sediment distribution (Fig. 20B). These changes are the first indications in the Tail End Graben of the beginning of an early post-rift stage. Minor depocentres continued to exist in the northern part of the Tail End Graben and in the Arne-Elin Graben. Subsidence continued in the Feda Graben and in the Outer Rough Basin.

The deposits of phase 7 consist of marine mudstones of the Farsund Formation. They generally show a gradual increase in gamma-ray and TOC values culminating in the 'hot shales' of the Bo Member in the uppermost part (Figs 17, 23; Jensen et al. 1986; Ineson et al. 2003, this volume). Below the Bo Member, a well-developed sequence boundary separates the Volg- 4 and Ryaz-1 sequences. This sequence boundary is strongly erosional in most wells on the northern part of the Heno Plateau and along the southern margin of the Feda and Gertrud Grabens (e.g. Jeppe-1; Fig. 17). Above the sequence boundary, sandstones are present in a number of wells along the basin axes of the Tail End Graben and the Gertrud Graben (Figs 21C, 23). The sandstones were deposited from turbidity currents (Iris-1) and debris flows (Jeppe-1) and may have originated from a number of sources, such as the East North Sea Block of the Ringkøbing-Fyn High, the Mandal High and the Gert Ridge (Nielsen 1985; Ineson et al. 2003, this volume). Their occurrence may be related to changed drainage patterns in the hinterland after subsidence had ceased along major segments of the main boundary fault, and to erosion of inverted structures or crests of rotated fault blocks.

\section{Relative sea-level changes}

On the basis of the sequence stratigraphic framework presented here (Fig. 24), a relative sea-level curve can be constructed for the Middle-Late Jurassic time interval and compared with eustatic curves proposed by Haq et al. (1988) and Hallam (1988) based on North Sea and global data and with the relative sea-level curve of Surlyk (1990) for East Greenland (Fig. 25). The Lower Jurassic has only been penetrated by wells in a small part of the study area, and no attempt has been made to construct a sea-level curve for this part of the suc- cession. Data are lacking from the Toarcian and most of the Aalenian due to the regional uppermost Aalenian or lowermost Bajocian unconformity. Good biostratigraphic datings become available from the uppermost Bathonian-Callovian and upwards; the sea-level curve thus has its starting point at this level. Wells from the basin centre and intermediate positions were preferred in selecting data for the construction of the curve.

The relative sea-level changes have been interpreted mainly from lithological changes (e.g. changes in mud content in marine sediments) reflecting bathymetrically related changes in energy level. Lithological changes were interpreted from well log patterns and cores. Sedimentary facies, palynofacies and the extent of marine flooding surfaces have also been used.

High uranium contents in some marine mudstones, related to organic matter content rather than clay proportion, can cause large deflections on the well logs, thus hampering lithological interpretation. For that reason, sea-level interpretations were not attempted in the 'hot shales' of the Bo Member.

The coastal plain deposits of latest Bathonian - earliest Callovian age were transgressed during the Callovian - earliest Oxfordian in most of the Danish Central Graben. A relative sea-level rise caused a rapid, step-wise transgression that expanded the basin laterally and drowned previous sediment sources. The sea-level rise and transgression continued throughout the Oxfordian and culminated in the Early Kimmeridgian. This development, from the latest Bathonian to the late Early Kimmeridgian, is almost identical to the sea-level curves of Haq et al. (1988) and Hallam (1978, 1981, 1988), based on North Sea and global data, and the curve of Surlyk (1990) for East Greenland. The gradual collapse of the North Sea Dome (Hallam \& Sellwood 1976; Ziegler 1982; Underhill \& Partington 1993) and the initiation of rifting in the Danish Central Graben may have influenced transgressive trends in the region during this period. However, the resemblance between the relative sea-level curve of this study and the curves of Haq et al. (1988), Hallam (1988) and Surlyk (1990) may indicate that a common causal factor of super-regional or global extent also influenced sea-level changes during this interval.

The uppermost Lower Kimmeridgian - Upper Kimmeridgian of the Danish Central Graben is characterised by a double lowstand peak. The other sea-level curves are close to their maximum at this level. The lowstand in the Danish Central Graben probably evolved as a result of a sea-level fall during a pause in rift-induced subsidence (phase 5). 

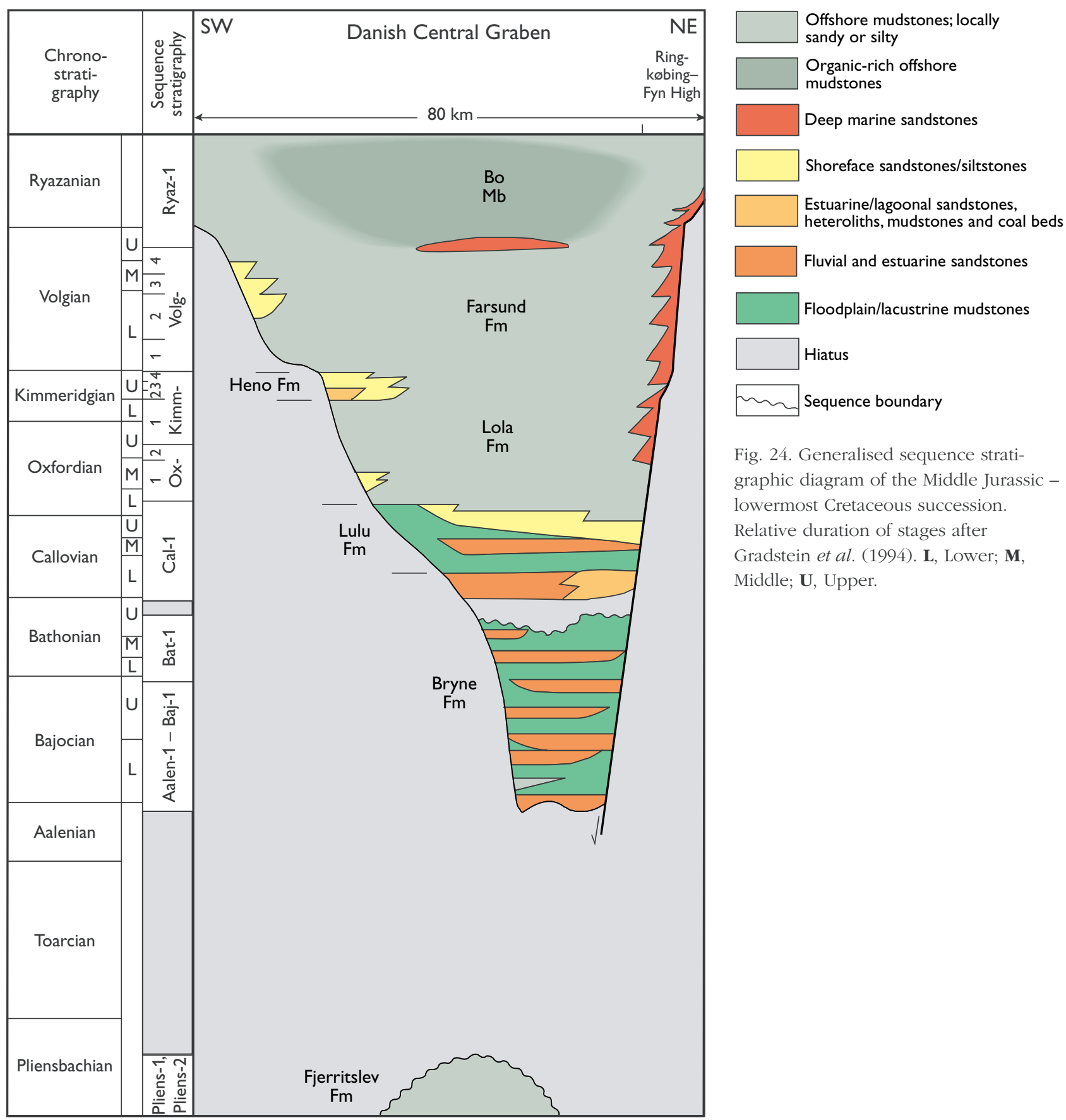

Fig. 24. Generalised sequence stratigraphic diagram of the Middle Jurassic lowermost Cretaceous succession. Relative duration of stages after Gradstein et al. (1994). L, Lower; $\mathbf{M}$, Middle; $\mathbf{U}$, Upper.

After the lowstand event, the Late Kimmeridgian late Middle Volgian interval shows an overall rise in relative sea level, interrupted by a number of minor falls. This overall trend differs from the fall seen in most of the other sea-level curves, probably due to the continued high subsidence rate in the Danish Central Graben, which neutralised the effect of the global sea-level fall indicated by the other curves. The minor relative sealevel falls in the interval may reflect pauses between periods of active subsidence.

\section{Lithology prediction}

An important reason for undertaking a sequence stratigraphic study of a hydrocarbon-producing basin is to improve lithology and reservoir prediction. The predictive potential in syn-rift units is much less than in post-rift units. This is due to the problems for orderly sediment dispersal caused by the creation of tilted fault blocks and sub-basins, by the continuous presence of accommodation space on the lower hanging-wall slopes of tilted fault blocks, and by the local supply of sand 


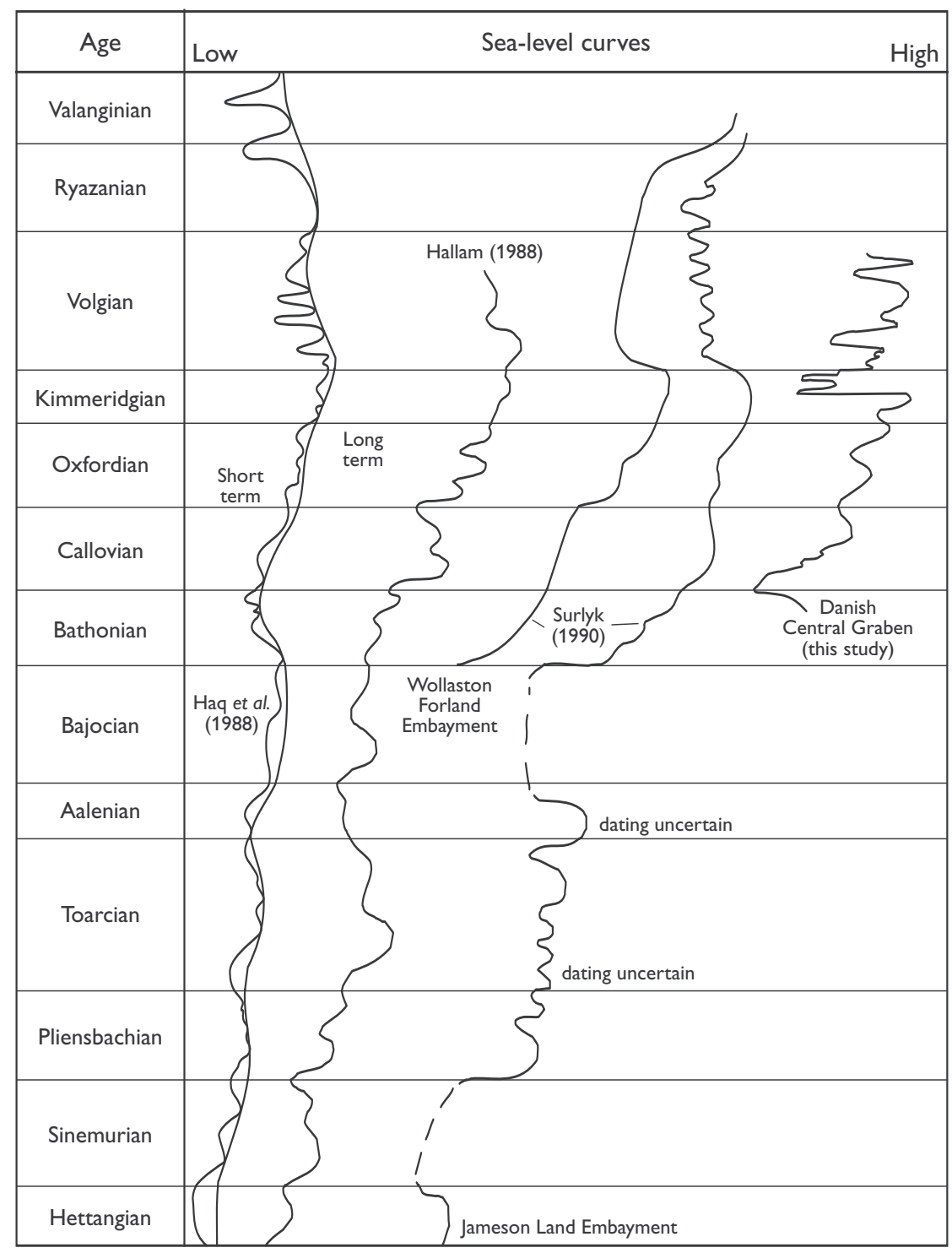

Fig. 25. Comparison of the relative sealevel curve of this study with the sealevel curves presented by Haq et al. (1988), Hallam (1988) and Surlyk (1990). Figure modified after Surlyk (1990), according to the Gradstein et al. (1994) time-scale. from erosion of uplifted footwall shoulders. However, in the Middle to Upper Jurassic syn-rift deposits of the Danish Central Graben, the sandstone units seem to show a systematic distribution, which may be related to the combination of sea-level changes and periods of little tectonic subsidence.

The Bathonian-Callovian sandstones, that are widely distributed in the Søgne Basin, the Tail End Graben and the Salt Dome Province, resulted from a generous supply of sand from the active denudation of the North Sea dome area and a relatively low and only slowly increasing accommodation space in the rift initiation stage. The best reservoir sandstones occur in the lowstand and transgressive systems tracts of the Baj-1, Bat- 1 and Cal-1 sequences (Figs 4, 7), in the form of laterally extensive fluvial channel sandstones and tidal and shoreface sandstones in the uppermost part of the sandstone unit, deposited prior to the final transgression. The desirable combination of large fluvial and tidal channels and extensive wave-reworked sandstones occurs in the deeper parts of the Søgne Basin and the Tail End Graben. In these areas, subsidence was sufficiently fast to create accommodation space for successions of wave-influenced sediments up to $30 \mathrm{~m}$ thick during the final Middle Jurassic transgression (Andsbjerg 2003, this volume).

An overall transgressive development is interpreted for the Late Jurassic. The largest concentration of reservoir sandstones in this succession (the Heno Formation) was deposited during a pause in the otherwise rapid subsidence. The sand is concentrated on the Heno Plateau, the Gertrud Plateau and along the southern margin of the Feda Graben. The Heno Plateau constituted an upper hanging-wall slope of a major half-graben, the Tail End Graben, and the Gertrud Plateau probably 
comprised a transfer zone between the Tail End and Feda Grabens (Figs 11, 13, 14). Possible source areas for the sandstones were to the north-east, where the Ula Formation and Bryne Formation sandstones were located, and to the west, on the Mid North Sea High (Figs 15B, C). Fluvial systems and/or marine current and wave activity may have facilitated sediment transport to the Gertrud and Heno Plateaus. A similar scenario was envisaged by Howell et al. (1996) for the southern UK Central Graben.

The turbidite and debris flow sandstones of the Upper Volgian - Ryazanian constitute potential reservoirs (Fig. 23). Most of the sands were deposited during depositional phase 7 , when subsidence had decreased, and parts of the Danish Central Graben had broken up into fault-bounded sub-basins. Inactivity of some Coffee Soil Fault segments (Møller \& Rasmussen 2003, this volume) may have increased the drainage area in the marginal hinterland and opened new sediment transport routes, causing an increased sand supply. Sediment dispersal in the receiving basin was still hampered by a topography dominated by tilted fault blocks and many small subbasins. The most extensive sandstones are present immediately above the Ryaz- 1 basal sequence boundary.

Sandstones have not been encountered in the few released wells drilled in the Danish part of the Outer Rough and Ål Basins. However, the presence of Volgian reservoir sandstones of a type similar to the Heno Formation is reported from wells nearby in the UK sector (Mackertich 1996; Spathopoulos et al. 2000).

\section{Conclusions}

The depositional history of the Danish Central Graben in the Jurassic shows a relationship to contemporaneous rift stages and to relative and eustatic sea-level changes. The basin development in the Jurassic is subdivided into seven depositional phases that reflect this interplay:

Phase 1 (Hettangian-Pliensbachian). During phase 1 , pre-rift marine mudstones were deposited in a stable epicontinental sea, that stretched across a major part of the North Sea region. The deposits were removed from large parts of the central North Sea region by subsequent erosion (phase 2).

Phase 2 (latest Pliensbachian - latest Aalenian/earliest Bajocian). This corresponds to the tectonic protorift stage, being characterised by domal uplift and regionally extensive erosion.
Phase 3 (latest Aalenian/earliest Bajocian - Late Callovian). The Middle Jurassic sandstones owe their presence to erosion of the North Sea dome, and to slow generation of accommodation space during initial rifting (initiation of the tectonic rift stage). Subsidence rates increased in the Callovian and Oxfordian, heralding the onset of the climax of the tectonic rift stage. This resulted in marine flooding and cessation of sand deposition.

Phase 4 (Early Oxfordian - Early Kimmeridgian). In the Oxfordian - Early Kimmeridgian, the Tail End Graben entered the rift climax resulting in the development of a half-graben. Marine mudstones were deposited during this phase.

Phase 5 (Late Kimmeridgian). Extensive sand deposition took place in the early Late Kimmeridgian during a halt in subsidence between two rift pulses. Sand was deposited over a large area with low accommodation space, which was created on the hangingwall plateau. Exposed highs and land areas outside the graben supplied the sand. Due to the decrease in subsidence in the Tail End Graben, input of finegrained sediment could catch up with accommodation space generation, probably resulting in a flat topography at the end of this phase.

Phase 6 (latest Late Kimmeridgian - middle Middle Volgian). During this phase, renewed rifting caused rapid subsidence in the study area. Several rift pulses occurred during this interval. Due to the high overall rate of subsidence, sand deposition associated with relative sea-level falls did not occur. The Danish Central Graben began to break up into minor subbasins during this phase.

Phase 7 (late Middle Volgian - Ryazanian). Subsidence decreased over large areas of the basin, which had probably entered an early post-rift stage. Major segments of the Coffee Soil Fault became inactive, resulting in a shallower, more symmetrical basin. Active subsidence continued in a number of subbasins. Highly organic-rich mudstones are prominent in the deposits of this phase. The mudstones are interbedded with turbidite and debris flow sand deposits locally, in particular along the Tail End Graben - Gertrud Graben basin axis and along the eastern margin of the Tail End Graben. 
Comparison of the sea-level curve constructed for the Danish Central Graben with published sea-level curves indicates that deposition in the periodically very rapidly subsiding rift basin was strongly influenced by tectonics. In the latest Bathonian - late Early Kimmeridgian, the overall deepening trend resulted from both eustatic sea-level rise and rift-related subsidence. During the rest of the Late Jurassic, the deepening trend was primarily related to the high subsidence rate associated with rifting. Most sediments were deposited between rift pulses in accomodation space that was generated during the rift pulses or by passive subsidence; only a relatively minor proportion of the sediments was deposited during the rift pulses.

\section{Acknowledgements}

We had fruitful discussions with colleagues Jon R. Ineson, Peter N. Johannessen, Jens J. Møller and Erik S. Rasmussen. We gratefully acknowledge the comments of Jon R. Ineson and Erik S. Rasmussen on an early manuscript and those of the two referees, M.J. Fisher and D.N. Parkinson. The work formed part of a Ph.D. study at Copenhagen University for the first author, who extends his gratitude to supervisor Finn Surlyk for his thorough and critical comments. Eva B. Koppelhus and Niels E. Poulsen kindly supplied us with palynological datings. The work was supported by the Danish Energy Agency (EFP-92, 1313/920002), Mærsk Oil and Gas A/S and Norsk Hydro Udforskning a.s./Amerada Hess A/S.

\section{References}

Andersen, C., Olsen, J.C., Michelsen, O. \& Nygaard, E. 1982: Structural outline and development. In: Michelsen, O. (ed.): Geology of the Danish Central Graben. Danmarks Geologiske Undersøgelse Serie B 8, 9-26.

Andsbjerg, J. 2003: Sedimentology and sequence stratigraphy of the Bryne and Lulu Formations, Middle Jurassic, northern Danish Central Graben. In: Ineson, J.R. \& Surlyk, F. (eds): The Jurassic of Denmark and Greenland. Geological Survey of Denmark and Greenland Bulletin 1, 301-347 (this volume).

Birkelund, T., Clausen, C.K., Hansen, H.N. \& Holm, L. 1983: The Hectoroceras kochi zone (Ryazanian) in the North Sea Central Graben and remarks on the Late Cimmerian Unconformity. Danmarks Geologiske Undersøgelse Årbog 1982, 53-72.

Blair, T.C. \& Bilodeau, W.L. 1988: Development of tectonic cyclothems in rift, pull-apart, and foreland basins: sedimentary response to episodic tectonism. Geology 16, 517-520.

Cartwright, J.A. 1987: Transverse structural zones in continental rifts - an example from the Danish sector of the North Sea. In: Brooks, J. \& Glennie, K.W. (eds): Petroleum geology of
North West Europe, 441-452. London: Graham \& Trotman. Cartwright, J.A. 1991: The kinematic evolution of the Coffee Soil Fault. In: Roberts, A.M., Yielding, G. \& Freeman, B. (eds): The geometry of normal faults. Geological Society Special Publication (London) 56, 29-40.

Costa, L.I. \& Davey, R.J. 1992: Dinoflagellate cysts of the Cretaceous System. In: Powell, A.J. (ed.): A stratigraphic index of dinoflagellate cysts, 99-153. British Micropalaeontological Society Publication Series. London: Chapman \& Hall.

Davey, R.J. 1979: The stratigraphic distribution of dinocysts in the Portlandian (latest Jurassic) to Barremian (Early Cretaceous) of Northwest Europe. American Association of Stratigraphic Palynologists Contributions Series 5B, 49-81.

Dybkjær, K. 1988: Palynological zonation and stratigraphy of the Jurassic section in the Gassum No.1-borehole. Danmarks Geologiske Undersøgelse Serie A 21, 73 pp.

Dybkjær, K. 1991: Palynological zonation and palynofacies investigation of the Fjerritslev Formation (Lower Jurassic - basal Middle Jurassic) in the Danish Subbasin. Danmarks Geologiske Undersøgelse Serie A 30, 150 pp.

Eynon, G. 1981: Basin development and sedimentation in the Middle Jurassic of the northern North Sea. In: Illing, L.V. \& Hobson, G.D. (eds): Petroleum geology of the continental shelf of North-West Europe, 196-204. London: Heyden \& Son Ltd.

Fenton, P.G. \& Riding, J.B. 1987: Kekryphalospora distincta gen. et sp. nov., a trilete spore from the Lower and Middle Jurassic of North-West Europe. Pollen et Spores 29, 427-434.

Gabrielsen, R.H., Færseth, R.B., Steel, R.J., Idil, S. \& Kløvjan, O.S. 1990: Architectural styles of basin fill in the northern Viking Graben. In: Blundell, D.J. \& Gibbs, A.D. (eds): Tectonic evolution of the North Sea rifts, 158-179. Oxford: Clarendon Press.

Gowers, M.B. \& Sæbøe, A. 1985: On the structural evolution of the Central Trough in the Norwegian and Danish sectors of the North Sea. Marine and Petroleum Geology 2, 298-318.

Gradstein, F.M., Agterberg, F.P., Ogg, J.G., Hardenbol, J., van Veen, P., Thierry, J. \& Huang, Z. 1994: A Mesozoic time scale. Journal of Geophysical Research 99, 24051-24074.

Hallam, A. 1978: Eustatic cycles in the Jurassic. Palaeogeography, Palaeoclimatology, Palaeoecology 23, 1-32.

Hallam, A. 1981: A revised sea-level curve for the early Jurassic. Journal of the Geological Society (London) 138, 735-743.

Hallam, A. 1988: A reevaluation of Jurassic eustasy in the light of new data and the revised Exxon curve. In: Wilgus, C.K. et al. (eds): Sea-level change - an integrated approach. Society of Economic Paleontologists and Mineralogists Special Publication 42, 261-273.

Hallam, A. \& Sellwood, B.W. 1976: Middle Mesozoic sedimentation in relation to tectonics in the British area. Journal of Geology 84, 301-321.

Haq, B.U., Hardenbol, J. \& Vail, P.R. 1988: Mesozoic and Cenozoic chronostratigraphy and cycles of sea-level change. In: Wilgus, C.K. et al. (eds): Sea-level changes - an integrated approach. Society of Economic Paleontologists and Mineralogists Special Publication 42, 71-108.

Heilmann-Clausen, C. 1987: Lower Cretaceous dinoflagellate biostratigraphy in the Danish Central Trough. Danmarks Geologiske Undersøgelse Serie A 17, 89 pp. 
Hoelstad, T. 1986: Palynology of the Middle Jurassic Lower Graben Sand Formation of the U-1 well, Danish Central Trough. Danmarks Geologiske Undersøgelse Serie A 14, 25 pp.

Howell, J.A., Flint, S.S. \& Hunt, C. 1996: Sedimentological aspects of the Humber Group (Upper Jurassic) of the South Central Graben, UK North Sea. Sedimentology 43, 89-114.

Hunt, D. \& Tucker, M.E. 1992: Stranded parasequences and the forced regressive wedge systems tract: deposition during baselevel fall. Sedimentary Geology $\mathbf{8 1}, 1-9$.

Hunt, D. \& Tucker, M.E. 1995: Stranded parasequences and the forced regressive wedge systems tract: deposition during baselevel fall - reply. Sedimentary Geology 95, 147-160.

Ineson, J.R., Bojesen-Koefoed, J.A., Dybkjær, K. \& Nielsen, L.H. 2003: Volgian-Ryazanian 'hot shales' of the Bo Member (Farsund Formation) in the Danish Central Graben, North Sea: stratigraphy, facies and geochemistry. In: Ineson, J.R. \& Surlyk, F. (eds): The Jurassic of Denmark and Greenland. Geological Survey of Denmark and Greenland Bulletin 1, 403-436 (this volume)

Jensen, T.F., Holm, L., Frandsen, N. \& Michelsen, O. 1986: Jurassic - Lower Cretaceous lithostratigraphic nomenclature for the Danish Central Trough. Danmarks Geologiske Undersøgelse Serie A 12, 65 pp.

Johannessen, P.N. 2003: Sedimentology and sequence stratigraphy of paralic and shallow marine Upper Jurassic sandstones in the northern Danish Central Graben. In: Ineson, J.R. \& Surlyk, F. (eds): The Jurassic of Denmark and Greenland. Geological Survey of Denmark and Greenland Bulletin 1, 367-402 (this volume)

Johannessen, P.N. \& Andsbjerg, J. 1993: Middle to Late Jurassic basin evolution and sandstone reservoir distribution in the Danish Central Trough. In: Parker, J.R. (ed.): Petroleum geology of Northwest Europe: proceedings of the 4th conference, 271-283. London: Geological Society.

Johannessen, P.N., Dybkjær, K. \& Rasmussen, E.S. 1996: Sequence stratigraphy of Upper Jurassic reservoir sandstones in the northern part of the Danish Central Trough, North Sea. Marine and Petroleum Geology 13, 755-770.

Koch, J.-O. 1983: Sedimentology of Middle and Upper Jurassic sandstone reservoirs of Denmark. In: Kaasschieter, J.P.H. \& Reigers, T.J.A. (eds): Petroleum geology of the southeastern North Sea and the adjacent onshore areas. Geologie en Mijnbouw 62 , 115-129.

Koppelhus, E.B. \& Nielsen, L.H. 1994: Palynostratigraphy and palaeoenvironments of the Lower to Middle Jurassic Bagå Formation of Bornholm, Denmark. Palynology 18, 139-194.

Korstgård, J.A., Lerche, I., Mogensen, T.E. \& Thomsen, R.O. 1993: Salt and fault interactions in the northeastern Danish Central Graben: observations and inferences. Bulletin of the Geological Society of Denmark 40, 197-255.

Larsen, G. 1966: Rhaetic - Jurassic - Lower Cretaceous sediments in the Danish Embayment (a heavy-mineral study). Danmarks Geologiske Undersøgelse II. Række 91, 128 pp.

Lund, J.J. 1977: Rhaetic to Lower Liassic palynology of the onshore south-eastern North Sea Basin. Danmarks Geologiske Undersøgelse II. Række 109, 129 pp.

Mackertich, D. 1996: The Fife Field, UK Central North Sea.
Petroleum Geoscience 2, 373-380.

Michelsen, O. 1978: Stratigraphy and distribution of Jurassic deposits of the Norwegian-Danish Basin. Danmarks Geologiske Undersøgelse Serie B 2, 28 pp.

Michelsen, O. (ed.) 1982: Geology of the Danish Central Graben. Danmarks Geologiske Undersøgelse Serie B 8, 133 pp.

Michelsen, O. 1989: Log-sequence analysis and environmental aspects of the Lower Jurassic Fjerritslev Formation in the Danish Subbasin. Danmarks Geologiske Undersøgelse Serie A 25, 23 pp.

Michelsen, O., Frandsen, N., Holm, L., Jensen T.F., Møller, J.J. \& Vejbæk, O.V. 1987: Jurassic - Lower Cretaceous of the Danish Central Trough; depositional environments, tectonism, and reservoirs. Danmarks Geologiske Undersøgelse Serie A 16, 45 pp.

Michelsen, O., Nielsen, L.H., Johannessen, P.N., Andsbjerg, J. \& Surlyk, F. 2003: Jurassic lithostratigraphy and stratigraphic development onshore and offshore Denmark. In: Ineson, J.R. \& Surlyk, F. (eds): The Jurassic of Denmark and Greenland. Geological Survey of Denmark and Greenland Bulletin 1, 147-216 (this volume).

Mogensen, T.E., Korstgaard, J.A. \& Geil, K. 1992: Salt tectonics and faulting in the NE Danish Central Graben. In: Spencer, A.M. (ed.): Generation, accumulation and production of Europe's hydrocarbons II. European Association of Petroleum Geoscientists Special Publication 2, 163-173.

Møller, J.J. 1986: Seismic structural mapping of the Middle and Upper Jurassic in the Danish Central Trough. Danmarks Geologiske Undersøgelse Serie A 13, 37 pp.

Møller, J.J. \& Rasmussen, E.S. 2003: Middle Jurassic - Early Cretaceous rifting of the Danish Central Graben. In: Ineson, J.R. \& Surlyk, F. (eds): The Jurassic of Denmark and Greenland. Geological Survey of Denmark and Greenland Bulletin $\mathbf{1}$, 247-264 (this volume).

Nielsen, L.H. 1985: Central Graben core description report 5604/301. Description of cores 2-6. Geological Survey of Denmark Confidential report 7, $13 \mathrm{pp}$.

Nielsen, L.H. 2003: Late Triassic - Jurassic development of the Danish Basin and the Fennoscandian Border Zone, southern Scandinavia. In: Ineson, J.R. \& Surlyk, F. (eds): The Jurassic of Denmark and Greenland. Geological Survey of Denmark and Greenland Bulletin 1, 459-526 (this volume).

Nøttvedt, A., Gabrielsen, R.H. \& Steel, R.J. 1995: Tectonostratigraphy and sedimentary architecture of rift basins, with reference to the northern North Sea. Marine and Petroleum Geology 12, 881-901.

Pedersen, G.K. 1985: Thin, fine-grained storm layers in a muddy shelf sequence: an example from the Lower Jurassic in the Stenlille 1 well, Denmark. Journal of the Geological Society (London) 142, 357-374.

Pedersen, G.K. 1986: Changes in the bivalve assemblage of an Early Jurassic mudstone sequence (the Fjerritslev Formation in the Gassum 1 well, Denmark). Palaeogeography, Palaeoclimatology, Palaeoecology 53, 139-168.

Posamentier, H.W. \& Vail, P.R. 1988: Eustatic controls on clastic deposition II - sequence and systems tract models. In: Wilgus, C.K. et al. (eds): Sea-level changes - an integrated approach. Society of Economic Paleontologists and Mineralogists Special 
Publication 42, 125-154.

Posamentier, H.W. \& James, D.P. 1993: An overview of sequencestratigraphic concepts: uses and abuses. In: Posamentier, H.W. et al. (eds): Sequence stratigraphy and facies associations. International Association of Sedimentologists Special Publication 18, 3-18.

Posamentier, H.W., Jervey, M.T. \& Vail, P.R. 1988: Eustatic controls on clastic deposition I - conceptual framework. In: Wilgus, C.K. et al. (eds): Sea-level changes - an integrated approach. Society of Economic Paleontologists and Mineralogists Special Publication 42, 109-124.

Poulsen, N.E. 1986: Callovian-Volgian dinocyst stratigraphy of the Central Trough in the Danish North Sea area. Bulletin of the Geological Society of Denmark 35, 1-10.

Poulsen, N.E. 1991: Upper Jurassic dinocyst stratigraphy in the Danish Central Trough. In: Michelsen, O. \& Frandsen, N. (eds): The Jurassic of the southern Central Trough. Danmarks Geologiske Undersøgelse Serie B 16, 7-15.

Poulsen, N.E. 1992: Jurassic dinoflagellate cyst biostratigraphy of the Danish Subbasin in relation to sequences in England and Poland; a preliminary review. Review of Palaeobotany and Palynology 75, 33-52.

Poulsen, N.E. 1996: Dinoflagellate cysts from marine Jurassic deposits of Denmark and Poland. American Association of Stratigraphic Palynologists Contributions Series 31, 227 pp.

Poulsen, N.E. \& Riding, J.B. 2003: The Jurassic dinoflagellate cyst zonation of Subboreal Northwest Europe. In: Ineson, J.R. \& Surlyk, F. (eds): The Jurassic of Denmark and Greenland. Geological Survey of Denmark and Greenland Bulletin 1, 115-144 (this volume).

Prosser, S. 1993: Rift-related linked depositional systems and their seismic expression. In: Williams, G.D. \& Dobb, A. (eds): Tectonics and seismic sequence stratigraphy. Geological Society Special Publication (London) 71, 35-66.

Riding, J.B. \& Thomas, J.E. 1992: Dinoflagellate cysts of the Jurassic System. In: Powell, A.J. (ed.): A stratigraphic index of dinoflagellate cysts, 7-97. British Micropalaeontological Society Publication Series. London: Chapman \& Hall.

Roberts, A.M., Price, J.D. \& Olsen, T.S. 1990: Late Jurassic halfgraben control on the siting and structure of hydrocarbon accumulations: UK/Norwegian Central Graben. In: Hardman, R.F.P. \& Brooks, J. (eds): Tectonic events responsible for Britain's oil and gas reserves. Geological Society Special Publication (London) 55, 229-257.

Rosendahl, B.R. 1987: Architecture of continental rifts with special reference to East Africa. Annual Review of Earth and Planetary Sciences 15, 445-503.

Spathopoulos, F., Doubleday, P.A. \& Hallsworth, C.R. 2000: Structural and depositional controls on the distribution of the Upper Jurassic shallow marine sandstones in the Fife and Angus fields area, Quadrants 31 \& 39, UK Central North Sea. Marine and Petroleum Geology 17, 1053-1082.

Sundsbø, G.O. \& Megson, J.B. 1993: Structural styles in the Danish Central Graben. In: Parker, J.R. (ed.): Petroleum geology of Northwest Europe: proceedings of the 4th conference,
1255-1267. London: Geological Society.

Surlyk, F. 1978: Submarine fan sedimentation along fault scarps on tilted fault blocks (Jurassic-Cretaceous boundary, East Greenland). Bulletin Grønlands Geologiske Undersøgelse 128, 108 pp.

Surlyk, F. 1989: Mid-Mesozoic syn-rift turbidite systems: controls and predictions. In: Collinson, J.D. (ed.): Correlation in hydrocarbon exploration, 231-241. London: Graham \& Trotman for the Norwegian Petroleum Society (NPF).

Surlyk, F. 1990: A Jurassic sea-level curve for East Greenland. Palaeogeography, Palaeoclimatology, Palaeoecology 78, 71-85.

Surlyk, F. \& Clemmensen, L.B. 1983: Rift propagation and eustacy as controlling factors during Jurassic inshore and shelf sedimentation in northern East Greenland. Sedimentary Geology 34, 119-143.

Underhill, J.R. \& Partington, M.A. 1993: Jurassic thermal doming and deflation in the North Sea: implications of the sequence stratigraphic evidence. In: Parker, J.R. (ed.): Petroleum geology of Northwest Europe: proceedings of the 4th conference, 337-345. London: Geological Society.

Vail, P.R., Mitchum, R.M. \& Thompson, S. 1977: Seismic stratigraphy and global changes of sea level; Part 3: relative changes of sea level from coastal onlap. In: Payton, C.E. (ed.): Seismic stratigraphy - applications to hydrocarbon exploration. American Association of Petroleum Geologists Memoir 26, 63-81.

van Adrichem Boogaert, H.A. \& Kouwe, W.F.P. (compilers) 1993: Lower and Middle Jurassic (Altena Group). In: van Adrichem Boogaert, H.A. \& Kouwe, W.F.P. (compilers): Stratigraphic nomenclature of the Netherlands, revision and update by Rijks Geologische Dienst and Netherlands Oil and Gas Exploration and Production Association. Mededelingen Rijks Geologische Dienst 50(section F), 20 pp.

Van Wagoner, J.C., Posamentier, H.W., Mitchum, R.M., Vail, P.R., Sarg, J.F., Loutit, T.S. \& Hardenbol, J. 1988: An overview of the fundamentals of sequence stratigraphy and key definitions. In: Wilgus, C.K. et al. (eds): Sea-level changes - an integrated approach. Society of Economic Paleontologists and Mineralogists Special Publication 42, 39-45.

Van Wagoner, J.C., Mitchum, R.M., Campion, K.M. \& Rahmanian, V.D. 1990: Siliciclastic sequence stratigraphy in well logs, cores and outcrops: concepts for high-resolution correlation of time and facies. American Association of Petroleum Geologists Methods in Exploration Series 7, 55 pp.

Vollset, J. \& Doré, A.G. (eds) 1984: A revised Triassic and Jurassic lithostratigraphic nomenclature for the Norwegian North Sea. Norwegian Petroleum Directorate Bulletin 3, 53 pp.

Whiteman, A.J., Rees, G., Naylor, D. \& Pegrum, R.M. 1975: North Sea troughs and plate tectonics. Norges Geologiske Undersøkelse 316, 137-161.

Ziegler, P.A. 1982: Geological atlas of western and central Europe, 130 pp. The Hague: Elsevier for Shell Internationale Petroleum Maatschappij.

Ziegler, P.A. 1990: Tectonic and palaeogeographic development of the North Sea rift system. In: Blundell, D.J. \& Gibbs, A.D. (eds): Tectonic evolution of the North Sea rifts, 1-36. Oxford: Clarendon Press. 


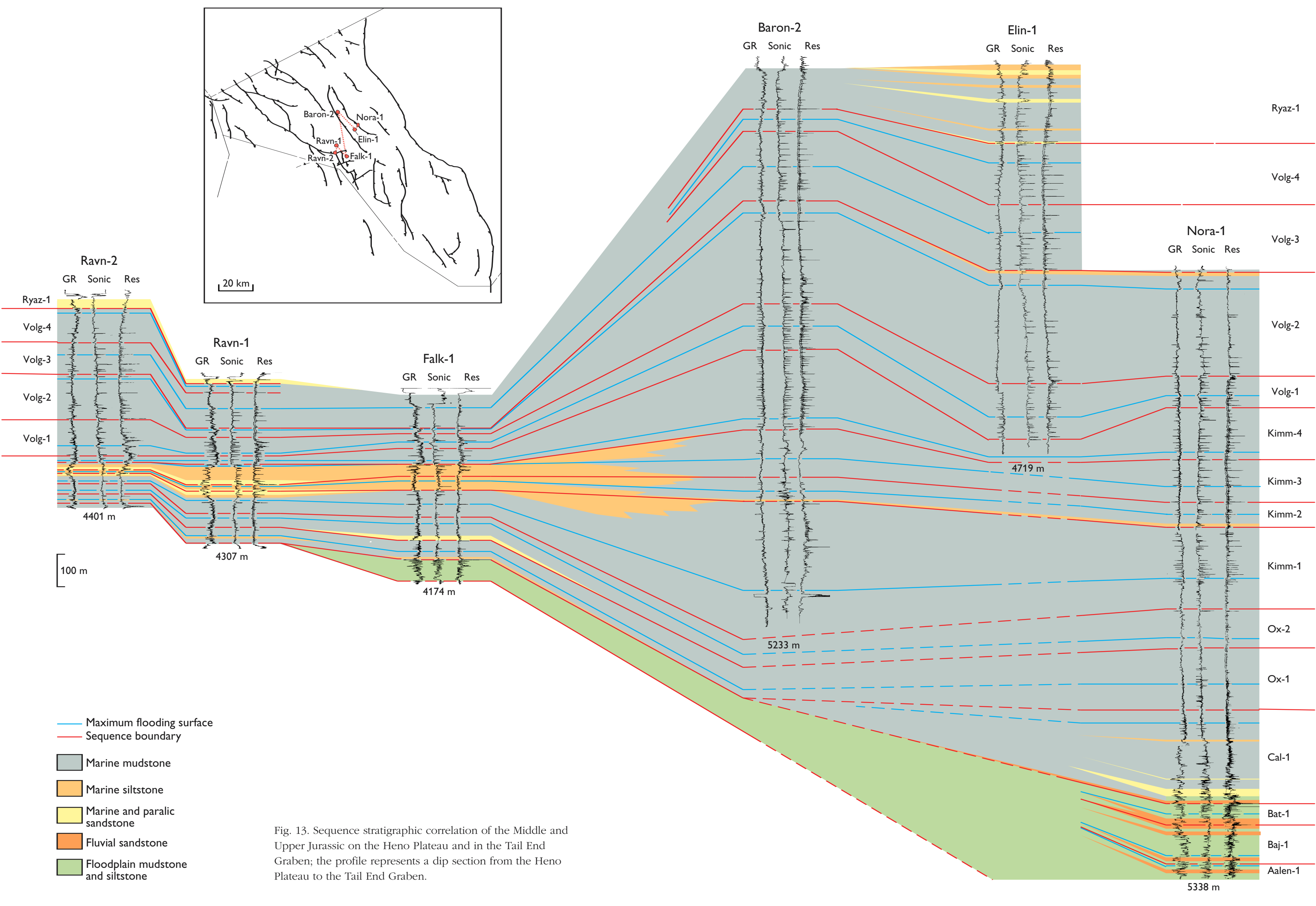




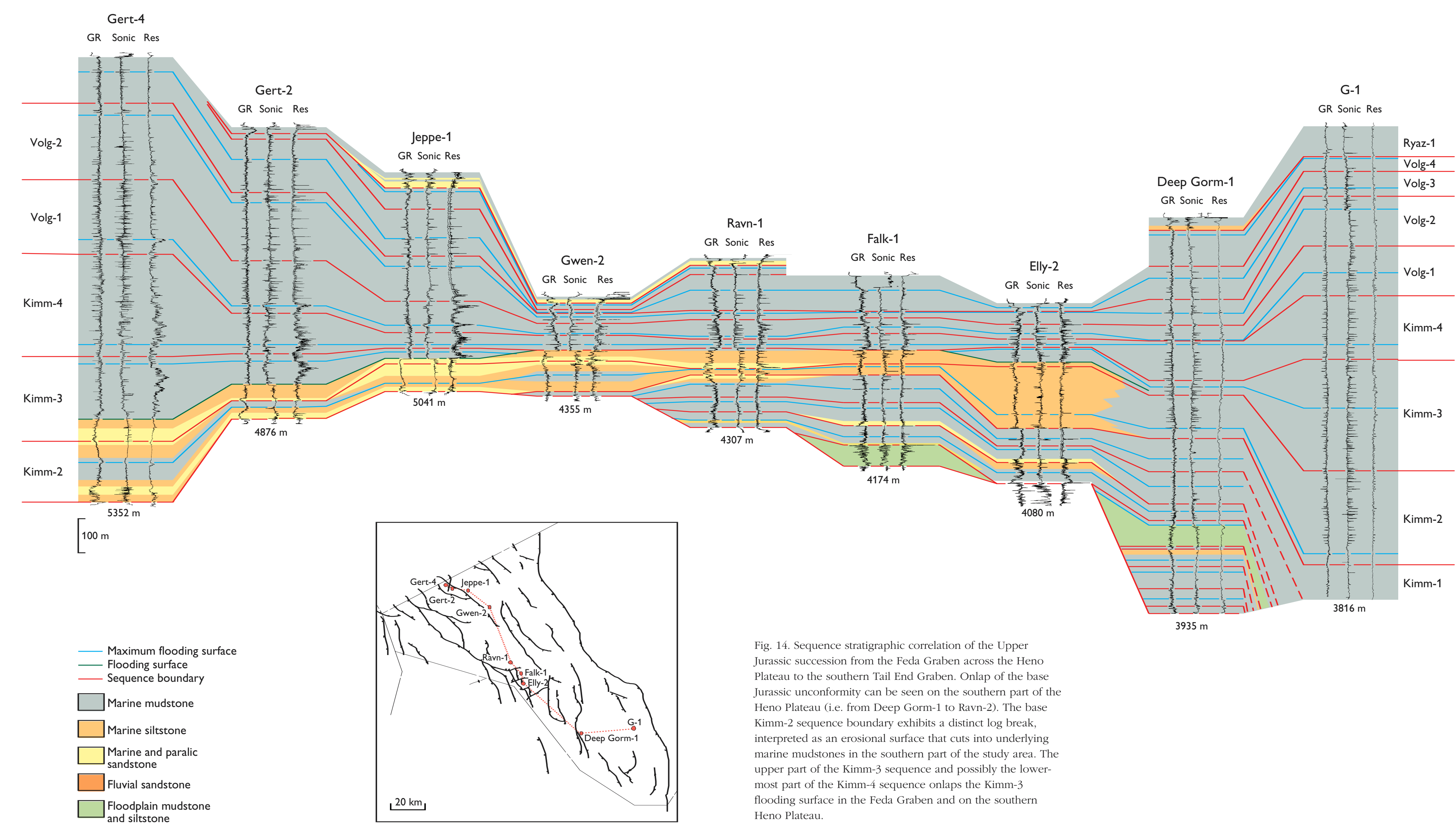




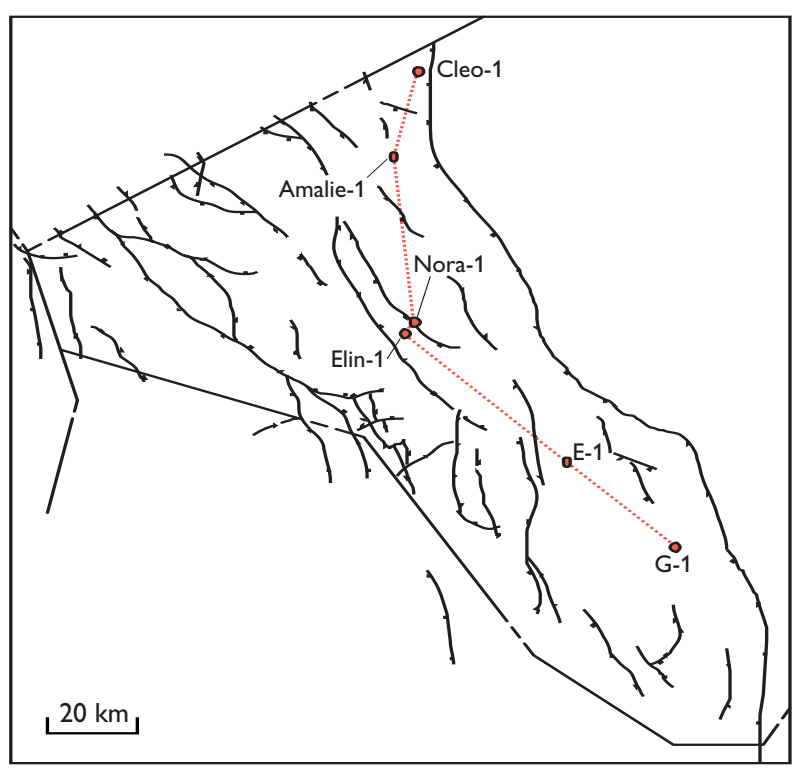

Maximum flooding surface

Sequence boundary

Marine mudstone

$\square$ Marine siltstone

$\square$ Mandstone

$\square$ Fluvial sandstone

$\square$ Floodplain mudstone

Foodplain muds
and siltstone

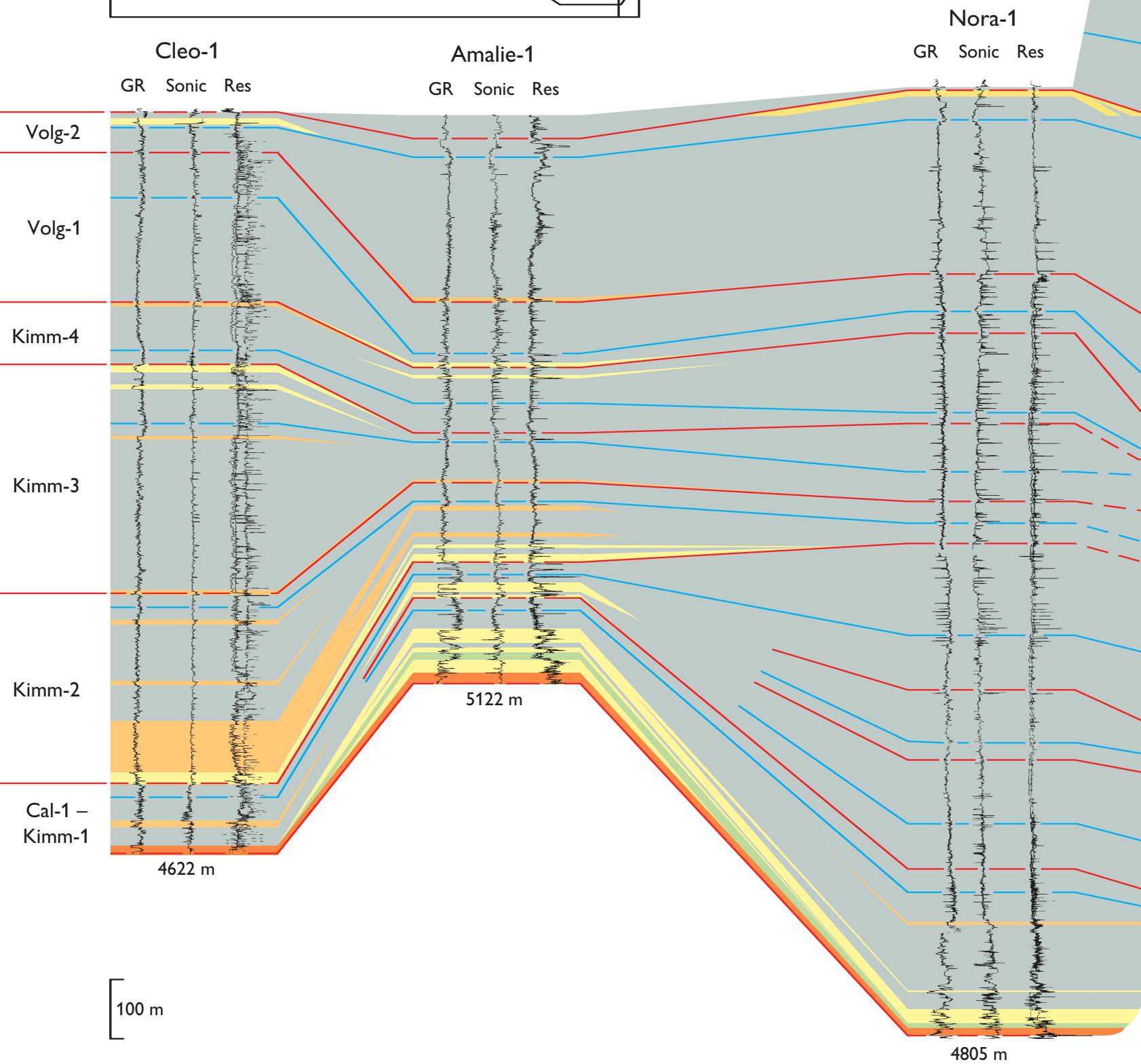

$4805 \mathrm{~m}$

\section{Elin-1}

GR Sonic Res

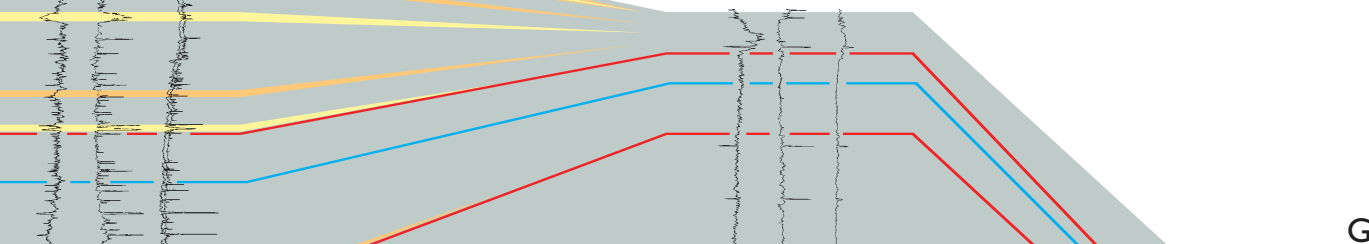

G-1

GR Sonic Res

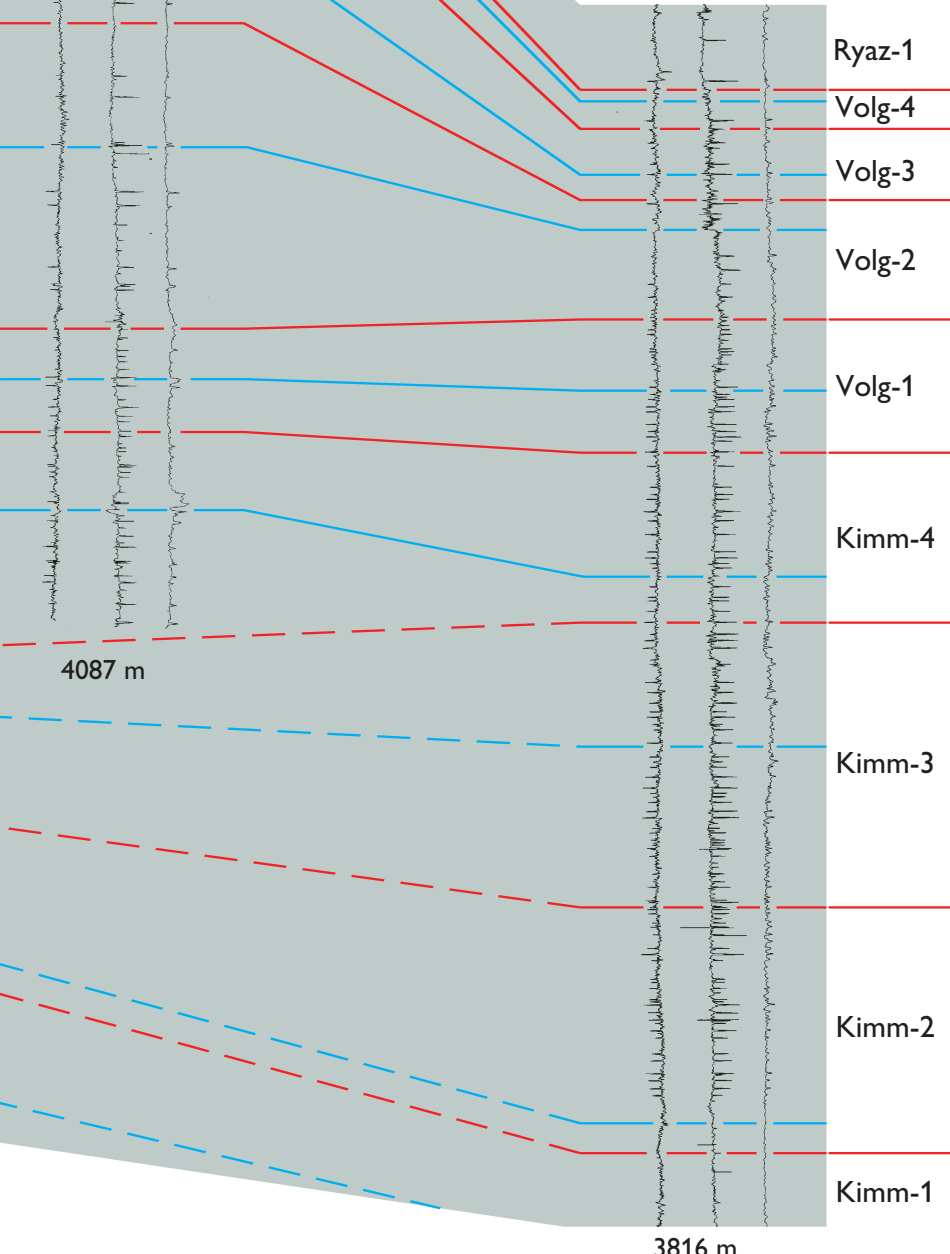

Fig. 16. Sequence stratigraphic correlation of the Upper Jurassic

succession in the Tail End Graben; the profile is parallel to the basin 
Kim-1

GR Sonic Res

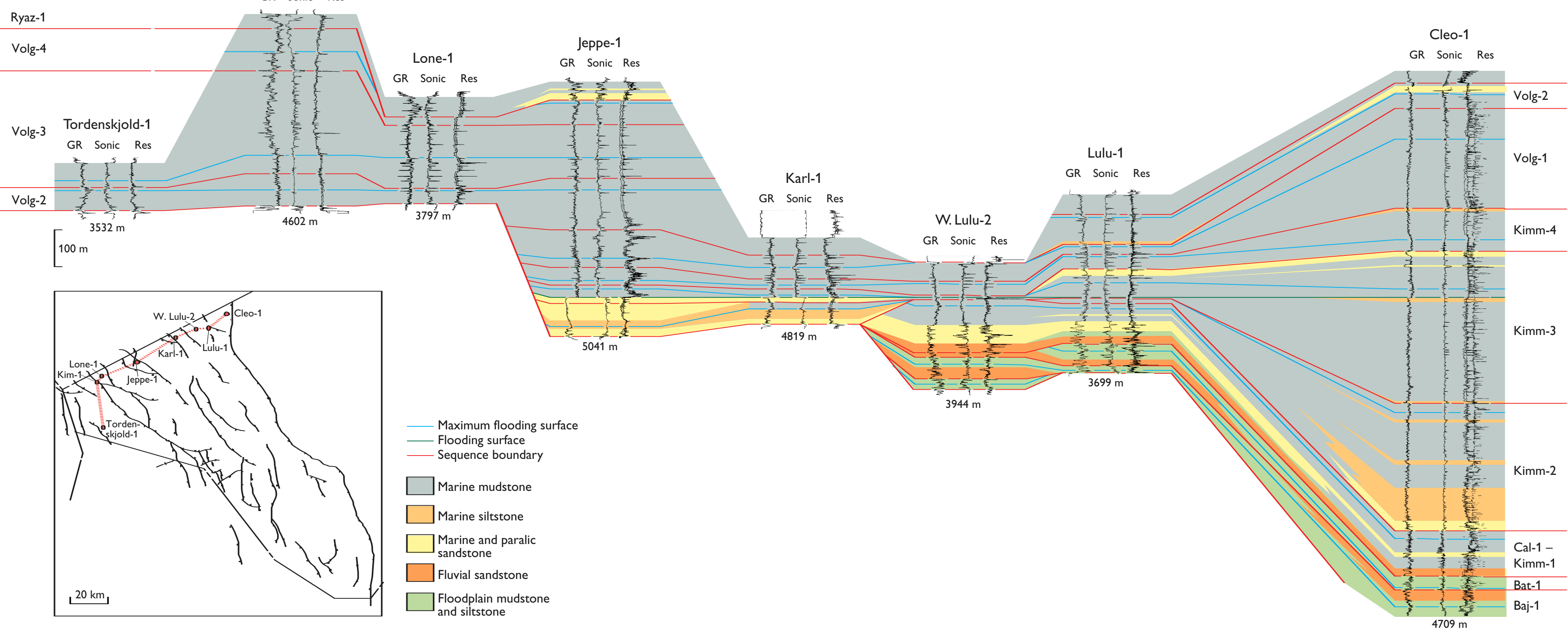

Fig. 17. Sequence stratigraphic correlation of the Upper Jurassic in the northern part of the

Danish Central Graben. The profile is perpendicular to the main structural elements from the

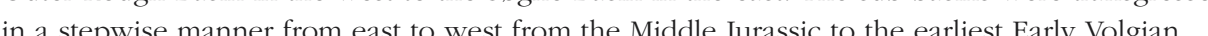

